Pacific Northwest

National Laboratory

Operated by Battelle for the

U.S. Department of Energy

\title{
An Anatomy of China's Energy Insecurity and Its Strategies
}

\author{
B. Kong
}

October 2005

Prepared for the U.S. Department of Energy

under Contract DE-AC05-76RL01830

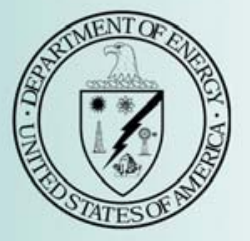




\title{
DISCLAIMER
}

This report was prepared as an account of work sponsored by an agency of the United States Government. Neither the United States Government nor any agency thereof, nor Battelle Memorial Institute, nor any of their employees, makes any warranty, express or implied, or assumes any legal liability or responsibility for the accuracy, completeness, or usefulness of any information, apparatus, product, or process disclosed, or represents that its use would not infringe privately owned rights. Reference herein to any specific commercial product, process, or service by trade name, trademark, manufacturer, or otherwise does not necessarily constitute or imply its endorsement, recommendation, or favoring by the United States Government or any agency thereof, or Battelle Memorial Institute. The views and opinions of authors expressed herein do not necessarily state or reflect those of the United States Government or any agency thereof.

\author{
PACIFIC NORTHWEST NATIONAL LABORATORY \\ operated by \\ BATTELLE \\ for the \\ UNITED STATES DEPARTMENT OF ENERGY \\ under Contract DE-AC05-76RL01830
}

Printed in the United States of America

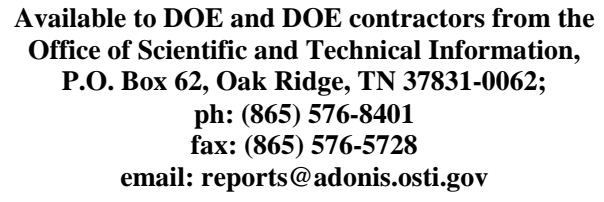

Available to the public from the National Technical Information Service, U.S. Department of Commerce, 5285 Port Royal Rd., Springfield, VA 22161 ph: (800) 553-6847 fax: (703) 605-6900 email: orders@ntis.fedworld.gov online ordering: http://www.ntis.gov/ordering.htm 


\section{Summary}

Recent power shortages, environmental degradation, vulnerability to various oil supply and price shocks, and the lack of an energy policy making capacity constitute four dimensions of China's energy insecurity. Structurally and fundamentally, however, China's energy insecurity largely originates from the constrained availability, questionable reliability, and uncertain affordability of its oil supplies. The country's rapid industrialization and urbanization, together with demand for infrastructure and the increasing popularity of automobiles, requires a lot of energy. Yet, China consumes energy both intensively and inefficiently, placing pressure on its domestic and the international energy markets, and threatening the environmental well-being of China and its neighbors.

China's risk aversion and poor energy policy making system further magnify its perceptions of the low availability, reliability and affordability of oil imports, which further compound its sense of energy insecurity. Distrustful of the market, and suspicious of other major energy players in the international market, the Chinese leadership relies on the state-centered approach, or economic nationalism, rather than a market approach to enhance its energy security. Moreover, the country lacks not only an energy policy making system that can make and implement sound energy policies but also an energy market that relies on market prices to allocate energy resources efficiently. As a result of this domestic failure, China has pushed its national flagship companies to undertake a global scavenger hunt for energy while muddling along a messy road of energy reform at home. Setbacks in acquiring new sources of oil have supported the Chinese leadership's belief that international oil is not subject to free market forces and that China's access to international oil is not guaranteed through the market. China's problems in the international energy market are also perceived as evidence of attempts by other major players in the international system to prevent China from exerting international influence. As a result, China's leadership is convinced that China should focus on areas where western capital is not heavily concentrated or where western influences are weak. With the recent revaluation of Chinese currency and its growing economy, China has both the wherewithal and appetite to acquire more oil assets abroad.

Both China and the United States stand at a critical juncture of history where China's rise depends on reliable energy supplies which it increasingly imports from abroad and where the growing wealth of the United States is increasingly dependent upon China's success. If China does not have energy security its 1.3 billion fuel-starved people may prevent the rest of the world from achieving energy security. 
This report was prepared by Bo Kong, a doctoral candidate at the Johns Hopkins School of Advanced International Studies, while working as a fellow at the Pacific Northwest Center for Global Security during the summer of 2005. He prepared this manuscript for use as the seminal document for a joint conference prepared by the Center and the National Bureau of Asia research on "China's Search for Energy Security." The conference was held at the National War College in September 2005. Mr. Kong's research was presented at that workshop and is now being made available to the public as a Center paper.

All translations of Chinese-language references were done by the author. 


\section{Contents}

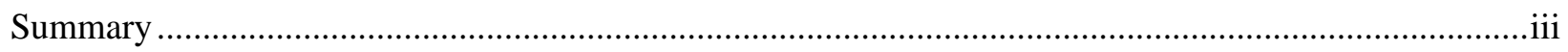

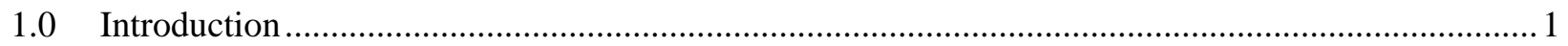

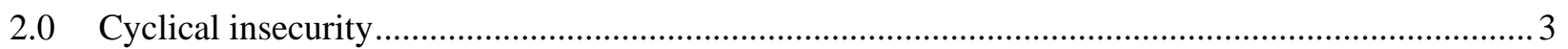

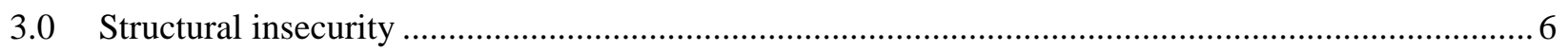

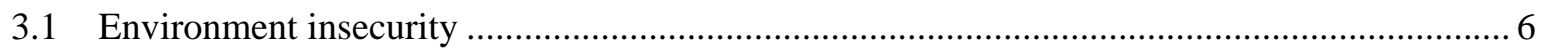

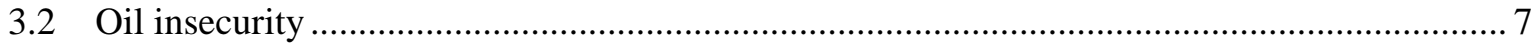

3.2.1 What are the sources of China’s oil insecurity? ........................................................ 12

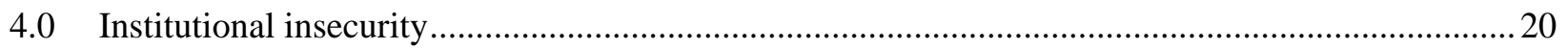

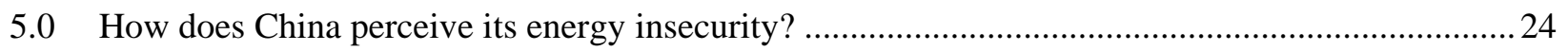

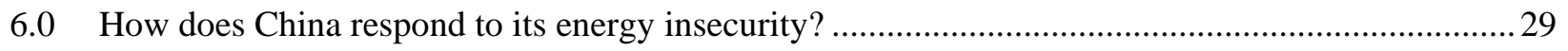

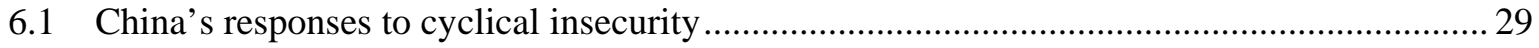

6.2 China’s responses to environmental insecurity …................................................................ 32

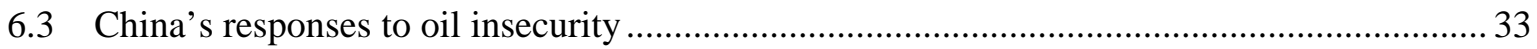

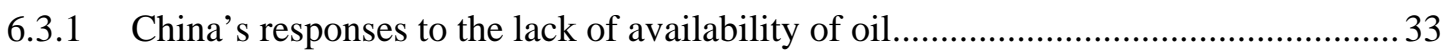

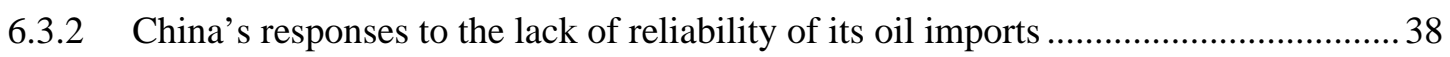

6.3.3 China’s responses to the affordability its oil imports ............................................... 43

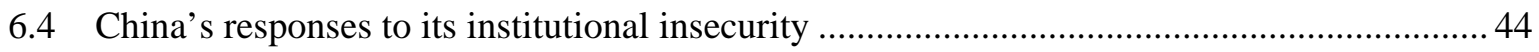

7.0 An assessment of China’s responses to energy insecurity …........................................................ 47

8.0 Why is the United States concerned about China’s search for energy security? ............................ 50

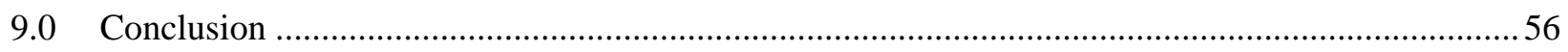

\section{Figures}

Figure 1. China's energy production and consumption ....................................................................... 1

Figure 2. Framework of China’s energy insecurity ........................................................................... 2

Figure 3. Number of Provinces and Municipalities affected by Power Shortages, 2002-2005 ................... 3

Figure 5. China’s oil production and consumption, 1992-2004............................................................. 8

Figure 6. China's dependency on foreign oil ...................................................................................... 9

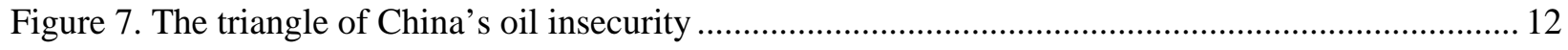

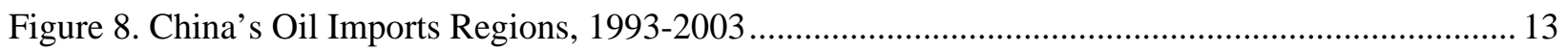




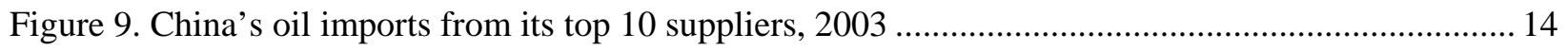

Figure 10. Map of shipping lanes (Source: Economist.com) …........................................................... 17

Figure 11. Number of piracy attacks in Strait of Malacca, 1999-2004 …................................................. 18

Figure 12. Chinese expenditures on oil imports and share of total imports............................................. 19

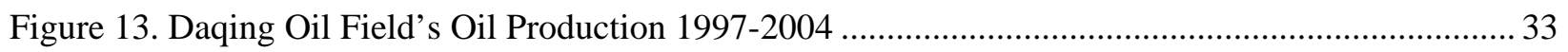

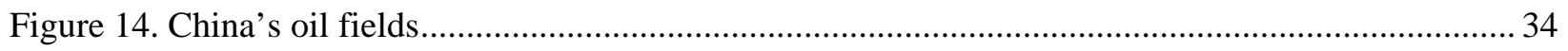

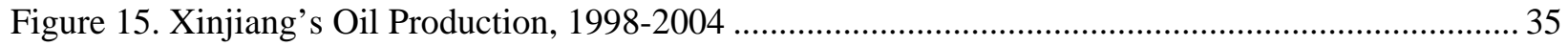

Figure 16. Map of China’s off shore oil and gas fields............................................................................ 36

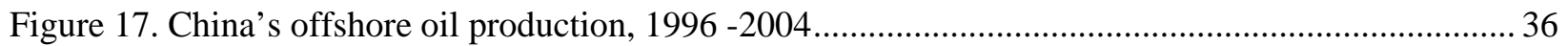

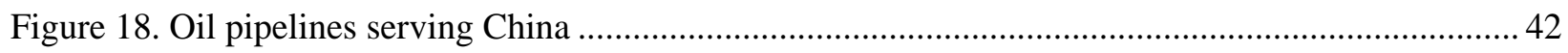

Figure 19. Summary of the regulatory structure of state energy enterprises in China, 2003 to present ..... 45

Figure 20. Imports of oil and oil product by non-state owned oil companies since 2002 in China............ 46

Figure 21. Gas field boundaries in the East China Sea (Source: www.rigzone.com ).............................. 51

\section{Tables}

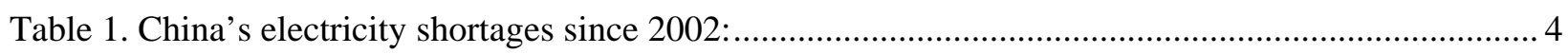

Table 2. China's medium- and long-term dependence on foreign gas.................................................... 7

Table 3. China’s imports of oil and oil products since 1993 (in 10,000 tons) .......................................... 9

Table 4. Forecasts of China's growing dependency on foreign oil....................................................... 11

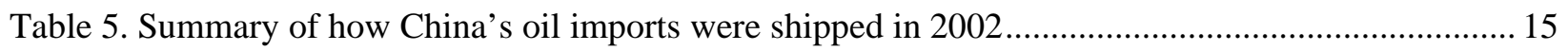

Table 6. Summary of how China's oil imports from different sources were shipped in 2002 .................. 16

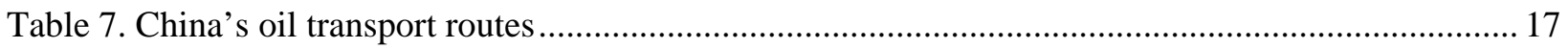

Table 8. Summary of growth of China's electricity consumption and investment, 2000-2003: ............... 21

Table 9. Summary of China’s multi-layered energy decision making system.......................................... 22

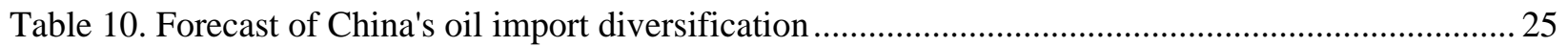

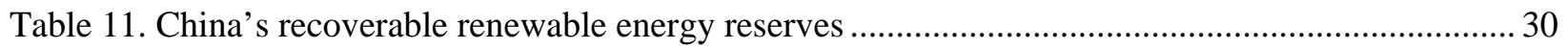

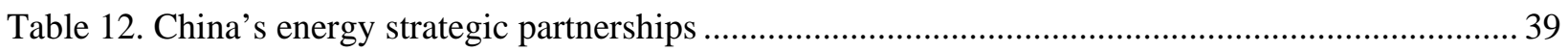

Table 13. CNPC's overseas oil reserves and production, 2001-2204 ...................................................... 40

Table 14. Summary of China's responses to its energy insecurity ........................................................... 55 


\subsection{Introduction}

Overall, China maintains a high degree of energy self-reliance. Between 1978 and 2004, on average $97.4 \%$ of its total energy demand was satisfied at home, with only a 4\% energy shortage in 2004 at the national level ${ }^{1}$ (Fig. 1). Does this high level self-sufficiency mean that the country enjoys energy security? Four yardsticks help us make the judgment. ${ }^{2}$ Does the country have a sufficient energy supply? Is its energy supply reliable? Is its energy priced in a way that is commensurate with its purchasing power? Finally but not the least, does its energy consumption harm its environment? In other words, energy security in China, and for that matter any country elsewhere, is multi-dimensional. Therefore, focusing only on the overall energy balance can be misleading.

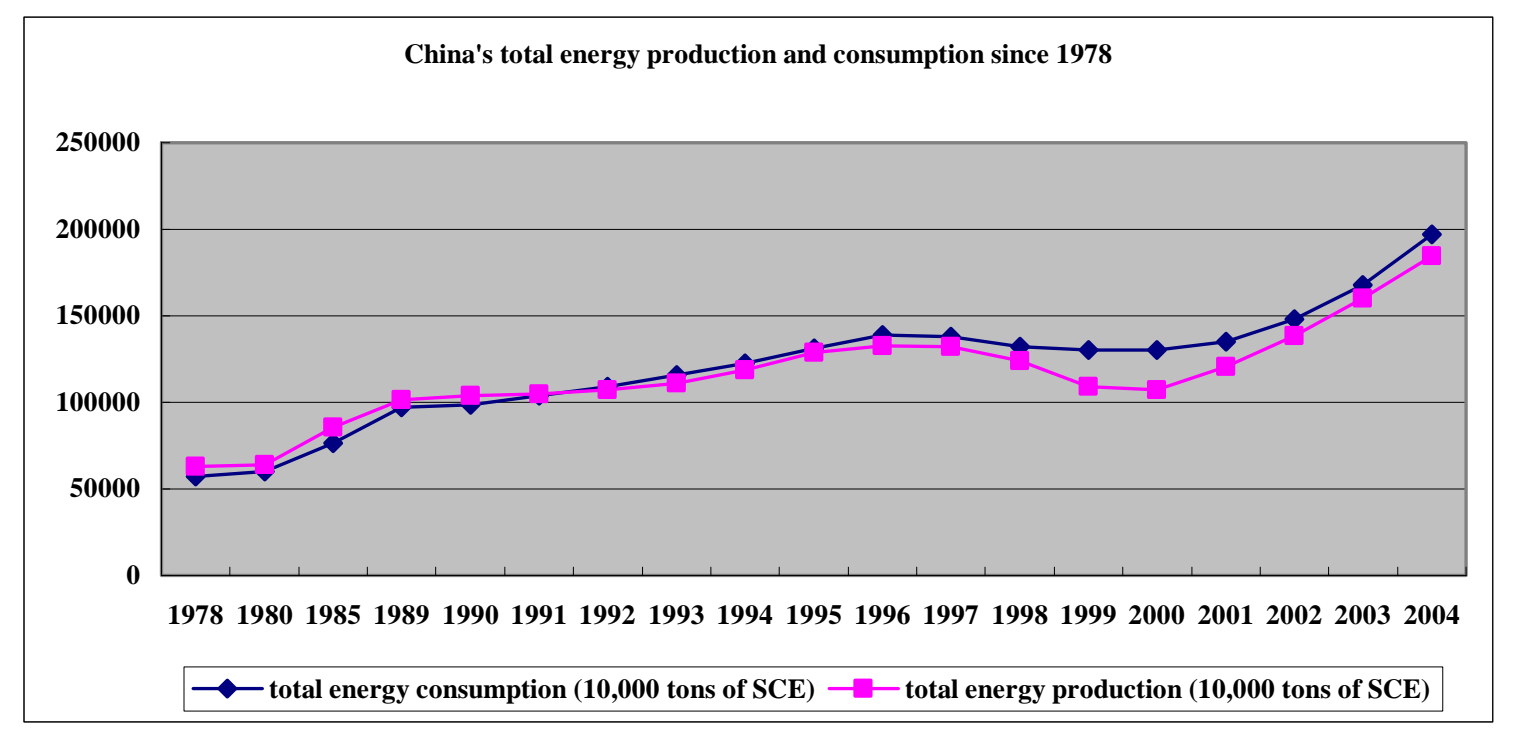

Figure 1. China's energy production and consumption ${ }^{3}$

In the minds of Chinese leaders, energy has remained a high priority, particularly during China's pursuit of economic prowess. Recognition of China's multiplying energy demand has directed new attention to its developing problem of energy security. China's energy insecurity can be assessed in terms of actual cyclical, structural and institutional insecurities, and in terms of perceived insecurity of energy availability, reliability and affordability (Fig. 2). It is critical to consider both actual and perceived insecurity because the former speaks to the magnitude of China's energy insecurity and the latter points to the country's policy response to different sources of insecurity. Specifically, perceived insecurity indicates the motivations behind China's proposed solutions and China's response strategy. Understanding how these solutions address the actual security issues will clarify the implications of current policies while highlighting the need for any adjustments in future strategies. First, let us consider

\footnotetext{
${ }^{1}$ China Statistical Yearbook, No.23, China Statistics Press, 2004.

${ }^{2}$ Similarly, Daniel Yergin defined energy security as the capability to assure adequate, reliable energy supplies at reasonable prices in ways that do not jeopardize its major national values and objectives. See Daniel Yergin, “Energy Security in the 1990s,” Foreign Affairs, Vol. 67(1), 1998, p.111.

${ }^{3}$ China Statistical Yearbook, No.23, China Statistics Press, 2004.
} 
how China's actual energy insecurities can be divided into cyclical, structural and institutional components.

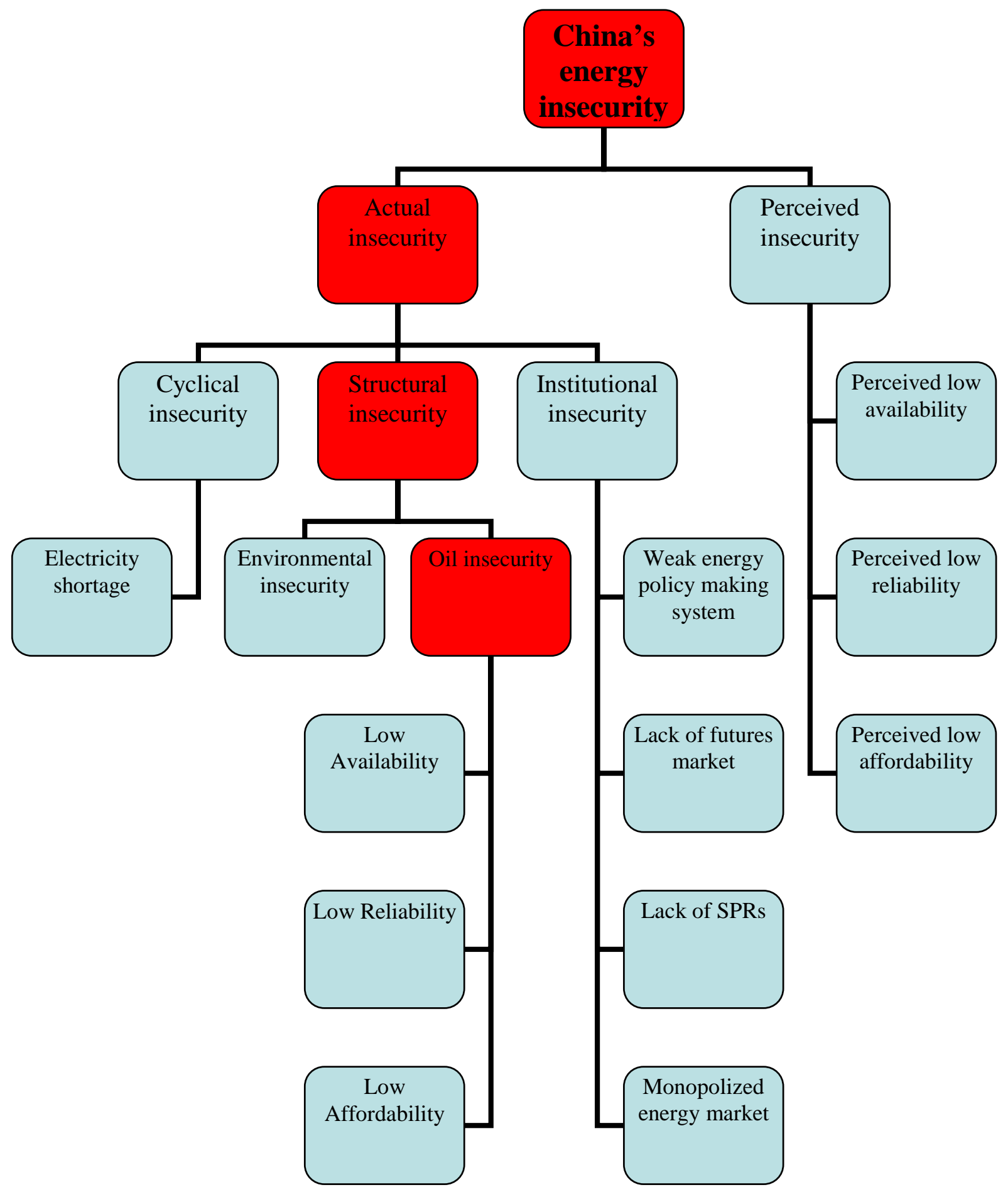

Figure 2. Framework of China's energy insecurity 


\subsection{Cyclical insecurity}

Indeed, counteracting the claim that China has enjoyed a high level of energy self-sufficiency are the realities of regular blackouts or brownouts that have swept through the country from late 2002. In fact, these electricity shortages have worsened since they first broke out, with the number of places having to ration power averaging above two thirds of China's 32 provinces and cities in the past three years (Fig. 3). Furthermore, the gap of power supply has widened, with the shortages in 2003 more than doubling those of the previous year and only leveling off slightly in 2004 (Table 1). In short, power shortages will continue to plague the Chinese economy until 2006 when supply can meet the demand.

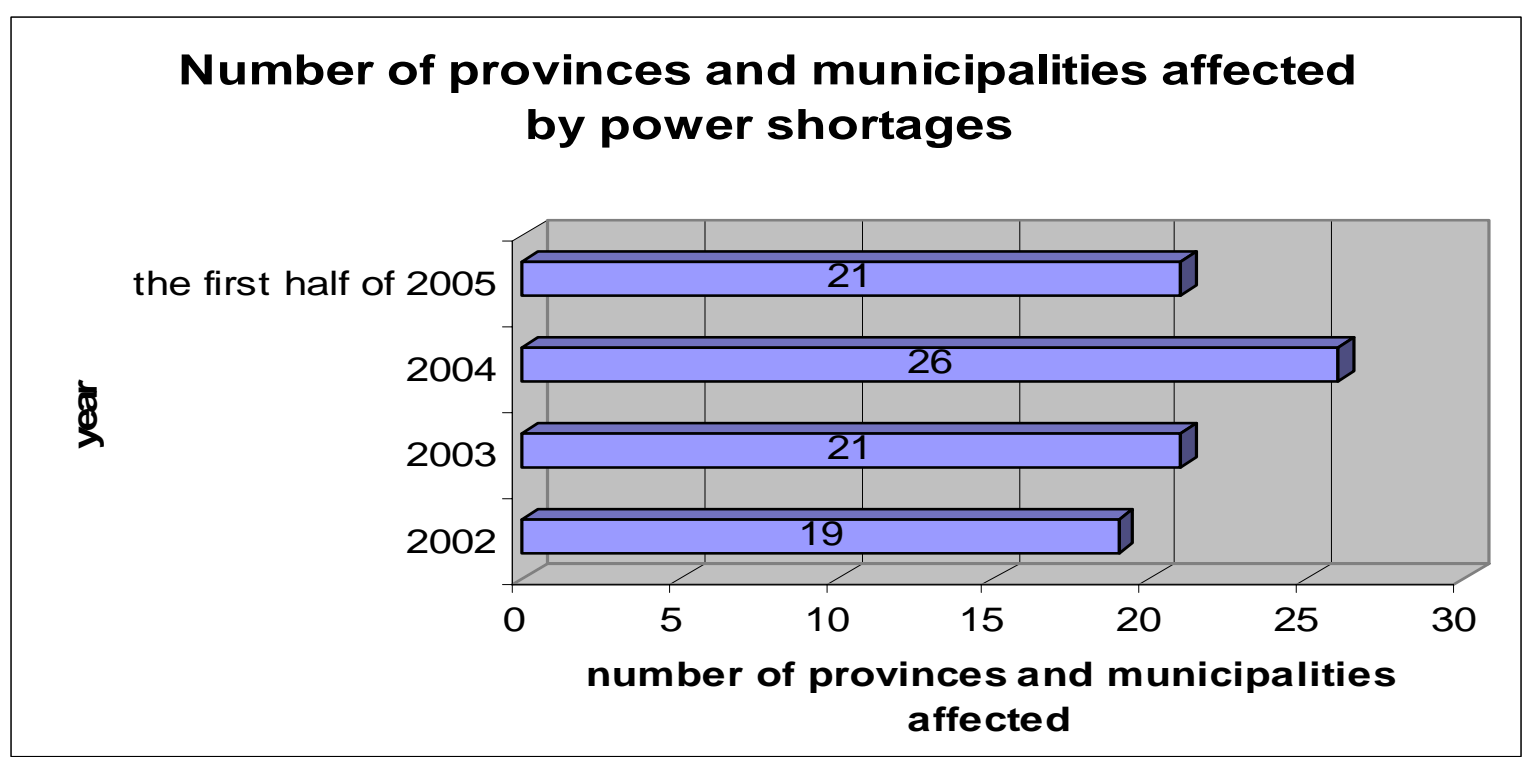

Figure 3. Number of Provinces and Municipalities affected by Power Shortages, 2002-2005

As a result of this latest round of power shortages, ${ }^{4}$ Chinese people's lives and the Chinese economy have both suffered. In fact, millions of people, particularly those in eastern and southern China, have to live without electricity in scorching hot summers during the daytime and sometimes even the evening time as well. In one of the hardest hit cities, Changsha, the capital city of Mao Zedong's home region, Hunan Province (Fig. 4), residents have to spend one day out of every four without power. Similarly, thousands of factories and enterprises in economically dynamic areas are forced to sit idle during peak hours. In Zhejiang Province, the fastest growing economy in China, more than half of its total private enterprises were cut off power in the first half of 2004 for 11.32 days per month on average. ${ }^{5}$ As a result,

\footnotetext{
${ }^{4}$ The last power shortage hit China in 1969 and did not end until 1998.

5 “2004 nian zhongguo da quedian: sanfen tianzan, qifen renhuo” (Electricity shortage in 2004: 30\% natural disasters and 70\% human errors), Xinhua News Agency, Online Edition, available at http://news.xinhuanet.com/stock/2004-12/22/content_2366867.htm, December 22 2004, accessed August 19, 2005.
} 
Table 1. China's electricity shortages since $2002^{6}$ :

\begin{tabular}{|c|c|}
\hline & Electricity shortage (million kilowatt hours) \\
\hline 2002 & 20.35 \\
\hline 2003 & 44.85 \\
\hline 2004 & 30 \\
\hline 2005 & $15 \sim 20$ \\
\hline 2006 & 0 \\
\hline
\end{tabular}

economic losses are gigantic. According to the official estimate, one kilowatt hour in Zhejiang province generates output worth 22.44 yuan (about \$3). Hence, a shortage of more than 7.5 billion kilowatt hours in that province alone amounted to economic losses worth 10 billion yuan (\$1.2 billion) in $2004 .^{7}$ At the national level, for each kilowatt-hour power plants come up short, the economy loses six yuan, or just more than 70 cents. Marrying that figure with the State Electricity Regulatory Commission's estimate that the country fell short by 60 billion kilowatt hours in 2004, it cost the economy 360 billion yuan (\$43 billion). ${ }^{8}$ In total, economic losses over the past five years resulting from power shortages since 2000 were estimated to be over 1 trillion yuan ${ }^{9}$ or 120.8 billion dollars, which is equivalent to $10 \%$ of China's GDP in the year 2001.

Moreover, power shortages also exacerbate other bottlenecks in China's energy supply. As more than $80 \%$ of China's electricity is generated by coal and $75 \%$ of its power plants run on coal, power shortages immediately lead to a surge of demand for coal. However, approximately three quarters of the country's demand for energy is concentrated in eastern and central China whereas coal is scattered around the north and the west. As a result, the sudden hike in demand for coal overwhelms the railway system, with more than $40 \%$ of its cargo shipping capacity dedicated to coal. ${ }^{10}$ According to the Ministry of Railways, daily demand for railway cars to ship coal hovers around 29,000 to 30,000 but only 10,000 can be allocated. ${ }^{11}$

As a result, there emerged a gap of coal supply around 100 million tons in 2004 across the country, which in turn resulted in price spikes of coal up to $80 \%$ in the same year. On the other hand, to generate electricity many local governments and enterprises rushed to buy small diesel or gas-fired power generators to keep up the economy or production, which further drove up demand for oil and gas and

${ }^{6}$ Ibid.

${ }^{7}$ Ibid.

${ }^{8}$ Official estimate cited in Matt Pottinger, “China Sweats out Power Shortages,” Wall Street Journal, Eastern Edition, August 19 2005, p. A11.

9 “2004 nian zhongguo da quedian: sanfen tianzan, qifen renhuo" (Electricity shortage in 2004: 30\% natural disasters and 70\% human errors), Xinhua News Agency, Online Edition, available at http://news.xinhuanet.com/stock/2004-12/22/content_2366867.htm, December 22 2004, accessed August 19, 2005.

${ }^{10}$ Wang Qingyi, “Zhongguo yu shijie nengyuan shuju” ("Data on China and the World's Energy”), Meitan jingji yanjiu (Journal of Coal Economics Study), Vol.2, 2004, p.74.

${ }^{11}$ Zhang Xudong, Tan Hao, and Ding Xiguo, “Zhongguo nengyuan anquan weiji, mei dian yun nengfou zhicheng GDP 8\% zengsu” (China’s energy security crisis: can coal, electricity, and shipment support 8\% GDP growth?), China Oil News, available at http://www.oilnews.com.cn/gb/misc/2005-03/15/content_607966.htm, March 15 2005, accessed August 19, 2005. 


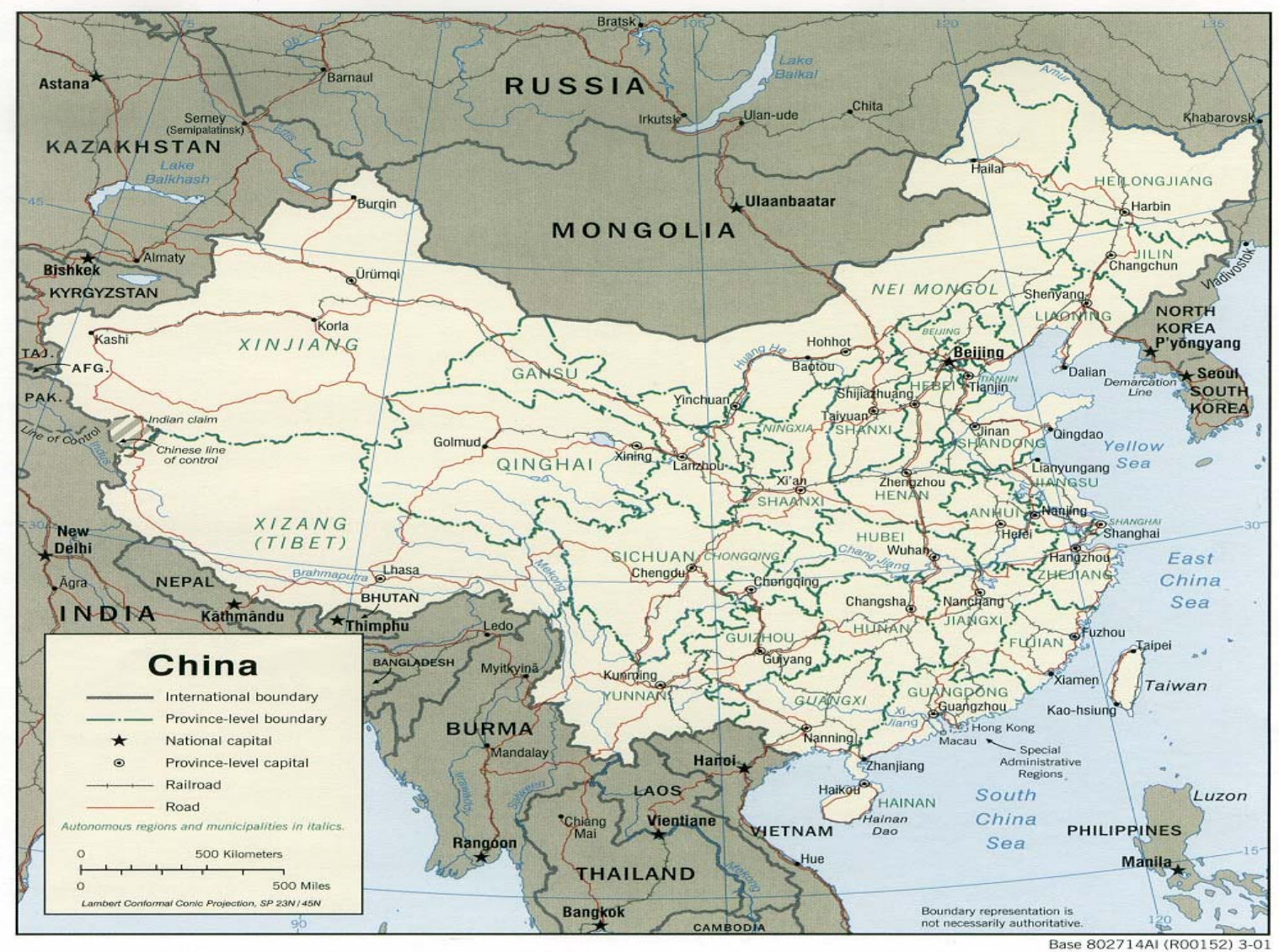

Figure 4. Map of China (Source: University of Texas Perry-Castañeda Library Map Collection)

pushed up prices of those fuels. As a result, electricity shortages not only contribute to shortages of coal, oil, and gas but also cripple the transportation system, thereby creating the image of an overall energy crisis. Hence, the magnitude and scale of power shortages and their resultant economic impacts undoubtedly qualify power shortages as one important element of China's energy insecurity.

Power shortages, however, only constitute China's cyclical energy insecurity in that they are seasonal, regional, sector specific, and temporary. Specifically, the power crunch usually occurs in China during the summer time and its traditional lunar New Year in February. Even during these two seasons, power shortages happen more often during peak hours. In terms of regional distribution, power shortages hit east coast, Central China, and South China particularly hard, whereas the northeast, northwest, and southwest are largely spared. In terms of sectors, energy-intensive sectors such as iron, steel, cement, construction material, and aluminum are more negatively affected than other sectors. Moreover, these power shortages can be bridged rather quickly once the government accelerates power investments. In fact, investments in the past three years have been catching up very fast, with 11.65 million kilowatt, 30 million kilowatts, and 50.55 million kilowatts of installed capacity being added in 2002, 2003, and 2004 respectively. ${ }^{12}$ The total

\footnotetext{
12 Data are drawn from 2002, 2003 and 2004 Annual Statistical Survey by National Bureau of Statistics of China, Internet version, available at http://www.stats.gov.cn/tjgb/ndtjgb/qgndtjgb/t20030228_69102.htm, http://www.stats.gov.cn/tjgb/ndtjgb/qgndtjgb/t20040226_402131958.htm, http://www.stats.gov.cn/tjgb/ndtjgb/qgndtjgb/t20050228_402231854.htm, accessed August 19, 2005.
} 
added capacity in the last three years is more than two times California's entire electricity production in 2004. ${ }^{13}$ Moreover, many investments are added at the local government level, which are not approved by National Development and Reform Commission (NDRC), the central planning body in charge of China's energy planning. Therefore, actual increased capacity could be more. As a result of this ill-coordinated growth in power investment, China is almost bound to experience power oversupply very soon.

According to an official from China Machinery Industry Federation, the oversupply of power generating equipment will materialize in 2007. ${ }^{14}$ Similarly, Zhang Guobao, a vice-minister at NDRC, even suggested an overcapacity of power in some areas in the second half of $2006 .{ }^{15}$

\subsection{Structural insecurity}

\subsection{Environment insecurity}

In addition to the cyclical energy insecurity, structural insecurity looms large in China's perception of its energy insecurity as well, which to a large extent boils down to oil insecurity. In China, coal dominates energy consumption, accounting for two thirds of the total. However, too much coal usage has threatened to wreck the country's sustainable economic development. An overdependence on coal consumption makes China the largest emitter of sulfur dioxide and the second largest emitter of carbon dioxide in the world next to the United States. ${ }^{16}$ Moreover, 16 of the world's 20 most polluted cities are in China and estimates suggest that 300,000 people a year die prematurely from respiratory diseases. ${ }^{17}$ According to a 1997 World Bank study, air and water pollution damages, especially the damage of fine airborne particulates to human health, have been estimated to be at least US \$54 billion annually or nearly 8 per cent of GDP in $1995 .{ }^{18}$ Factoring in the environmental costs of its economic development, China's economy only grew $2.5 \%$ instead of $10.5 \%$ that year. According to some Chinese estimates, pollution, if left unaddressed, by 2020 will affect 490 million people, or one third of China's total population, and lead to a death toll around 550,000 people, costing the economy at least 41 billion yuan (about $\$ 5$ billion). ${ }^{19}$ Hence, too much coal consumption gives rise to China's environment insecurity, which is another aspect of China's energy insecurity.

${ }^{13}$ According to California Electricity Commission, California's total electricity production in 2004 was 289359 gigawatt hours, see http://www.energy.ca.gov/electricity/electricity_generation.html. Assuming a capacity factor of $75 \%$, China's newly installed power plants can generate 608520 gigawatt hours in the last three years.

14 "Power-Generators Sector Warned of Oversupply in 2008," Xinhua News Agency, Online Edition, available at http://news.xinhuanet.com/english/2005-07/27/content_3274210.html, July 27 2005, accessed August 10, 2005.

${ }^{15}$ An interview with Zhang Guobang on state television cited in Richard McGregor, "China Heads for Power Glut in Late 2006 Plant Construction,” Financial Times, London Edition 1, August 10 2005, p. 6.

16 "Zhongguo nengyuan fazhan zhanlue yu zhengce yanjiu baogao" ("Report on China’s Energy Development Strategy and Policy”), Project team of Report on China’s Energy Development Strategy and Policy, Jingji cankao yanjiu (Economic Research and Reference), Vol. 83, 2004, p. 7.

${ }^{17}$ Based on a 1998 World Bank report cited in “China's Environment: A Great Wall of Waste,” The Economist, August 19 2005, Online Edition, available at http://www.economist.com/business/displayStory.cfm?story_id=3104453, accessed August 22, 2005.

18 "Protecting the Environment," Chapter 6 in China 2020: Development Challenges in the New Century (Washington DC: the World Bank, 1997).

19 “Caijing Fengmian wenzhang: zhongguo nengyuan cong weiji dao xinzheng,” “"Caijing Cover Article: China’s Energy, From Crisis to New Administration), Xinhua News Agency, Online Edition, available at http://news.xinhuanet.com/newscenter/2003-12/08/content_1219873.htm, accessed August 112005. 


\subsection{Oil insecurity}

Alarmed by the colossal environmental cost of coal consumption and its threat to China's sustainable development, the Chinese government has started to cut down on coal consumption. As a result, the percentage of coal consumption dropped from 76\% in the early 1990s to 65\% in 2001 before climbing up again to $67.1 \%$ in 2003 when power shortages struck China. ${ }^{20}$ Meanwhile, oil, gas, hydroelectric, and nuclear power filled in the $11 \%$ decline in coal consumption, with oil consumption growing by $7.4 \%$, hydroelectric power $2.7 \%$, and gas and nuclear power less than $1 \%$ from 1990 to $2002 .^{21}$

The threat to China's energy security does not stem from the switch from coal to hydroelectric power or nuclear power. After all, China's hydroelectric exploitation potential ranks the first in the world, with reserves standing at 700 million kilowatts, accounting for $40 \%$ of the country's total conventional sources of energy. ${ }^{22}$ Similarly, an addition of 30 nuclear power plants over the next 15 years will allow China to expand nuclear power capacity, doubling its share of total energy consumption to $4 \%$ by $2020 .{ }^{23}$ Neither does the switch to natural gas create any immediate security concerns. While China only possesses $1.2 \%$ of world total natural gas reserves, its reserve/production ratio stands at 54.7, meaning at the current pace of production its gas reserves would last about 55 years. ${ }^{24}$ Furthermore, China is still self-reliant on natural gas though as demand grows China will increasingly depend on foreign gas. However, according to various estimates, China's dependence on foreign gas will only grow to $10 \%$ by 2010 and $17 \%$ or higher by 2020 (Table 2). Hence, gas security remains a medium- or long-term energy security issue. Rather, it is the supply of more oil, which is considered a strategic commodity due to its importance in economic development and its military utility, that bears the brunt of substitutes for coal and constitutes the principal element of China's structural energy insecurity at present.

Table 2. China's medium- and long-term dependence on foreign gas

\begin{tabular}{|l|c|c|c|c|}
\hline & $\mathbf{2 0 1 0}$ & $\mathbf{2 0 1 5}$ & $\mathbf{2 0 2 0}$ & $\mathbf{2 0 5 0}$ \\
\hline International Energy Agency (2002) $^{25}$ & $9.8 \%$ & & $17.4 \%$ & \\
\hline Liu Lili, CNPC $^{26}$ & $10 \sim 20 \%$ & $20 \sim 30 \%$ & $25 \sim 35 \%$ & \\
\hline Zhou Fengqi and Zhou Dadi $^{27}$ & $30 \%$ & & $50 \%$ & $33 \%$ \\
\hline
\end{tabular}

${ }^{20}$ China Statistics Yearbook, No.23, China Statistics Press, 2004.

21 Ibid.

${ }^{22}$ Statistics from National Development and Reform Commission cited in "Hydroelectric Power Accounts for 40\% of Conventional Energy,” China Daily Online, available at http://www2.chinadaily.com.cn/english/doc/200410/27/content_386292.htm, October 27, 2004 (accessed on August 3, 2005).

23 “Nuclear Industry to Seek Foreign Investment,” Xinhua Online, available at http://news.xinhuanet.com/english/2005-07/27/content_3271887.htm, accessed on July 27, 2005.

24 BP Statistical Review of World Energy June 2005.

${ }^{25}$ World Energy Outlook 2002, Paris: International Energy Agency, 2003, p.110 and p.257.

${ }^{26}$ Liu Lili, “Zhouguo shiyou fazhan zhanlue yanjiu” (Researching China’s Oil Development Strategy, Shiyou daxue xuebao(Journal of the University of Petroleum), Social Sciences Edition, Vol. 20, No. 1, February 2004, p.4.

${ }^{27}$ Zhou Fengqi and Zhou Dadi, ed., China's Medium-term and Long-term Energy Strategies (Beijing: China Planning Publishing House, 1999), p.339. 


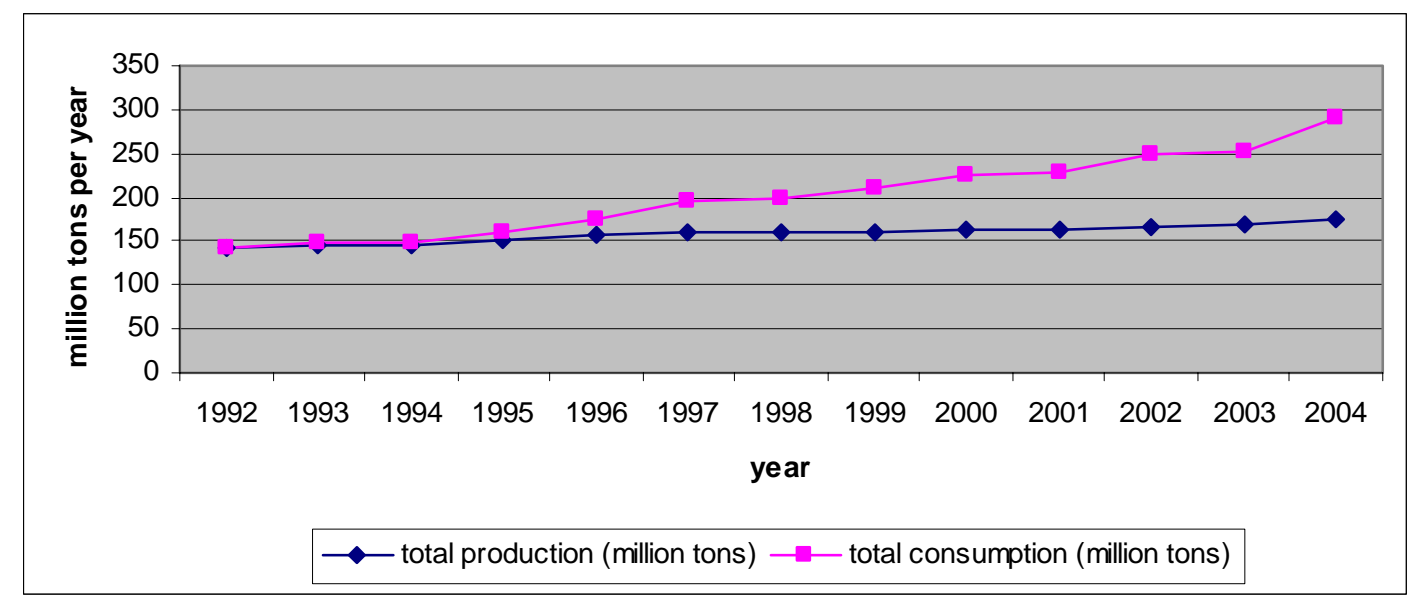

Figure 5. China's oil production and consumption, 1992-2004 ${ }^{28}$

The first factor in China's oil insecurity is foreign dependence. Neither its oil endowment nor its domestic production is sufficient to satisfy the country's guzzling thirst for oil. According to a study conducted by the Shanghai Academy of Social Sciences, China's proved oil reserves only stand at 3300 million tons, accounting for $2.3 \%$ of the world total. However, China's remaining reserves are only 2380 million tons, with a reserves-to-production ratio of 14.8. This means that at the current pace of production and exploration, China's reserves will only last 14 years or so. ${ }^{29}$ On the other hand, domestic oil production has not been able to keep up with the growing demand at home. As Figure 5 demonstrates, since 1991 China's oil consumption has been growing at 5.82\% annually on average, but domestic oil supply is only increasing at $1.67 \%$ annually on average. ${ }^{30}$ Consequently, China had to bid farewell to the era of selfreliance which it enjoyed since 1965 and increasingly depend on imported oil. In 1993 China became a net oil importer and in 1996 a net crude oil importer. Since then China's oil imports have been growing at 16.8\% annually on average, with oil imports in 2004 nearly eight times of those of 1993 (Table 3). As a result, China's dependency on foreign oil is also on a rapid rise, growing from less than $1 \%$ in 1993 to about 48\% in 2004 (Fig. 6).

Furthermore, four long-term trends in China almost make the continued growth of its dependence on foreign oil certain. First, China's economy is predicted to grow above 7\% for the next 15 years. ${ }^{31}$ That growth rate, according to a Chinese think-tank study, requires oil supply to grow at least $4 \%$ annually. ${ }^{32}$ By contrast, from 1990 to 2003 China’s domestic oil production only grew at $1.57 \%$ per annum on average. $^{33}$

${ }^{28}$ China Statistical Yearbook of various years, China Statistics Press.

29 “Lun zhongguo shiyou anquan” (“On Chinese Petroleum Security”), Project team of Report on 2004 China’s International Status, Shanghai Social Sciences Academy, Journal of Petrochemical Technology and Economics (shiyou huagong jishu jinji), Vol. 3, 2004, p.7.

${ }^{30}$ China Statistical Yearbook of various years, China Statistics Press.

31 "Lun zhongguo nengyuan anquan” (“On Chinese Petroleum Security”), Project team of Report on 2004 China’s International Status, Shanghai Social Sciences Academy, Shiyou huagong jishu jinji( Journal of Petrochemical Technology and Economics), Vol. 3, 2004, p.7.

${ }^{32}$ Ibid.

${ }^{33}$ China Statistical Yearbook, No.23, China Statistics Press, 2004. 
Table 3. China's imports of oil and oil products since 1993 (in 10,000 tons)

\begin{tabular}{|c|c|c|c|c|}
\hline Year & Crude oil & Oil products & Total imports & Annual growth of oil imports \\
\hline $1993^{34}$ & 1567.12 & 1729.44 & 3296.56 & N.A. \\
\hline 1994 & 1234.59 & 1288.62 & 2523.21 & $-23.5 \%$ \\
\hline 1995 & 1708.99 & 1440.31 & 3149.3 & $24.8 \%$ \\
\hline 1996 & 2261.69 & 1582.42 & 3844.11 & $22.1 \%$ \\
\hline 1997 & 3547.15 & 2379.65 & 5926.8 & $54.2 \%$ \\
\hline 1998 & 2732.26 & 2173.99 & 4906.25 & $-17.2 \%$ \\
\hline 1999 & 3661.37 & 2081.72 & 5743.09 & $17.1 \%$ \\
\hline 2000 & 7026.53 & 1804.69 & 8831.22 & $53.8 \%$ \\
\hline 2001 & 6025.54 & 2144.89 & 8170.43 & $-7.5 \%$ \\
\hline 2002 & 6940.77 & 2035.2 & 8975.97 & $9.9 \%$ \\
\hline 2003 & 9112.63 & 2823.98 & 11936.61 & $33.0 \%$ \\
\hline $2004^{35}$ & 12272 & & & $34.7 \%$ \\
\hline Average growth & & & & $16.8 \%$ \\
\hline
\end{tabular}

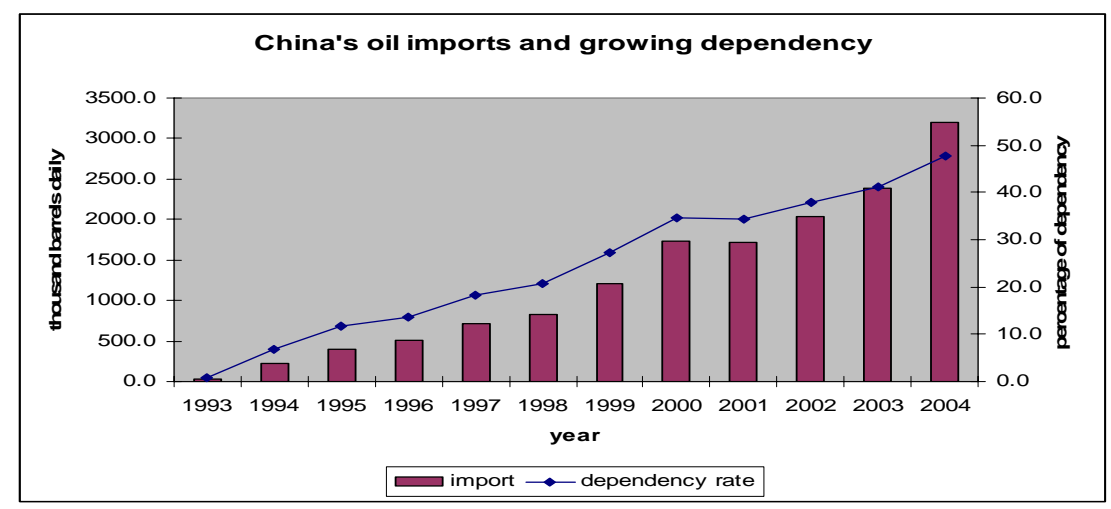

Figure 6. China's dependency on foreign oil ${ }^{36}$

${ }^{34}$ Data on China's oil imports from 1993 to 2002 are drawn on Statistical Yearbooks published by Customs General Administration People's Republic of China of various years cited in Su Biao and Tian Chunrong, "Analysis of China's Petroleum Trade in 1995”(1995 nian zhongguo shiyou jinchukou qingkuang fenxi), Guoji shiyou jingji (International Petroleum Economics), Vol. 4, No. 2, March 1996; Su Biao and Tian Chunrong, “Analysis of China's Petroleum Trade in 1997,” International Petroleum Economics, Vol. 6, No. 2, March 1998; Tian Chunrong, “Analysis of China's Petroleum Trade in 1999," International Petroleum Economics, Vol. 8, No. 2, March 2000; Tian Chunrong, "Analysis of China's Petroleum Trade in 2001," International Petroleum Economics, Vol. 10, No. 3, March 2002; Tian Chunrong, "Analysis of China’s Petroleum Trade in 2003,” International Petroleum Economics, Vol. 12, No. 3, March 2004.

35 “Woguo yuanyou maoyi dui shijie youjia yingxiang youxian” (“China’s Petroleum Trade Has Limited Impacts on World Oil Prices”), Guoji Shangbao, (International Business Daily Online), March 8 2005, available at http://ibdaily.mofcom.gov.cn/\%60Template/NewsTemplate.asp?newsid=93589, accessed September 1, 2005.

${ }^{36}$ China Statistical Yearbook of various years, China Statistics Press. 
Second, China has entered into the stage of heavy industrialization spearheaded by manufacturing, steel, and automobiles in its economic development, with industrial sectors contributing to $64.3 \%$ of its GDP in 2003. ${ }^{37}$ However, China's industrialization demonstrates high energy intensity and low efficiency. As a matter of fact, the industrial sector consumed $68.9 \%$ of China's total energy, $71.6 \%$ of its total oil, and $78 \%$ of its total natural gas. ${ }^{38}$ Nevertheless, the efficiency of energy use in China is only $33.4 \%, 10 \%$ below the world average. In 2001, energy consumption cost China’s terminal energy consumers 1.25 trillion yuan, accounting for 13\% of its total GDP as against only 7\% in the United States which has a GDP roughly seven times larger by exchange rate standard. The amount of energy consumed per unit product in eight energy intensive industries is on average $47 \%$ higher than that in energy efficient economies; however, these eight industries consume $73 \%$ of the total energy consumption by China's industrial sectors. ${ }^{39}$ Hence, achieving the goal set by the $16^{\text {th }}$ Communist Party of China (CPC) Congress of quadrupling its economy by 2020 almost dictates that the country will have to rely on the growth of an industrial sector that consumes an enormous amount of energy, not the least oil.

The third factor in oil insecurity is China's accelerating urbanization which requires more energy. In 2003 the urban population in China reached $40.5 \%$ of its total population, registering a growth of $4.4 \%$ from 2000. This suggests China's urban population grows by $1.4 \%$ on average in the past three years, surpassing the growth rate in the last 22 years (1978-2000) during which urbanization only grew by $0.8 \%$ per year. ${ }^{40}$ At this pace, China's urbanization is predicted to reach between $55 \%$ and $60 \%$ by $2020 .{ }^{41}$ In China, on average, one percentage growth of urbanization means an addition of 13 million people to urban areas. ${ }^{42}$ Therefore, by rough estimate, by 2020 urban dwellers will increase by 212 million to 277 million. According to a Chinese study, China's urban population consumes 3.5 times more energy than its rural population. ${ }^{43}$ Therefore, satisfying this new urban population's demand for more energy, particularly energy in the transport sector, will undoubtedly increase China’s oil demand.

Fourth, while the transport sector only consumed $15.8 \%$ of China's total oil and $2.2 \%$ of its total natural gas in 2002, ${ }^{44}$ it is catching up as a big oil guzzler as the emerging middle class in China starts to travel by air and falls in love with cars. According to the Economist Intelligence Unit, air travelers in China more than tripled from 27.3 million in 1990 to 83.7 million in 2002 and during the same time passenger car registration increased more than 12 times from 198,000 to 2.42 million. ${ }^{45}$ With 5 million car sales last

${ }^{37}$ Ibid.

38 Ibid.

39 “Zhongguo nengyuan fazhan zhanlue yu zhengce yanjiu baogao” (“Report on China’s Energy Development Strategy and Policy”), Project team of Report on China’s Energy Development Strategy and Policy, Jingji cankao yanjiu ( Economic Research and Reference), Vol. 83, 2004, p.7.

40 "Woguo nengyuan gongqiu zhongchangqi fazhan qushi ji kechixu fazhan zhanlue” (The Medium- and Long-term trend of China’s energy supply and demand and China’s Sustainable Development Strategy), Project Team, Energy Research Institute Macroeconomics Research Department National Reform and Development Commission, Jingji yanjiu cankao (Economic Research and Reference), Vol. 92, 2004, p. 4.

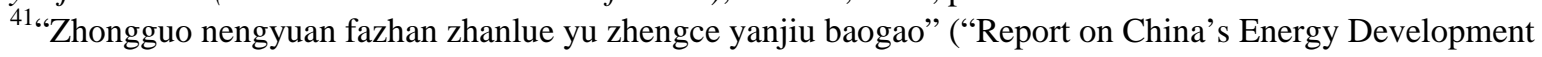
Strategy and Policy”), Project team of Report on China’s Energy Development Strategy and Policy, Jingji cankao yanjiu (Economic Research and Reference), Vol. 83, 2004, p.5.

42 Ibid.

43 Ibid.

${ }^{44}$ China Statistical Yearbook, No.23, China Statistics Press, 2004.

45 "China: Market Indicators and Forecasts,” The Economist Intelligence Unit Data Services, accessed August 1, 2005. 
year, China is already the world's third largest car market, after America (17M) and Japan (5.9M). ${ }^{46}$ Within the next two to three years China is expected to replace Japan as the second largest car market and become the largest auto market between 2010 and 2015. ${ }^{47}$ According to the World Energy Outlook 2004, total Chinese vehicle ownership will reach more than 90 per 1000 persons in 2030 from 9 per 1000 persons in $2005 .{ }^{48}$ Consequently, energy demand for road transport will climb by $6.5 \%$ per year during this decade and energy consumption in transport as a whole will grow by $4.6 \%$ per year from 2004 to $2030 .{ }^{49}$ Moreover, while oil can substitute for coal, hydro-energy, and nuclear power, none can substitute for oil at a reasonable economic cost, not the least in the transport sector at present. Hence, although China's expanding electricity generation capacity will require less oil for power, its increasing vehicle usage will offset that decline.

As a result of the four long-term trends, China's demand for oil is bound to increase. Given the inability of its domestic oil production to meet the mounting demand at home, China's dependence on foreign oil will only continue to grow. Although estimates of its dependency on foreign oil differ, they all point to an alarming trend, foreseeing the dependency rate to be above $40 \%$ by 2010 , above $60 \%$ in 2020 , and above $70 \%$ in 2030 (Table 4). In view of this high dependence on foreign oil, China's oil security is at stake. ${ }^{50}$ Oil insecurity occurs, according to a government-sponsored study, when the sudden disruption of oil supply, oil shortage, or price hikes wreaks damage on an economy, the degree of which is determined by an economy's dependence on foreign oil, the scale of oil price fluctuations and its responsive capabilities such as strategic oil reserves, spare production capacity, alternative energy sources, and an early warning system. $^{51}$

Table 4. Forecasts of China's growing dependency on foreign oil

\begin{tabular}{|c|c|c|c|c|c|}
\hline & 2010 & 2015 & 2020 & 2025 & 2030 \\
\hline International Energy Agency $(2002)^{52}$ & $55 \%$ & & $68 \%$ & & $74 \%$ \\
\hline US Energy Information Administration (2003) ${ }^{53}$ & $44.6 \%$ & $54.5 \%$ & $62.8 \%$ & $68.8 \%$ & \\
\hline $\begin{array}{l}\text { Energy Research Institute, National Development and } \\
\text { Reform Commission }{ }^{54}\end{array}$ & $46 \sim 52 \%$ & & $59 \sim 62 \%$ & & \\
\hline
\end{tabular}

46 “Dream Machines,” Special Report: Cars in China, The Economist, June 4 ${ }^{\text {th }}$, 2005, pp.24-26.

${ }^{47}$ Ibid.

${ }^{48}$ World Energy Outlook 2004, Paris: International Energy Agency, 2004, p.265; Statistics on 2005 vehicle ownership was drawn from Economist Intelligence Database, accessed November 16, 2005.

${ }^{49}$ World Energy Outlook 2004, Paris: International Energy Agency, 2004, p.265.

50 “Zhongguo nengyuan fazhan zhanlue yu zhengce yanjiu baogao" ("Report on China’s Energy Development Strategy and Policy”), Project team of Report on China’s Energy Development Strategy and Policy, Jingji cankao yanjiu (Economic Research and Reference), Vol. 83, 2004, p.12. Also, see Shu Xianlin and Yan Gaocheng, "Shiyou: zhongguo nengyuan anquan de hexin yu guoji zhanlue" (Oil: The Core of China's Energy Security and China's International Strategies), Shiyou huagong jishu jingji (Journal of Petrochemical Technology and Economics), Vol.20, Issue. 3, 2004, p. 13.

51 “Zhongguo nengyuan fazhan zhanlue yu zhengce yanjiu baogao" ("Report on China’s Energy Development Strategy and Policy”), Project team of Report on China's Energy Development Strategy and Policy, Jingji cankao yanjiu (Economic Research and Reference), Vol. 83, 2004, p. 12.

${ }_{52}$ World Energy Outlook 2004, Paris: International Energy Agency, 2004, p.117.

${ }^{53}$ International Energy Outlook 2003, United States Energy Information Administration, May 2003, p.184.

${ }^{54}$ Wang Qingyi, “Zhongguo yu shijie nengyuan shuju” ("Data on China and the World's Energy”), Meitan jingji yanjiu (Journal of Coal Economics Study), Vol.2, 2004, p.76. 


\subsubsection{What are the sources of China's oil insecurity?}

While the failure to meet growing demand for oil at home and the resultant rising dependence on foreign oil trigger its energy insecurity, the availability of foreign oil to China, the reliability of China's oil imports, and the affordability of China's oil imports, together with China's perceptions of them, are threats to the country's oil security. As illustrated by Figure 7, the availability, reliability, and affordability of China's oil/oil imports together its perceptions of these three components, constitute the triangle of its oil insecurity, with arrows in the figure representing the interactions among the three dimensions.

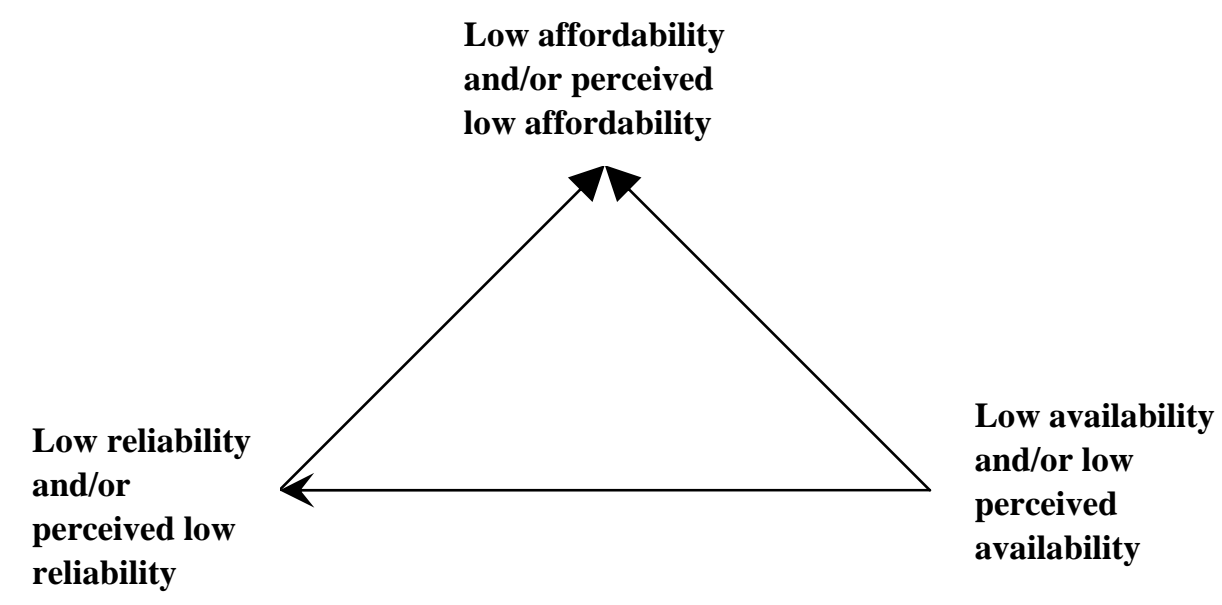

Figure 7. The triangle of China’s oil insecurity

\section{Availability}

First, the limited availability of oil at home and the uneven distribution of oil abroad compel China to depend on only a handful of foreign suppliers. As China is expected to import 10 million barrels of oil per day by 2030, ${ }^{55}$ nearly five times more than today's imports, the immediate question is whether there is enough oil out there to bridge China's supply gap. According to BP, the world's proved oil reserves at the end of 2004 stand at 1188.6 billion barrels, 1.6 times higher than those at the end of 1984 and at the current pace of production they can last about 41 years. ${ }^{56}$ This seems to offer some comfort, yet the availability of oil is greatly dispersed. While the Middle East sits on $61.7 \%$ of world proved oil reserves, China is located in a region that only has 3.5\% of world's proved oil reserves but hosts the world's No. 2, No. 3, and No. 6 oil consumers, namely China, Japan, and India. As a result, China's oil imports also reflect the dispersed distribution of oil resources, namely drawing oil imports principally from the reserves-rich regions in the world. Ever since 1993 when the Middle East replaced the Asia Pacific region to become China's primary oil supplier, this trend has endured. While its oil imports from the Asia Pacific region continue to shrink, West Africa has become the second largest oil supply region for the country. In

\footnotetext{
55 World Energy Outlook 2004, Paris: International Energy Agency, 2004, p.266.

${ }^{56}$ BP Statistical Review of World Energy June 2005.
} 
the meantime, imports start to come from Russia and South America. In 2003, the Middle East provided 50.9\% of China's total oil imports, West Africa 24.3\%, Asia Pacific 15.2\%, and Europe and Western Hemisphere 9.6\% (Fig. 8). However, the imbalance lies in that the two regions alone, the Middle East and West Africa supply $75 \%$ of China's oil imports.

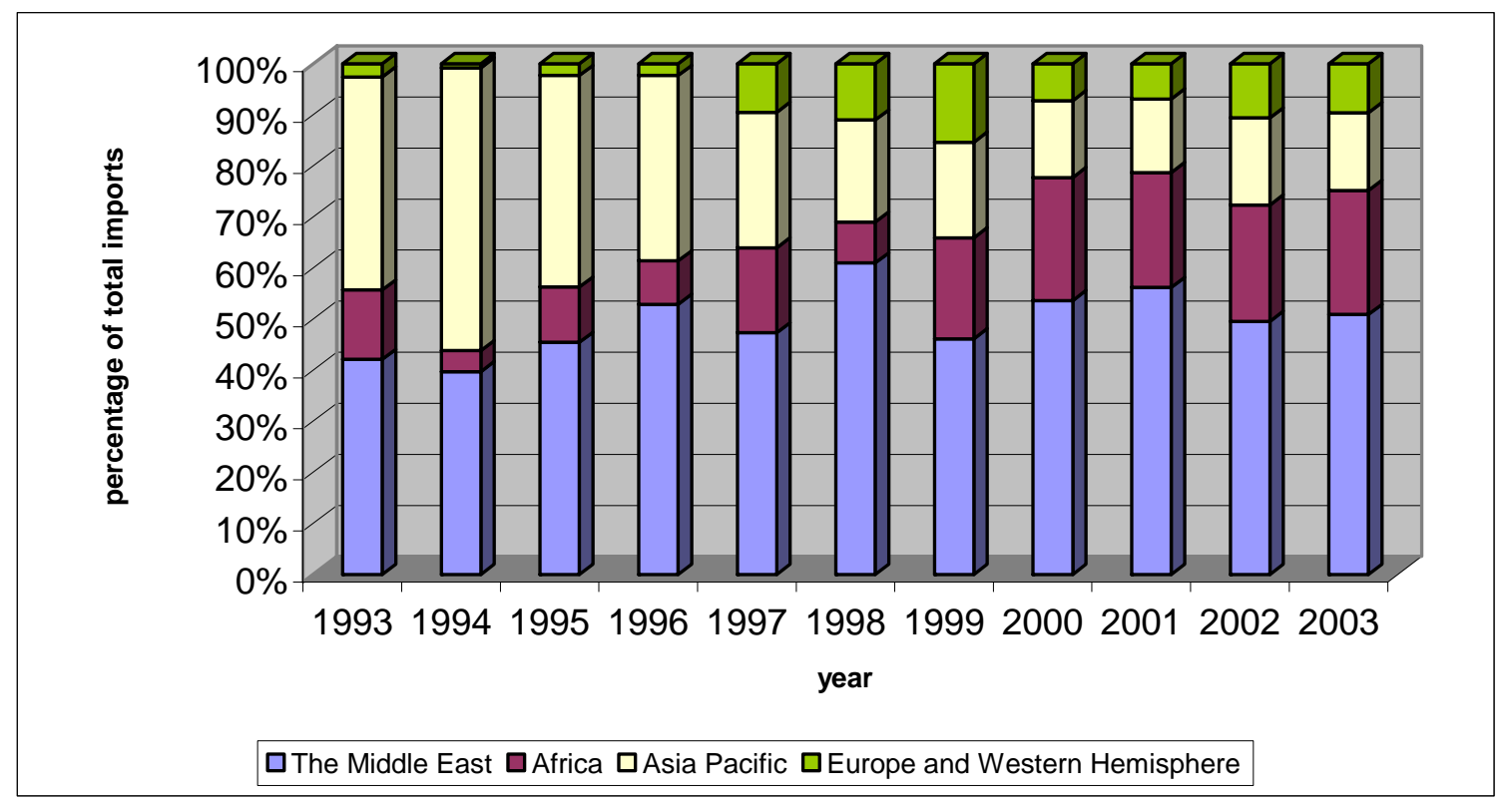

Figure 8. China’s Oil Imports Regions, 1993-2003 ${ }^{57}$

Similarly, a further breakdown of China's top ten oil suppliers also reveals the weakness of China's lopsided import structure. In 2003 China imported more than $80 \%$ of its oil from its top ten suppliers and four of them are Middle Eastern countries, with Saudi Arabia supplying 16.7\%, Iran 13.6\%, Oman 10.2\% and Yemen 7.7\% (Fig. 9). Hence, although there is enough oil abroad to satisfy its oil demand, China's imports are heavily focused on only a few countries which happen to sit in an area prone to instability and volatility. This import structure carries two implications for China's energy security. To start with, this low diversification appears to limit the availability of foreign oil to China. More importantly, this unbalanced import structure highlights China's vulnerability to supply shocks particularly in this small group of exporters, which is tied to the reliability issue of China's oil.

\footnotetext{
${ }^{57}$ Sources: Data are drawn from Statistical Yearbooks published by Customs General Administration People’s Republic of China of various years cited in Tian Chunrong, "1998 nian zhongguo shiyou jingchukou maoyi zhuangkuang fenxi" ("Review of China's oil Imports and Exports in 1998), Guoji shiyou jingji (International Petroleum Economics), Vol.7, No. 2, March 1999, p.14; Tian Chunrong, "2003 nian zhongguo shiyou jingchukou maoyi zhuangkuang fenxi" ("Review of China's oil Imports and Exports in 2003), Guoji shiyou jingji (International Petroleum Economics), Vol.12, No. 3, March 2004, p.11.
} 


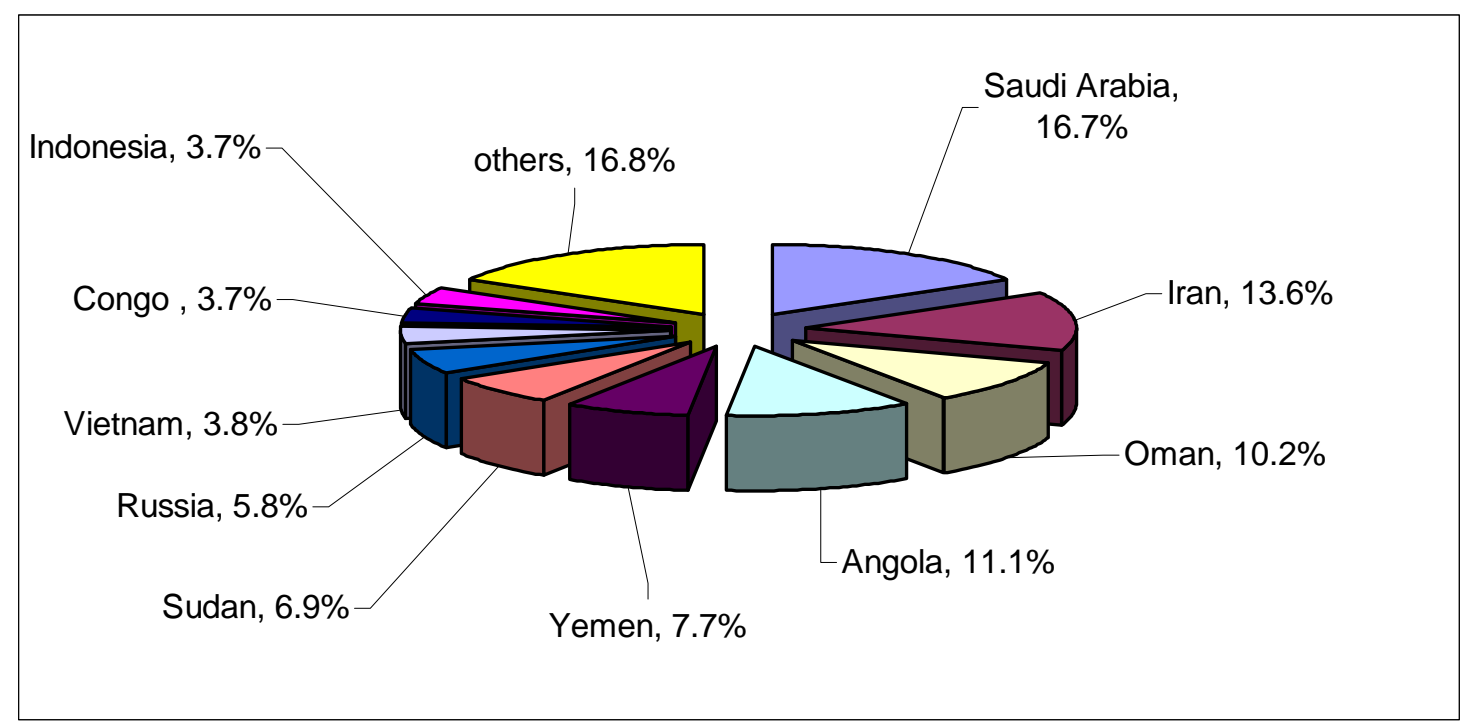

Figure 9. China's oil imports from its top 10 suppliers, $2003^{58}$

\section{Reliability}

Two issues are related to the reliability of China's oil imports. To begin with, the reliability of oil imports from their supply source becomes an issue when the imports are at risk of being denied or disrupted because of a hostile bilateral relationship or instability in the supplier countries caused by war, ethnic conflict, social unrest, terrorism attack against oil facilities, etc. While China maintains good relationships with almost all the oil exporters, its oil suppliers are heavily concentrated in the Middle East and West Africa. Yet both regions are subject to various conflicts and wars, which raise questions about the stability of oil supply. Historically, ethnic conflicts and border disputes have been the primary root causes of instability in the region. Just to name a few, the Iran-Iraq War from 1980 to 1988 and the Iraqi invasion of Kuwait in August 1990 were related in one way or another to border disputes. So are the IsraeliPalestinian conflicts. Today there still exists a potential conflict which is centered on the border dispute between the UAE and Iran over ownership of three islands. Other than conflicts within the region, foreign invasions also threaten oil supply there. For example, the 1991 Persian Gulf War and the recent war in Iraq threatened oil exports from the region. The same holds true for West Africa's oil exporting regions. China's top three oil suppliers in West Africa are all plagued by internal conflicts; with Sudan mired in a civil war, Angola shadowed by ill-implemented disarmament and demobilization between the government and the opposition, and Congo just embarking on a long road to relative stability after years of recurrent civil war. With half of oil imports from the Middle East and about a quarter from West Africa, the reliability of China's oil supplies from these sources is under serious question.

If the concentration of imported supplies from regions prone to instability and fraught with conflicts poses a threat to China's oil security, the weakness of its oil supply is compounded by concerns over the reliability of its oil transport. At the core of the issue are who ships China's oil imports and what route its

\footnotetext{
${ }^{58}$ Data are drawn from Statistical Yearbooks published by Customs General Administration People's Republic of China of various years cited in Tian Chunrong, "2003 nian zhongguo shiyou jingchukou maoyi zhuangkuang fenxi" ("Review of China's oil Imports and Exports in 2003), Guoji shiyou jingji (International Petroleum Economics), Vol.12, No. 3, March 2004, p.11.
} 
oil imports pass through. As Table 5 indicates, in 2002 China imported 69.41 million tons of crude oil, but only 7\% of them, primarily imports from Russia and Kazakhstan, were shipped by railway. The overwhelming majority of China's oil imports, 93\% came via the ocean. However, among the 93\% that was shipped by sea, Chinese crude oil tankers only shipped $10 \%$ of the total, with $90 \%$ carried by foreign fleets. This means that foreign tankers shipped 83.7\% of China's total oil imports in 2002, only leaving $9.3 \%$ of the total oil shipments by sea under Chinese control. As a result, this limited control over oil shipment undoubtedly subjects China's oil imports to various risks of disruption, particularly in times of contingency and mounts another threat to its oil insecurity.

Table 5. Summary of how China's oil imports were shipped in $2002^{59}$

\begin{tabular}{crc} 
& $\begin{array}{l}\text { Volume of imports } \\
(\mathbf{1 0 , 0 0 0} \text { tons) }\end{array}$ & $\begin{array}{c}\text { Percentage of } \\
\text { total imports }\end{array}$ \\
\hline 2002 crude oil imports by tanker & 6450 & $93 \%$ \\
\hline imports by domestic tanker & $680-700$ & $10 \%$ \\
imports by foreign tanker & $5750-5770$ & $90 \%$ \\
\hline 2002 crude oil imports by rail & 491 & $7 \%$ \\
\hline Total crude oil imports in 2002 & 6941 & $100 \%$ \\
\hline
\end{tabular}

A further breakdown of China's oil shipments from its primary importing regions also demonstrates the same weakness in its oil supply chain (Table 6). In 2002, 96.22\% of China's total oil imports from the Middle East were carried by foreign tankers, with only 3.78\% carried by domestic tankers. More strikingly, all of China's oil imports from West Africa in 2002 were shipped by foreign fleet. The only exception comes to the China's imports from Southeast Asia, where domestic tankers carried slightly more than half of its total oil imports. Nonetheless, China imported most from the Middle East and West Africa, where it has least control over the shipments.

Moreover, an investigation of the routes through which its oil imports are shipped also shows signs of insecurity in China's oil supply from overseas. Only 7\% of its total oil imports are shipped by railway from Russia or Kazakhstan to China, the rest of China's oil imports have to pass through different Sea Lines of Communications (SLOCs). However, as Table 7 illustrates, among all imports shipped by sea, all of them except those from Venezuela have to go through the Malacca Strait (Fig. 10). Imports from

\footnotetext{
${ }^{59}$ Chart compiled by the author based on data cited in Qin Xiao, “Zhongguo nengyuan anquan zhanlue zhong de nengyuan yunshu wenti” (“On Energy Supply Security in China’s Energy Security Strategy”), Zhongguo Nengyuan, (China Energy), Vol.26, No.7, July 2004, p.5.
} 
Venezuela are shipped across the Pacific Ocean, but they only accounted for $0.5 \%$ of China's total oil imports. ${ }^{60}$ The overwhelming majority, roughly between $80 \%$ and $85 \%$ of China's oil imports pass

through the strait. ${ }^{61}$ Besides China's oil imports, the Malacca Strait also handles oil imports for other East Asian economies, with fuel imports through the strait composing 32\% and $27 \%$ of world's total trade in oil and natural gas. ${ }^{62}$ Specifically, the Malacca Strait handles 11 million barrels of oil and 40 billion cubic meters of natural gas on a daily basis. ${ }^{63}$ Moreover, the volume of traffic will only grow. In fact, it is expected to double for both crude and LNG tankers by $2030 .{ }^{64}$ However, the narrowest point of this shipping lane, the Phillips Channel in the Singapore Strait, is only 1.5 miles wide at its narrowest point, thus creating a natural bottleneck, with the potential for a collision, grounding, or oil spill. Any of these disasters run the risk of forcing closure of the strait, thereby interrupting or bringing to standstill China's oil imports.

Table 6. Summary of how China's oil imports from different sources were shipped in $2002^{65}$

\begin{tabular}{|c|c|c|}
\hline & $\begin{array}{l}\text { Volume of imports } \\
\text { (million tons) }\end{array}$ & $\begin{array}{l}\text { Percentage of } \\
\text { total imports }\end{array}$ \\
\hline 2002 import from the Middle East & 3439 & $49.55 \%$ \\
\hline by domestic tanker & 130 & $3.78 \%$ \\
\hline by foreign tanker & 3309 & $96.22 \%$ \\
\hline 2002 import from West Africa & 1580 & $22.76 \%$ \\
\hline by domestic tanker & 0 & $0.00 \%$ \\
\hline by foreign tanker & 100 & $100.00 \%$ \\
\hline 2002 import from Southeast Asia & 1049 & $15.11 \%$ \\
\hline by domestic tanker & 550 & $52.43 \%$ \\
\hline by foreign tanker & 499 & $47.57 \%$ \\
\hline
\end{tabular}

\footnotetext{
${ }^{60}$ Tian Chunrong, "2003 nian zhongguo shiyou jingchukou maoyi zhuangkuang fenxi" ("Review of China's oil Imports and Exports in 2003), Guoji shiyou jingji (International Petroleum Economics), Vol.12, No. 3, March 2004, p.11.

61 “Hu Jintao Urges Breakthrough in 'Malacca Dilemma',” Hong Kong Wen Wei Po (Internet Version-WWW), January 14 2004, The World News Connection, FBIS-CHI-2004-0114; also see Liu Lili, "Zhouguo shiyou fazhan zhanlue yanjiu” (Researching China's Oil Development Strategy, Shiyou daxue xuebao(Journal of the University of Petroleum), Social Sciences Edition, Vol. 20, No. 1, February 2004, p.3.

${ }^{62}$ World Energy Outlook 2004, Paris: International Energy Agency, 2004, p.119.

${ }^{63}$ Ibid.

${ }^{64}$ Ibid.

${ }^{65}$ Table compiled by the author based on data cited in Qin Xiao, "Zhongguo nengyuan anquan zhanlue zhong de nengyuan yunshu wenti” (“On Energy Supply Security in China’s Energy Security Strategy”), Zhongguo Nengyuan, (China Energy), Vol.26, No.7, July 2004, p.5.
} 


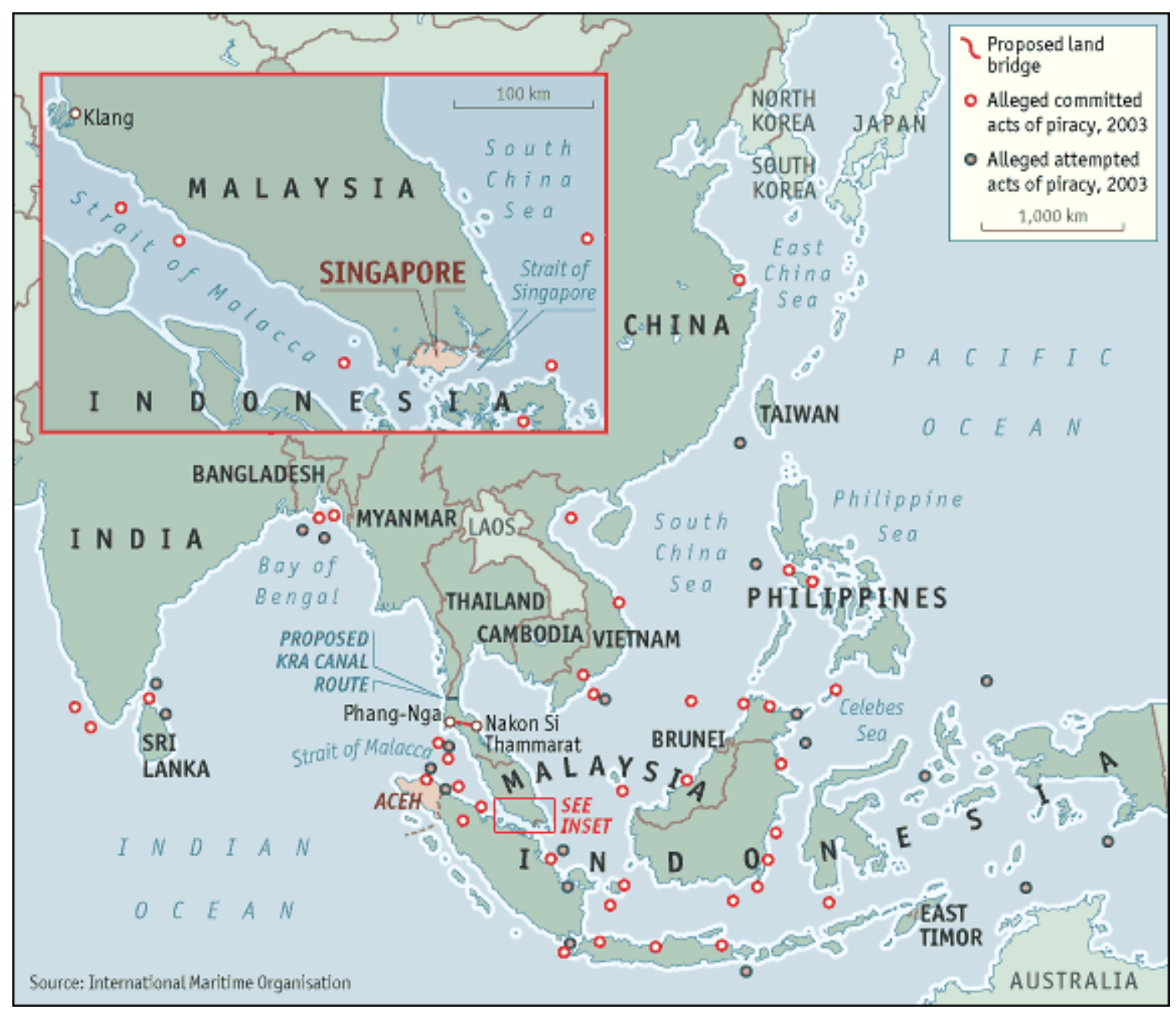

Figure 10. Map of shipping lanes (Source: Economist.com)

Table 7. China's oil transport routes

\begin{tabular}{|l|l|}
\hline \multicolumn{2}{|c|}{ Railway } \\
\hline Russia & Zabaikalsk - Manzhouli \\
\hline Kazakhstan & Kazakhstan - Alashankou \\
\hline \multicolumn{2}{|l|}{ Sea } \\
\hline The Middle East & Persian Gulf - Strait of Hormuz - Malacca Strait - Taiwan Strait - China \\
\hline West Africa & $\begin{array}{l}\text { North Africa - Mediterranean - Strait of Gibraltar - Cape of Good Hope - } \\
\text { Malacca Strait - Taiwan Strait - China }\end{array}$ \\
\hline Southeast Asia & Malacca Strait - Taiwan Strait - China \\
\hline Venezuela & Panama Canal - Pacific Ocean \\
\hline
\end{tabular}


Two more factors contributing to the lack of reliability of China's oil imports through the Malacca Strait are piracy attacks and potential terrorism attacks. Piracy attacks in the strait have risen rather quickly. According to statistics from the International Maritime Bureau, the year 1999 only witnessed two piracy attacks in the area (Fig. 11). But the number of piracy attacks skyrocketed to 75 at the peak in 2000, petered off in the following two years, but bounced back in last two years. These attacks make the strait one of the most dangerous waters in the world. In addition to piracy attacks in the Malacca Strait, a terrorism attack has become an increasing concern. With more than 63,500 ships passing through and traffic growing at more than 5 per cent a year ${ }^{66}$, the International Maritime Bureau's Piracy Reporting Center warned that freighters carrying payloads of fuel through the strait could be hijacked and used in terror operations similar to the 11 September attacks on America. ${ }^{67}$ Piracy attacks or potential terrorism attacks can endanger China's oil security because they can not only literally force the closure of the Malacca Strait and cut off China's oil imports through the shipping lane, but also dramatically mark up the shipping costs of China's oil imports, which are linked to the third source of China's oil insecuritythe affordability of its oil imports.

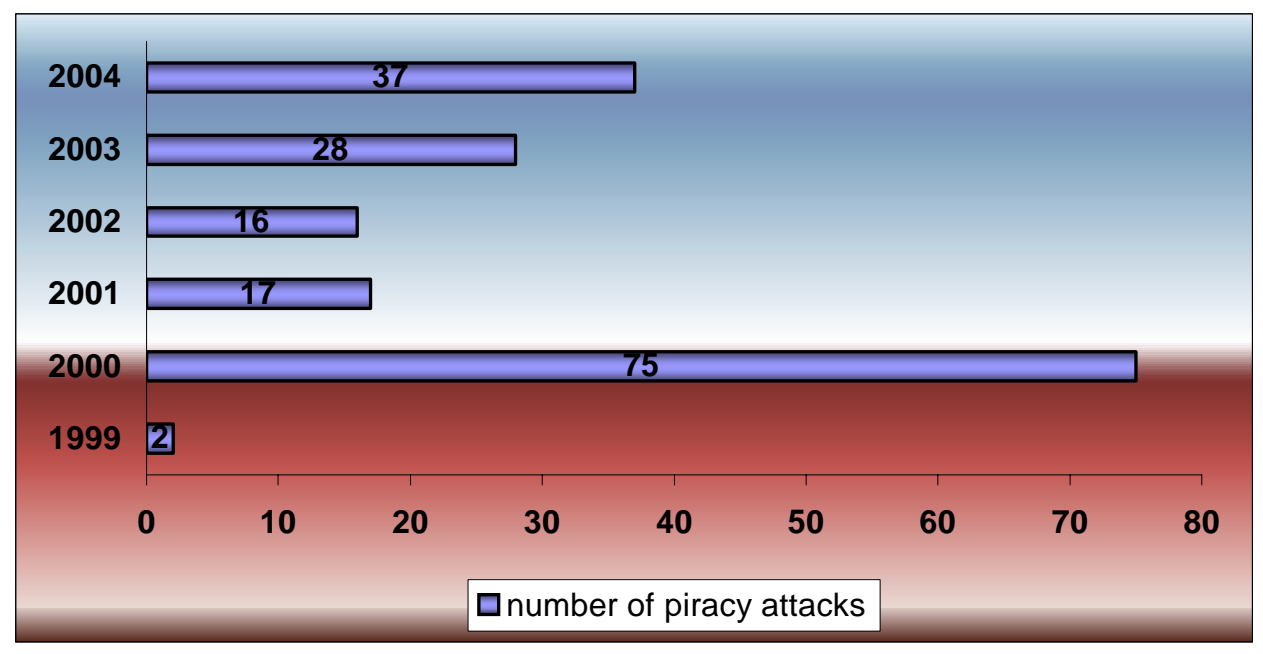

Figure 11. Number of piracy attacks in Strait of Malacca, 1999-2004 ${ }^{68}$

\footnotetext{
${ }^{66}$ Tim Johnson, “Shipping Industry’s Response is All at Sea Malacca Strait,” Financial Times, June 25 2005, p. 4.

${ }^{67}$ Based on the International Maritime Bureau's report cited in "Piracy Terror Attack Warning," BBC News, Internet Version, available at http://news.bbc.co.uk/2/hi/asia-pacific/1799654.stm, February 42002 (accessed August 8, 2005).

${ }^{68}$ Statistics were drawn from the Worldwide Piracy Report by the International Chamber of CommerceInternational Maritime Bureau (IMB) cited in various news reports. Data on 1999 and 2000 are from "Piracy at 10Year High,” BBC News, Internet version, available at http://news.bbc.co.uk/1/hi/world/asia-pacific/1146289.stm, January 312001 (accessed August 8, 2005); statistics on 2001 is from Raja Simhan T.E., "Fall in Piracy Attacks in Malacca Strait,” The Hindu Business Line, Internet version available at http://www.blonnet.com/2002/02/16/stories/2002021600680800.htm, February 152002 (accessed August 8 2005); Data on 2002 and 2003 are from "Number of Piracy Attacks Up 20\% Around the World," Industry News, CV International Inc., available at http://www.cvinternational.com/news013004Sing.htm, January 302003 (accessed August 8, 2005); Statistics on 2004 is from Tim Johnson, "Shipping Industry's Response is All at Sea Malacca Strait," Financial Times, June 25 2005, p. 4.; also, see Bronson Percival, "Indonesia and the United States: Shared Interests in Maritime Security,” p.7, published by the United States-Indonesian Society, June 2005, available at http://www.usindo.org/pdf/Maritime\%20Security.pdf, accessed September 22, 2005.
} 


\section{Affordability}

The final contributor to China's energy insecurity is the affordability of its oil imports, namely whether oil is priced in a range that is commensurate with China's purchasing power and does not impose huge cost on its economic development. It becomes a security issue for the country because growing quantities of oil imports magnify the effects of price fluctuations on its economic growth. Since it became a net oil importer, the money China spends on oil imports has grown more than eight times from $\$ 2.3$ billion in 1993 to $\$ 19.8$ billion 2003, with an average growth of more than 38\% annually (Fig. 12). Moreover, expanded oil imports accounted for only 2.23\% of China's total expanded imports in 1993, but by 2003 they made up 4.8\% of the country's budget for aggregate imports, more than doubling the share in 1993. In the past decade, China's expanded oil imports have registered a 17.6\% growth on an annual basis. As a result, China's economy increasingly feels the negative impact of high oil prices.

According to a Chinese study, for every increase of 10 dollars per barrel of oil, China's economic growth will slow down by one percentage point. ${ }^{69}$ However, according to an economist at Morgan Stanley, China needs to grow at least $7 \%$ per annum to compensate for the job reductions that arise from ongoing reforms of state-owned enterprises-an elimination of 8-10 million jobs each year. ${ }^{70}$ Moreover, high oil prices will lead to inflation, with the Consumer Price Index (CPI) increasing by $0.4 \%$ for every $\$ 10$ hike per barrel of oil. ${ }^{71}$ As the Chinese government learned from 1989, high inflation can induce students to take to the street, thus threatening political stability. Hence, the affordability of oil becomes a security challenge because it could undermine the country's sustained rapid growth, which is vital for stability of the Chinese system—stability in economic, social, and even political terms.

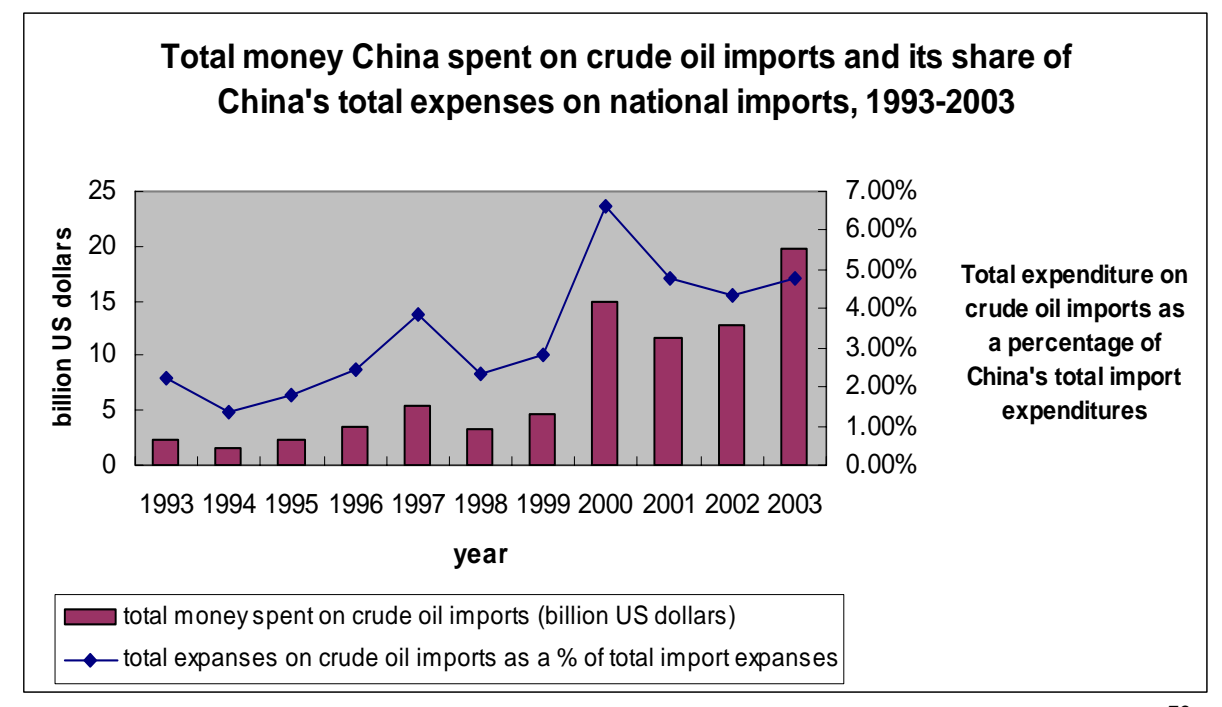

Figure 12. Chinese expenditures on oil imports and share of total imports ${ }^{72}$

\footnotetext{
${ }^{69}$ Liao Hong and Chen Yun, (Tebie cehua: duiyi zhanzheng, zhongguo jingji sunshi you duoda?) ("Special Report: What is the magnitude of Chinese Economic Losses Resulting from the Iraq War?”), People Daily Online, available at http://past.people.com.cn/GB/jinji/31/179/20030225/930064.html, February 252002 (accessed August 4, 2005).

${ }^{70}$ Stephen Roach, “Global: China Goes for Growth,” Global Economic Forum, Morgan Stanley, available at http://www.morganstanley.com/GEFdata/digests/20050322-tue.html, March 222005 (accessed August 9, 2005).

71 “Zhuyou shanshan laichi, zhongguo zhanlue shiyou chubei zhongjiang qihang,” (China’s Strategic Petroleum Reserves Will Be Launched after Some Delay), China Oil News Online, available at http://www.oilnews.com.cn/gb/mis/2005-07-19/content_624339.htm, July 19 2005, accessed August 20, 2005.

72 Data are drawn from Statistical Yearbooks published by Customs General Administration People's Republic of China of various years cited in "1998 nian zhongguo shiyou jingchukou maoyi zhuangkuang fenxi" ("Review of
} 
The affordability issue in China's energy security is linked to both the availability issue and the reliability issue (Figure 7). First, the availability and the magnitude of availability of oil largely determine oil supply on the market, thereby setting the affordability of oil. Second, both the reliability of oil supply from its sources and the reliability of oil in transit affect the affordability of oil. Any factors that add uncertainty to or disrupt the reliable oil supply, such as hurricanes, strikes, civil conflicts, war, or terrorist attack, will push up oil prices and negatively impact the affordability of China's oil. Similarly, any disruption of China's oil shipping lanes, particularly the Malacca Strait will drive up the shipping cost of its oil imports. A small scale attack on China's oil shipments through the strait, such as a piracy attack, could add shipping costs by compelling the Chinese oil companies to pay pirates' ransoms. According to the Financial Times, the average ransom paid for per kidnap in 2004 is estimated at 50,000 dollars. ${ }^{73}$

On the other hand, a large scale attack forcing closure of the strait will wreak much more havoc. To skip the strait will force ships to travel an extra 994 miles from the Persian Gulf. As a result, longer sailing times would strain current tight shipping capacity, causing freight rates worldwide to increase, and raise the price of new shipments at a time when demand is exceeding supply. Moreover, any war or terrorism attacks in the region could also force ship and cargo insurance rates to skyrocket to prohibitive levels. In fact, in its report presented to the Joint War Committee (JWC) of Lloyd's Market Association, Aegis Defense Services, a UK-based security consultancy, recently classified the Malacca Strait as a war and terrorism risk. ${ }^{74}$ As a result of the new risk label, according to Marsh, a leading global insurance broker, ship owners will face additional insurance premiums of about 50 million dollars annually. ${ }^{75}$ Increases in the cost of oil shipments will lead to higher oil prices, thereby inflicting higher costs on China's economic development.

\subsection{Institutional insecurity}

Other than cyclical and structural insecurity, institutional insecurity represents another important facet of China's energy insecurity. To a large degree, it both causes and aggravates the previous dimensions of China's energy insecurity. Take the cyclical power shortage for example: a huge error was made by the State Development and Planning Commission (SDPC), the predecessor of NDRC, when it was drafting China's electricity policy shortly after the Asian Financial Crisis, during which China's growth slowed down. Based on the then-current trend, the SDPC issued a policy of "no coal-fired power plants in the next three years.” As a result, the growth of investment in the power sector took a nose dive, with growth of installed power capacity plummeting from 20 million kilowatts in 1997 to 10.21 million kilowatts in 1999 and further plunging to 6 million kilowatts in $2000 .^{76}$ By then, however, rapid growth-driven

China's oil Imports and Exports in 1998), Guoji shiyou jingji (International Petroleum Economics), Vol.7, No. 2, March 1999, p.17; Tian Chunrong, "2003 nian zhongguo shiyou jingchukou maoyi zhuangkuang fenxi" ("Review of China's oil Imports and Exports in 2003), Guoji shiyou jingji (International Petroleum Economics), Vol.12, No. 3, March 2004, p.10.

73 Stephen Fidler and Arlen Harris, “Pirates Hold Malacca Strait Hostage to A Fortune,” Financial Times, June 23 2005, Section 1, p. 20.

${ }^{74}$ John Burton, “Anger at Malacca Strait Risk Label,” Financial Times, August 5 2005, p. 7.

75 Ibid.

76 “2004 nian zhongguo da quedian: sanfen tianzan, qifen renhuo” (Electricity shortage in 2004: 30\% natural disasters and 70\% human errors), Xinhua News, Internet version, available at

http://news.xinhuanet.com/stock/2004-12/22/content_2366867.htm, December 22 2004, accessed August 19, 2005. 
demand for electricity in China had far surpassed the investment (Table 8). As a result, power shortages emerged in 2002 and worsened afterwards.

Table 8. Summary of growth of China's electricity consumption and investment, 2000-2003 ${ }^{77}$ :

\begin{tabular}{|c|c|c|}
\hline & $\begin{array}{c}\text { Growth of electricity } \\
\text { consumption }\end{array}$ & $\begin{array}{c}\text { Growth of installed } \\
\text { capacity }\end{array}$ \\
\hline 2000 & $11.36 \%$ & $6.88 \%$ \\
\hline 2001 & $9.03 \%$ & $6 \%$ \\
\hline 2002 & $11.60 \%$ & $5.34 \%$ \\
\hline 2003 & $15.40 \%$ & $9.77 \%$ \\
\hline
\end{tabular}

On the surface, the SDPC's ill-formulated electricity policy looks like a one-time blunder. However, it actually reflects the weakness of China's energy policy making, which is diffuse, overlapping, ad-hoc, and ill-coordinated. First, it is not clear in China who makes energy policy. Ever since 1993 when the Ministry of Energy was abolished, there exists no unitary central energy policy making body in China. From 1993 to 1998 the regulatory power over energy was divided along sectors — coal, oil, and power. However, the 1998 restructuring further diffused the energy policy making system, with the Ministry of Coal and the Ministry of Power disbanded and their power deregulated to different central government ministries, local government agencies, and state owned enterprises (SOEs). As a result, there appeared a three-layered energy decision-making system in China. At the central level, the regulatory power over energy was diffused among the National Development and Reform Commission (which is the successor of SDPC), the Ministry of Land and Resources, the Ministry of Water Resources, the Ministry of Science and Technology, the State Commission of Science, Technology and Industry for National Defense (COSTIND), the State Environmental Protection Administration (SEPA), the Chinese Academy of Engineering, and the State Electricity Regulatory Commission (SERC). Although the NDRC is the designated body in charge of overall energy policy in China, it has to coordinate with the Ministry of Land and Resources regarding mining or drilling, with the Ministry of Water Resources regarding dam projects, with the SEPA regarding pollution control, with SERC over power investment and power plant construction, with the Ministry of Finance regarding project financing, etc.

In addition to central governmental regulation, dominant companies in China's energy market also play a role in making energy policies, partly because they are monopolies of the market and partly because they manage their subsidiaries vertically across the nation. Therefore, they are also de facto market regulators, particularly when it comes to joint ventures with other entities, wholesale and retail. In the oil sector, for example, the four oil companies_-China National Petroleum Corporation (CNPC), China Petrochemical Corporation (Sinopec), China National Offshore Oil Corporation (CNOOC) and Sinochem Corporation (Sinochem), to a large extent are both players and regulators. The executives of these four national oil companies (NOCs) are all at the ministerial level in terms of their official status. Similarly, in the power

\footnotetext{
${ }^{77}$ Based on official statistics cited in "2004 nian zhongguo da quedian: sanfen tianzan, qifen renhuo” (Electricity shortage in 2004: 30\% natural disasters and 70\% human errors), Xinhua News, Internet version, available at http://news.xinhuanet.com/stock/2004-12/22/content_2366867.htm, December 22 2004, accessed August 19, 2005.
} 
sector, other than the central government ministries, "seven sisters" composed of five power generating companies and two state grid companies-Huaneng Group, Huadian Power, Guodian Power, Datang Power Group, China Power Investment Company plus State Power Grid Corporation and the Southern Power Grid Corporation—also double as market participants and market regulators. At the local level, local government agencies, branch offices of those energy-related central government agencies and local offices of the state owned energy companies are all involved (Table 9).

Table 9. Summary of China’s multi-layered energy decision making system

\begin{tabular}{|c|c|c|}
\hline Central Level & Mid-level & Local Level \\
\hline $\begin{array}{l}\text { NDRC } \\
\text { Ministry of Land and Resources } \\
\text { Ministry of Water Resources } \\
\text { Ministry of Science and Technology } \\
\text { COSTIND } \\
\text { SEPA } \\
\text { Chinese Academy of Engineering } \\
\text { SERC }\end{array}$ & $\begin{array}{l}\text { Major state-owned energy companies, e.g.: } \\
\text { Oil and gas sector: “four sisters” } \\
\text { CNPC, Sinopec, CNOOC, Sinochem } \\
\text { Corporation } \\
\text { Power Sector: “seven sisters” } \\
\text { Huaneng Group } \\
\text { Huadian Power } \\
\text { Guodian Power } \\
\text { Datang Power Group } \\
\text { China Power Investment Company } \\
\text { State Power Grid Corp. } \\
\text { Southern Power Grid Corp. } \\
\text { Coal sector: } \\
\text { State-owned coal mines }\end{array}$ & $\begin{array}{l}\text { Local branches of } \\
\text { central government } \\
\text { agencies } \\
\text { Local government } \\
\text { agencies }\end{array}$ \\
\hline
\end{tabular}

As a consequence of the multi-layers, there are "too many cooks" in China's energy system. All power, be it decision making power, regulatory power, or enforcement power, has to be either shared or divided and, more importantly, it is not clearly defined among the different entities involved in the decision making process. Consequently, at the central level, any decision has to be reached by consensus through prolonged bargaining, thereby making China's energy decision making process very additive and messy. ${ }^{78}$ Often times, decisions come in the form of a compromise, satisfying no one in the bargaining process. Moreover, at the national level, the absence of a central energy policy making body essentially means that the central government forsakes its authority over energy policy and leaves it up for grabs among different ministries, local governments, and state-owned energy companies. As a result, the absence of a unitary energy policy leader in China makes any energy policy making process a treadmill, invariably involving fight among different ministries or regulatory bodies. At the local level, with all those "cooks," enforcement of any national energy policy is difficult and coordination is seldom achieved. For example, when the SDPC issued an order against investing in power plants back in 1998, some local governments still brought many power plants on board. But it turned out that they made the right decision when the next round of power shortages kicked in as they have more generating capacity. Ironically, in

\footnotetext{
${ }^{78}$ For a detailed study of China’s energy policy making process, see Kenneth Liberthal and Michel Oksenberg, Policy Making in China, Leaders, Structures, and Processes (Princeton, NJ: Princeton University Press, 1988). For a more recent account of energy policy making in China, see Phillip Andews-Speed, “Chapter Two: Energy Policy and Policy Making in China,” in Energy Policy and Regulation in the People's Republic of China (The Hague/London/New York: Kluwer Law International, 2004 )
} 
this latest round of power shortages local governments again are ignoring the NDRC's orders against overinvestment in power sectors, which will soon result in real overcapacity in the power generating sector.

Second, while the multi-layers in China's energy policy making structure fragment and paralyze its energy policy making process, the designated watchdog of its energy policy, the Energy Bureau under the NDRC, is too poorly prepared to safeguard the country's energy security. In addition to being crippled by the multi-layer system, it lacks political power and is short of staff. The Energy Bureau is only one of the over 20 sub-departments under the NDRC. In terms of power delegation, it is not even equivalent to the three national oil companies in China, whose executives are of ministerial level. Moreover, it is staffed by 30 people and only three of them are responsible for compiling and analyzing energy data. By contrast, the Department of Energy of the United States has about 14,000 people and 600 focus on statistical compilation and analysis of US and international energy markets. Shortage of staff at the Energy Bureau is further aggravated by the fact that the regulatory power over energy investments is supposed to sit with the Energy Bureau as well. However, the tons of energy project proposals and evaluations alone overwhelm the 30 people and consume all their time, making it impossible for them to focus on an overall national energy strategy. Consequently, like many other agencies, the Energy Bureau is caught in the web of dealing with routine requests for administrative work rather than focusing on overall coordination and long term strategies. As a result, energy policy made in China normally is ad-hoc and short-term oriented.

Third, the institutional dimension of China's energy insecurity also originates from China's lack of any energy security safeguard mechanisms. Primarily, the lack of a futures market and strategic petroleum reserves (SPRs) highlight the country's vulnerability to supply and price shocks. For example, until very recently almost all of China's oil imports were priced on the spot market and though the three national oil companies have some commercial reserves the country does not have SPRs. Therefore, any supply shocks or prices shocks immediately translate into economic losses to the Chinese economy.

Fourth, the monopolized energy market structure forms another institutional aspect of China's energy insecurity. To be specific, although the central government created the seven sisters in the power sector, it has the administrative prerogative over power investments. However, it lacks local knowledge about specific demand for power in different places. Due to this disconnect, cyclical power shortages occur in China in an erratic fashion. Similarly, in the oil sector, until very recently only the four national oil companies had the right to import oil from abroad. As a result, there emerges a dilemma that on the one hand there is not enough oil and on the other hand only four companies are allowed to import oil. This mismatch happens in the fuel oil sector as well. On the one hand, private gas stations are allowed to function. On the other hand, they have no direct access to gasoline. They have to rely on the four majors in China's oil market which are reluctant to supply the product when domestic prices are lower than international market prices, thereby contributing to the fuel oil shortages.

To sum up, China's energy insecurity is multi-faceted and springs from three sources-cyclical insecurity, structural insecurity, and institutional insecurity. These three dimensions are intertwined, with institutional insecurity contributing to the cyclical insecurity and exacerbating the structural insecurity. Taken together, however, both the cyclical insecurity and institutional insecurity can be remedied rather quickly if they become a top the priority of the government, whereas due to long-term trends and domestic constraints, structural insecurity, particularly oil insecurity, is here to stay with China for quite a 
while. Hence, a government study concluded "from the long-term and global point of view, the energy issue is an oil issue."79

\subsection{How does China perceive its energy insecurity?}

While cyclical insecurity, structural insecurity, and institutional insecurity constitute the country's actual energy insecurity, its perceptions about insecurity differ and really drive its energy policy. Before embarking upon the discussion of China's strategies in response to energy insecurity, it is worth exploring how the Chinese government perceives its energy security.

Energy has always been deemed strategically important in China. Even back in 1980, Deng Xiaoping acknowledged "energy as the primary issue of the economy." 80 Similarly, the $16^{\text {th }}$ CPC Congress in 1982 stipulated that energy should be the strategic focus of China's economic and social development. ${ }^{81}$ Moreover, together with grain and water resources, oil resources have recently been listed as the major strategic resources in influencing the continued development of the Chinese economy and society. ${ }^{82}$ However, the concerns about energy security are very recent and largely centered on China's oil security. As one government-supported study concludes, from the long-term and global point of view, energy security more accurately is oil security. ${ }^{83}$ The emphasis on oil security was also evidenced at a central economic work conference on November 29, 2003, where CPC Central Committee General Secretary and State President Hu Jintao conceptualized oil and finance as the two national economic security issues. ${ }^{84}$

Chinese perceptions about oil insecurity also fall along the lines of concerns about the three issues previously discussed, the availability, reliability and affordability of its oil imports. First, Chinese have a very ominous view of oil resources available to them abroad. Half of China's oil imports come from the Middle East, and the share of oil imports from Central Asia is growing rapidly. This trend will continue even in the future. According to an official study, by 2020 oil supply from the Middle East will still capture about half of the country's total imports and imports from Central Asia capturing about one-fifth (Table 10). However, the Chinese perceive that these two primary supply regions are under the control of US-led western capital and that it is difficult for China to land new supply deals. ${ }^{85}$ The same pattern holds true elsewhere for Chinese energy companies. According to a strategist from CNPC, western multinational oil corporations such as ExxonMobil, BP-Amoco, and Royal Dutch/Shell, control more

\footnotetext{
79 “Zhongguo nengyuan fazhan zhanlue yu zhengce yanjiu baogao” (“Report on China’s Energy Development Strategy and Policy”), Project team of Report on China’s Energy Development Strategy and Policy, Jingji cankao yanjiu (Economic Research and Reference), Vol. 83, 2004, p.12.

${ }^{80}$ Ibid, p.30.

${ }^{81}$ Ibid.

82 “China Injects Oil into the $21^{\text {st }}$ Century,” Xinhua Domestic Service, April 12 2002, The World News Connection, FBIS-CHI-2002-0419, accessed July 52005.

83 “Zhongguo nengyuan fazhan zhanlue yu zhengce yanjiu baogao" ("Report on China’s Energy Development Strategy and Policy”), Project team of Report on China’s Energy Development Strategy and Policy, Jingji cankao yanjiu (Economic Research and Reference), Vol. 83, 2004, p.12.

84 "Chongqing lizheng zhongmian shiyou guandao ruyu" (Chongqing Fights for the Passage of the China-Burma Oil Pipeline), People’s Daily Online, available at http://finance.people.com.cn/GB/1038/3277783.html, accessed July 19 2005.

${ }^{85}$ Wuqiang, "Nengyuan waijiao: 21 shiji zhongguo de waijiao xin keti," (Energy Diplomacy: the New Task Facing China's Diplomacy in the $21^{\text {st }}$ Century), Guoji zhengzhi yanjiu (Studies of International Politics), Issue 1, 2001, p. 15.
} 
than $80 \%$ of world's high quality oil reserves, more than $30 \%$ of the total value of the world petroleum industry, 50\% market share of world petroleum technological services, $65 \%$ global petroleum trade and investment, and more than $80 \%$ of the cutting-edge petrochemical technology. ${ }^{86}$ Hence, the Chinese envisage themselves in a very disadvantageous position in accessing world’s oil reserves.

Table 10. Forecast of China's oil import diversification ${ }^{87}$

\begin{tabular}{|l|c|c|}
\hline & $\mathbf{2 0 0 3}$ & $\mathbf{2 0 2 0}$ \\
\hline The Middle East & $50.9 \%$ & $45-50 \%$ \\
\hline Africa & $24.3 \%$ & $25 \%$ \\
\hline Asia Pacific & $15.2 \%$ & $5 \%$ \\
\hline Russia and Central Asia & $7.3 \%$ & $20-25 \%$ \\
\hline
\end{tabular}

Adding to the concern about the availability of oil for Chinese purchase is the country's worry about both the reliability of oil imports from its sources of supply and from transport through the SLOCs. The former concern stems from the fact that China imports oil from only about 30 countries, the majority being less than stable countries in the Middle East and Africa. As a result of this concentration, China perceives its oil imports can easily fall victim to violent activities in these two regions. Commonly cited concerns about the vulnerability in the SLOCs is the threat of piracy. However, Chinese reports cite the fear of US hegemony in the region as their primary source of concern over this bottleneck in oil imports. While the Chinese have to live with those home-grown violent events or natural disasters, they are increasingly worried about the "collateral damage" on oil imports reliability from US actions in the region. Their concern is that the instability caused by US military actions or foreign policy in China's primary oil supply regions will negatively affect its imports stability and long-term access to oil resources.

As 93\% of China's oil imports are shipped by sea, 90\% of which are shipped by international tankers and more than $80 \%$ of which are shipped through the Malacca Strait, how to maintain a reliable oil shipment constitutes a serious challenge to the country's oil security. This is exceptionally worrying to China because, as some Chinese scholars point out, at present the country does not have enough naval power to protect the SLOCs through which its energy imports are shipped. Therefore, overdependence on imports from the Middle East and Africa and the limited SLOCs, especially the Malacca Strait, have made the vulnerability of the country's oil imports apparent. ${ }^{88}$ Moreover, the SLOCs are patrolled or jointly patrolled by the US navy or the navies of its allies, whose intentions are dubious to Chinese. In fact, many Chinese think that the United States, threatened by China's rise, sees China as a competitor and will attempt to contain China by using oil supplies as a convenient instrument. ${ }^{89}$ Therefore, when the Chinese

\footnotetext{
${ }^{86}$ Liu Lili, “Zhouguo shiyou fazhan zhanlue yanjiu” (Researching China’s Oil Development Strategy, Shiyou daxue xuebao(Journal of the University of Petroleum), Social Sciences Edition, Vol. 20, No. 1, February 2004 , p.3.

87 "Lun zhongguo nengyuan anquan” (“On Chinese Petroleum Security”), Project team of Report on 2004 China’s International Status, Shanghai Social Sciences Academy, Shiyou huagong jishu jinji( Journal of Petrochemical Technology and Economics), Vol. 3, 2004, p.7.

${ }^{88}$ Liu Xinhua and Qin Yi, “Zhongguo de shiyou jinkou jiqi zhanlue xuanze” (“China’s Oil Imports and its Strategic Choices”), Xiandai guoji guanxi, (Current World Affairs), 2002 Vol. 12, p. 27.

${ }^{89}$ Shu Xianlin and Yan Gaocheng, "Shiyou: zhongguo nengyuan anquan de hexin yu guoji zhanlue," (Oil: the Core of China’s Energy Security and China’s International Strategies), Shiyou huagong jishu jingji (Journal of Petrochemical Technology and Economics), 2004 Vol. 20, Issue 2, p. 3.
} 
think about oil security what haunts them most is their suspicion that the United States might attempt to cut off China's oil supply in the event of war across the Taiwan Strait or conflict between the two countries. Not surprisingly, they interpret some buildup of military bases in the region as very threatening. In fact, according to some Chinese scholars, in recent years the United States has been constructing the "Pacific chain" along the islands of Japan, the Taiwan Strait, and the Philippines to "encircle" China; moreover, the United States also established a military port in the Malacca Strait, perhaps to control China's major oil route. ${ }^{90}$ As a result, worries about the reliability of China's oil imports are evident in the top leadership's thinking. Indeed, at the central economic work conference on November 29, 2003, Hu Jintao reportedly expressed extreme concerns over the "Malacca dilemma" that bears on China's oil security. ${ }^{91}$

Concerns about the availability and reliability are both tied to China's perceptions about the affordability of its oil imports. Overall, the Chinese are very distrustful of the world energy market and do not see oil prices determined by supply and demand. In fact, they view the prices of the world's oil resources as manipulated by major international monopoly capital and international speculation capital. ${ }^{92}$ With SPRs and a futures market yet to be established in China, many Chinese think that China is a victim of all those countries with the power to manipulate the oil markets. Given China's increasing dependence upon foreign oil, high oil prices are perceived as inimical to its economy since they will increase outflow of its foreign exchange reserves and affect its balance of payment (BOP). With an import of 2.4 million barrels of oil per day in $2004^{93}$, a one dollar increase in oil prices per barrel means an annual increase of $\$ 876$ million for oil imports. Undoubtedly, a price spike of a larger magnitude would make a noticeable dent in China's trade surplus, which was only 32 billion dollars in 2004. More importantly, the government is extremely concerned that high oil prices will slow down China's economic growth, which underpins its stability and the survival of the political regime.

Other than the general concerns about oil security, Chinese perceptions about oil security are largely event driven and evolving. Two events stand out, namely the 9/11 attacks on the United States and the war in Iraq, and really shed light on how Chinese perceptions about oil security are shaped up. For this reason, two case studies are in order.

\section{Case 1: How does the US response to 9/11 attacks on America affect China's oil security?}

While China offered various help to the United States shortly after the September 11 attacks, it held an asymmetrical perception of the extent of threat posed by terrorism. What concerned China most was how US reactions to the 9/11 attacks actually affected China's energy security.

As mentioned before, China views its energy security through the prism of the availability, reliability, and affordability of its oil imports. Although neither the 9/11 attacks nor the US reactions have led to any

\footnotetext{
${ }^{90}$ Ibid.

91 “Hu Jintao Urges Breakthrough in 'Malacca Dilemma',” Hong Kong Wen Wei Po (Internet Version-WWW), January 14 2004, The World News Connection, FBIS-CHI-2004-0114; also see Liu Lili,

${ }^{92}$ Li Xinxin, “China’s Energy Security as Viewed from Eight Perspectives,” Liangwang, March 31 2003, pp.39-41. The World News Connection, FBIS-CHI-2003-0410.

${ }^{93}$ See Table 2. Note one ton of oil is equivalent to 7.33 barrels.
} 
reallocation of oil resources around the world in the short term, China is very distrustful of the US longterm intentions in Central Asia. According to a scholar from the Development Research Center of the State Council in Beijing, the US inroads into Central Asia after September 11 allowed it to kill three birds with one stone: to control the strategic area of Central Asia, to contain China, Iran and Russia, and to control oil and natural gas resources in the Caspian Sea region. ${ }^{94}$ As a consequence, in the long term, China believes the US presence in the region will complicate its access to energy resources there.

Moreover, China is very concerned about the impact of US reactions on the reliability and affordability aspect of its energy security. Specifically, Chinese concerns are concentrated in two regions-the Middle East and Central Asia. According to Zhu Xingshan, deputy director of the Economic Center of Energy Research Institute under the NDRC, following September 11 there were two possibilities that could lead to a new oil crisis. ${ }^{95}$ First, Arab countries could form a new alliance and use oil as a weapon to boycott and limit oil production to fight against the United States. Second, new retaliatory terrorist attacks could be launched on the United States or on main oil transportation lines and major oil facilities, thereby cutting off oil supplies to China. Should any of these two possibilities materialize, reliable oil supply to China from the Middle East would be interrupted and resultant high oil prices would inflict strong pressure on the Chinese economy.

In addition to concerns about oil security in the Middle East, China is also worried about the US military presence in Afghanistan and Central Asia after September 11. For one thing, many Chinese strategists take US military bases in Central Asia as evidence of a US attempt to encircle China. Prior to September 11, China had been seeking to reduce its reliance on oil shipments through the Malacca Strait by trying to build oil pipelines from Russia and Central Asia. But the increased US military presence in the region, in the Chinese view, counteracts any additional control over its oil imports reliability. Some Chinese such as Mr. Zhu from the NDRC have gone even further to suggest that "the terrorist attacks on September 11 have objectively provided a pretext for the United States to enter Central Asia in a way to complicate an environment which originally was straightforward for China. This will be of far-reaching significance to the strategy of oil supply in China." ${ }^{\text {, }}$

\section{Case 2: How does the War in Iraq affect China's energy security?}

Although China only imported $0.8 \%$ of its total oil from Iraq in 2002, the war in Iraq took place in a region from which it imported 70,000 barrels of oil per day, which accounted for half of its oil imports in that year. Moreover, Iraq sits on the third largest deposit of oil reserves in the world. Hence, the Chinese

\footnotetext{
${ }^{94}$ Qin Xuanren, “Guoji da huanjing ji daguo nengyuan waijiao yunchou,” (The International Environment and the Diplomatic Energy Strategies of the Major Powers), Guoji shiyou jingji (International Petroleum Economics), Vol. 12, No.1, 2004, p. 36; Also see Zhang Youguo, "Zhongya liyi geju zhong de meiguo yu zhongguo,” (USA and China in the Central Asian Interests Pattern), Dongbeiya luntan (Northeast Asia Forum), Vol.13, No.3, May 2004, p. 24.

${ }^{95}$ Discussion of China's perceptions about impact of the 9/11 attacks on China's oil security is based on "US 'Attacks September 11' Focusing on China's Oil Security,” People's Daily Online, Internet version, available at http://english.people.com.cn/english/200109/21/eng20010921_80742.html, September 24 2001, accessed August 16, 2005.

96“"US ‘Attacks September 11' Focusing on China’s Oil Security,” People’s Daily Online, Internet version, available at http://english.people.com.cn/english/200109/21/eng20010921_80742.html, September 24 2001, accessed August 16, 2005.
} 
energy analysts followed the war very closely and were extremely concerned about its repercussions for China's oil security.

In fact, most Chinese analysts believe that the war in Iraq was motivated by a US desire to control oil resources in the Middle East; ${ }^{97}$ as such it affected all three aspects of China's oil security. First, it changed the availability of China's oil imports both in the short term and long term. In the short term, it wiped out China's hopes of developing large assets in Iraq. China had been waiting for the end of sanctions to begin work on the Al-Ahdab field in Central Iraq, under a \$1.3 billion contract signed in 1997 by CNPC. The field's production potential has been estimated at 90,000 barrels a day. In addition, China was also pursuing rights to a far bigger prize — the Halfayah field, which could produce 300,000 barrels a day. ${ }^{98}$ Together, the two fields might have delivered up to 17\% of China's 2004 total imports. In the long term, many Chinese analysts believe the war in Iraq will expand America's influence and control over the Middle East to the fullest extent, thus limiting China's access to Iraqi oil resources. According to a Chinese scholar,

After the Iraq War, the United States not only obtained control over Iraqi oil resources and strengthened its influences over other Persian Gulf oil producers but also improved its ability to contain Iran, which is China's second largest oil exporter. On the other hand, the US occupation in Iraq would give US and British oil capita easier access to Iraq's rich oil resources. In addition, they will find it painless, under a pro-American government in Iraq, to squeeze or exclude China's access to Iraqi oil resources and limit the diplomatic space within which China can maneuver in the country. As a result, our oil security will be subject to U.S. influences and control for quite a while. ${ }^{99}$

Second, in the view of Chinese the war in Iraq negatively influenced the reliability of China's oil imports from the Middle East. The concern is plainly demonstrated by the title of a special report run by the CCP's house organ People's Daily “The suspense of the US war against Iraq: will the 70,000 barrels of oil from the Middle East be shipped safely to China?”"100 Evidently, China is concerned that the war in Iraq might interfere with the availability of the country's oil imports from Iraq or other countries in the Middle East.

Third, Chinese analysts were of the view that the war in Iraq threatened the affordability of China's oil imports. High oil prices increased China's financial burden from increased oil imports. To pre-empt the possible negative impact of the war in Iraq on China's oil availability, the country imported 83.6 million tons of oil in January 2003 alone, registering an increase of $77.2 \%$ compared to the same time in the

\footnotetext{
${ }^{97}$ Qin Xuanren, “Guoji da huanjing ji daguo nengyuan waijiao yunchou,” (The International Environment and the Diplomatic Energy Strategies of the Major Powers), Guoji shiyou jingji (International Petroleum Economics), Vol. 12, No.1, 2004, p. 35; also see Wu Lei, "Yilake zhanzheng dui woguo shiyou anquan de yingxiang" (The Impact of the Iraq War on Our Oil Security), Guoji luntan (International Forum), Vol.5 No.4, July 2003, p.28; Shu Xianlin and Yan Gaocheng, "Shiyou: zhongguo nengyuan anquan de hexin yu guoji zhanlue” (Oil: The Core of China's Energy Security and China's International Strategies), Shiyou huagong jishu jingji (Journal of Petrochemical Technology and Economics), Vol.20, Issue. 3, 2004, p. 14.

${ }^{98}$ Peter S. Goodman, “Big Shift in China’s Oil Policy,” Washington Post, July 13 2005, p. D01.

${ }^{99}$ Wu Lei, "Yilake zhanzheng dui woguo shiyou anquan de yingxiang” (The Impact of the Iraq War on Our Oil Security), Guoji luntan (International Forum), Vol.5 No.4, July 2003, p.30.

${ }^{100}$ Li Yige, "Meiyi zhanzheng xuannian: 70 wantong shiyou nengfou anquan yundi zhongguo" ("The Suspense of the American War against Iraq: Will the 70,000 Barrels of Oil Be Shipped to China Safely?”) People's Daily, Online Edition, available at http://past.people.com.cn/GB/Jinji/20030219/926361.html, accessed August 4, 2005.
} 
previous year. However, thanks to high oil prices, oil imports cost China $51 \%$ more than the same time in the previous year, with a net increase of $\$ 1.01$ billion, which largely contributed to the country's trade deficits in the first month of the year. On another account, the Chinese were also concerned that the number of oil tankers running from the Persian Gulf would drop as a result of the war in Iraq or increase their insurance premiums. Since 93\% of China's total oil imports are shipped by sea, of which more than $90 \%$ is shipped by international tankers, increases in shipment costs or insurance premiums were perceived to be inimical to the Chinese economy. In fact, according to the People's Daily, as a result of high oil prices, the country's GDP growth slumped by $0.5 \%$ in $2000 .{ }^{101}$ Moreover, Chinese officials also worried that the rising oil prices caused by the war in Iraq would slow down other economies in the world, which would in turn reduce their purchasing power for Chinese exports. Trade contributes $80 \%$ of the country's total GDP.

Exacerbated by the lack of SPRs, oil futures market, and a capable navy that can cushion the Chinese economy against various price or supply shocks, the sense of oil insecurity was elevated soon to the top leadership's attention. To prepare the economy for negative fallouts from the war in Iraq on its oil security, in March 2003 the government re-opened Chinese oil wells sealed before due to their relatively high production cost. On May 26, 2003 the Chinese premier Wen Jiaobao listened to a report made by a research group from the Chinese Academy of Engineering, and decided in that very meeting to officially launch a strategic study of the sustainable development of oil and gas. The study was assigned to a research group comprising 151 experts from different government agencies and big state owned energy companies. As an indication of the top leadership's attentiveness to this strategic study, Premier Wen held two more study sessions-one in October 2003 and one on June 24, 2004 after the study was completed. Although China began studying oil and gas strategy a long time ago, it was the first time that the premier personally guided and directed the study. This reflects the great importance that the Chinese authorities attach to the strategy of developing oil and gas resources. Nonetheless, this only represents one of many steps that the Chinese government has taken to enhance its energy security, to which we now turn.

\subsection{How does China respond to its energy insecurity?}

To enhance the country's energy security, the Chinese government has taken multi-pronged measures to tackle different sources of its insecurity. Many of these measures were taken separately to solve one particular dimension of the country's energy insecurity, but increasingly the Chinese government has embarked on various medium- or long-term comprehensive national energy strategies against the background of restructuring the country’s energy policy making system.

\subsection{China's responses to cyclical insecurity}

First, to alleviate the country's cyclical energy insecurity, namely power shortages, the Chinese government has taken steps both on the supply side and demand side. On the supply side, the Chinese government has been rapidly adding installed power generation capacity, with 50 million kilowatts added in 2004 and 70 million kilowatts to be added each year from 2005 to $2007 .{ }^{102}$

\footnotetext{
${ }^{101}$ Liao Hong and Chen Yun, “Tebie cehua: duiyi zhanzheng zhongguo jingji sunshi you duoda?” (Special Report: What Are China's Economic Losses as a Result of the Iraq War), People's Daily, Online Edition, available at http://past.people.com.cn/GB/jinji/31/179/20030225/930064.html, accessed August 4, 2005.

102 “China to build 1st offshore wind power plant,” Xinhua News Agency, Online Edition, available at http://news.xinhuanet.com/english/2005-08/13/content_3347591.htm, August 13 2005, accessed August 26, 2005.
} 
Additionally, the government has started seriously to promote renewable energy use. As shown by Table 11 , China sees renewable energy as a significant resource. However, for years the lack of a regulatory framework and financial support has limited the scale of renewable energy's energy contribution to China's total energy consumption. Currently, renewable energy only accounts for 3\% of China's total energy consumption. Power shortages, however, really highlight the potential contribution of renewable energy. Thus, on February 28, 2005, the National People’s Congress (NPC) passed the Renewable Energy Law, legalizing the regulatory framework for China's renewable energy development and providing economic incentives and financial support to the R\&D, construction and use of renewable energy facilities. In the meantime, the Chinese government also drafted long-term renewable energy development strategies, according to which $10 \%$ of the country's total energy consumption will come from renewable energy sources by $2010,18 \%$ by $2020,30 \%$ by 2030 , and $50 \%$ by $2100 .{ }^{103}$ To achieve these long-term targets, the government also taps into foreign capital. On June 16, 2005, the World Bank’s Board of Executive Directors approved a US \$87 million loan to China for the financing of the Renewable Energy Scale-Up Program, supplemented by a grant of US \$40.22 million from the Global Environment Facility (GEF) to induce an increased capacity of renewable electricity of more than 20 gigawatts. ${ }^{104}$ The Project's objective is to expand renewable electricity supply in China efficiently, cost effectively, and on a large scale.

Table 11. China's recoverable renewable energy reserves ${ }^{105}$

\begin{tabular}{|l|l|}
\hline \multicolumn{1}{|c|}{ Source } & \multicolumn{1}{c|}{ Recoverable reserves } \\
\hline Hydropower & 378 million kilowatts \\
\hline Land wind power & 250 million kilowatts \\
\hline Ocean wind power & 750 million kilowatts \\
\hline Ocean energy & 200 million kilowatts \\
\hline Solar energy & 170 billion tons of standard coal \\
\hline
\end{tabular}

Another strategy the Chinese government has taken on the supply side is to expand nuclear power generation. China currently has nine nuclear power plants under operation and a further two under construction, with a total installed capacity of 7.01 million kilowatts. ${ }^{106}$ According to official statistics,

\footnotetext{
${ }^{103}$ Zhang Zhengmin, Wang Gehua, and Gao Hu, “Zhongguo ke zaisheng nengyuan fangzhan zhanlue yu zhengce yanjiu,” (The Study of China’s Renewable Energy Development Strategy and Policy), Jingji cankoa yanjiu (Economic Research and Reference), 2004 No.84, pp.26-32.

104 “China: World Bank To Help Scale Up Use Of Renewable Energy,” The World Bank, available at http://web.worldbank.org/WBSITE/EXTERNAL/COUNTRIES/EASTASIAPACIFICEXT/EXTEAPREGTOPENV IRONMENT/0,,contentMDK:20545709 menuPK:502932 pagePK:34004173 piPK:34003707 theSitePK:502886, 00.html, accessed August 20, 2005.

105 Gong Juping, "Ke zaisheng nengyuan: zhongguo weilai fazhan de yinqing” (Renewable Energy: The Engine of China’s Future Development"), Zhongguo chuangye tongzi yu gokeji (China Venture Capital and High-Tech ),

2005 No.1, carried by The China Scientific and Technical Information System, available at http://www.chinainfo.gov.cn/data/200505/1_20050510_109991.html, May 10 2005, accessed August $29,2005$.

106 “China to Speed Up Nuclear Power Construction,” People’s Daily Online, available at http://english.people.com.cn/200409/02/print20040902_155614.html, accessed July 192005.
} 
nuclear plants in China, which make up $1.7 \%$ of the total installed power generation capacity in the country, produced 43.8 billion kilowatt hours of electricity last year, accounting for $2.29 \%$ of the country's total power output. ${ }^{107}$ To expand its nuclear capacity, the country plans to spend 400 billion yuan—nearly $\$ 50$ billion—on 30 more nuclear reactors within the next 15 years. By 2020, China aims to have a total nuclear installed capacity of 40 gigawatts, almost doubling its share of total power output to $4 \%{ }^{108}$

On the demand side, the government tries to encourage energy conservation through both administrative measures and market incentives. While China's Energy Conservation Law entered into force on January 1, 1998 it failed to promote energy conservation. Thanks to the latest round of power shortages, energy conservation comes back to the agenda again. This time it attracts both the local and central leadership's attention. To combat power shortages in the summer of 2004, Shanghai, one of the hardest hit areas in China, ruled that air conditioners in all shopping malls, offices and hotels are not allowed to be set lower than $26^{\circ} \mathrm{C}\left(79^{\circ} \mathrm{F}\right)$. In addition, the city will use 400,000 energy-saving bulbs in schools and other places throughout the summer. Meanwhile, the NDRC drafted "The China Long and Medium-Term Energy Conservation Plan,” effective from November 2004 to 2020. According to the conservation plan, all the buildings built after 2006 are required to embrace new technology and methods that could save $50 \%$ of the energy consumption per square meter compared to now. ${ }^{109}$ Furthermore, by 2010, China aims to consume 2.25 tons of standard coal when producing 10,000 yuan $(\$ 1,200)$ of GDP per capita, 0.43 tons fewer than that of 2002 and by 2020, to consume 1.54 tons of standard coal. ${ }^{110}$

To realize the goal set by the conservation plan, the Chinese government also turns to foreign assistance. In June this year, the Chinese government launched an $\$ 80$ million program with the United Nations to promote efficient use of energy. It will focus on the industrial and construction sector first as they two take up the bulk of China's energy consumption. The program aims to reduce energy consumption by nearly 19 million tons of coal equivalent in the first three-year phase of the program. ${ }^{111}$ Then, energy efficiency standards and labeling for electrical goods in the residential and service sectors - ranging from refrigerators to air conditioners - would also be phased in over three years.

In addition to administrative measures, the government also resorts to market mechanisms to encourage investment in the power sectors, induce energy conservation, and discourage overinvestment in energyintensive industries. Over the last two years, the Chinese government has raised electricity prices twice. On June 15, 2004, China raised the average price of electricity by 0.022 yuan ( 0.3 cents) per kilowatt/hour in south, east, central, and north China. Higher prices were adopted for peak time electricity consumption in Shanghai, Beijing, Tianjin, Hebei, Jiangxi, and Chongqing. Similarly, in Jiangsu, Hunan, and Henan provinces, electricity suppliers and distributors have coordinated their pricing movement at peak and off peak-periods. Moreover, to rein in the blind expansion of those energy-intensive industries, the government decided to adopt differentiating power prices for six raw material sectors: aluminum,

\footnotetext{
107 “China to Speed Up Nuclear Power Construction,” People’s Daily Online, available at http://english.people.com.cn/200409/02/print20040902_155614.html, accessed July 192005. 108 Ibid.

109 “China Launches Energy-Saving Plan for Coming 15 Years,” People’s Daily Online, available at http://english1.people.com.cn/200411/26/print20041126_165221.html, November 26 2004, accessed July 5, 2005.

110 “China Launches Energy-Saving Plan for Coming 15 Years,” People's Daily Online, available at http://english1.people.com.cn/200411/26/print20041126_165221.html, November 26 2004, accessed July 5, 2005. 111 “China Launches 80 Million Energy Efficiency Program,” Xinhua News Agency, Online Edition, available at http://news.xinhuanet.com/english/2005-06/08/content_3058080.htm, June 8 2005, accessed July 52005.
} 
ferroalloy, calcium carbide, caustic soda, cement and steel. An extra 0.02 yuan or 0.05 yuan $(0.2$ or 0.6 cents) per kilowatt hour will apply to enterprises that fail to meet the requirement of national industrial policy. On May 1, 2005, in the face of the huge power shortages, the government again increased electricity prices for industrial and commercial users by another 0.3 cents per kilowatt hour.

\subsection{China's responses to environmental insecurity}

Both the renewable energy development goal and the energy efficiency program are geared to provide more power and save energy as well as help enhance China's environmental security. For example, China's Renewable Energy Scale-Up program under the support of the World Bank over three years is expected to reduce carbon emissions by about 800 million tons, total suspended particulate emissions by more than 800 million tons, sulfur dioxide emissions by more than 30 million tons , and nitrogen oxides emissions by more than 6 million tons. ${ }^{112}$ Similarly, the 80 -million-dollar energy efficiency program China recently launched is expected to cut carbon emissions by 12 million tons. ${ }^{113}$

Alarmed by the mammoth impacts of China's economic growth on resource depletion and environmental pollution, the central government began in 2003 to implement the concept of scientific development, seeking coordinated economic, social, and environmental development. To echo that theme, the State Environmental Protection Bureau (SEPA) and the State Statistical Bureau (SSB) have been jointly working on the criteria and indexes of a green GDP, which deducts the costs of environmental damage and resources consumption from traditional gross domestic product when governments of all levels calculate economic development. The "green GDP" will be created in three sequences, with the first step involving the quantity of natural resources consumed in economic activities, the second step the quantity of environmental loss caused by economic development, and the last step the value of the natural resources and environmental loss. According to an official report, a framework will be ready for calculating the green GDP throughout the country in three to six years. ${ }^{114}$ In fact, ten municipalities and provinces, Beijing, Tianjin, Chongqing, Hebei, Liaoning, Zhejiang, Anhui, Guangdong, Hainan and Sichuan, have been selected in the pilot program to start taking environmental costs into account when calculating their GDP at the local level.

Meanwhile, the country has expanded its investment in environmental protection both at the local and central government level. At the local level, for example, Shanghai invested 50 billion yuan (about 6 billion US dollars) in environmental protection between 1992 and 2000, or 2.8\% of the city's GDP. ${ }^{115}$ Similarly, Beijing will spend 92.7 billion yuan (more than 11 billion US dollars) in preventing and treating environmental pollution between 2003 and 2007. ${ }^{116}$ At the national level, the Chinese government

\footnotetext{
112 “China: World Bank To Help Scale Up Use Of Renewable Energy,” The World Bank, available at http://web.worldbank.org/WBSITE/EXTERNAL/COUNTRIES/EASTASIAPACIFICEXT/EXTEAPREGTOPENV IRONMENT/0,,contentMDK:20545709 menuPK:502932 pagePK:34004173 piPK:34003707 theSitePK:502886, 00.html, accessed August 20, 2005.

113 “China Launches 80 Million Energy Efficiency Program,” Xinhua News Agency, Online Edition, available at http://news.xinhuanet.com/english/2005-06/08/content_3058080.htm, June 8 2005, accessed July 52005.

114 "Raising Awareness of 'Green GDP',” China Internet Information Center, available at http://www.china.org.cn/english/environment/119572.htm, accessed August 30, 2005.

115 “Shanghai Increases Investment in Environmental Protection,” People's Daily, Online Edition, available at http://english.people.com.cn/english/200007/28/print20000728_46700.html, July 28 2000, accessed August 26, 2005.

116 “Beijing to Spend More on Pollution Control,” China Internet Information Center, available at http://www.china.org.cn/english/envrionment/56355.htm, February 21 2003, accessed August 30, 2005.
} 
has increased spending. To achieve the goal set by the "Tenth Five-Year Plan for State Environment Protection,” the Chinese government allocated 700 billion yuan (more than 80 billion US dollars), accounting for 1.3\% of GDP between 2001 and 2005 or 3.6\% of the gross volume of fixed investment of the whole society. ${ }^{117}$

\subsection{China's responses to oil insecurity}

To reduce its oil insecurity, the Chinese government has been taking a series of steps to tackle the three culprits, namely the lack of availability of oil, limited reliability and affordability of its oil imports. Because China has perceived oil insecurity as its greatest vulnerability in the energy security situation, leaders have focused efforts on expanding oil security policies.

\subsubsection{China's responses to the lack of availability of oil}

China has adopted a multi-faceted strategy to increase availability of both domestic and foreign oil. On the domestic front, the country has began searching for new oil fields to replace those in the east, particularly Daqing Oil Field (Fig. 13). Two thirds of China's oil fields are concentrated in East China (Fig. 14), but the majority are characterized by high water-oil ratio (88\%), high production-reserve ratio (75\%), and high exploitation speed. ${ }^{118}$ As a result, production starts to decline. One good case in point is the country's top oil field—Daqing Oil Field. After supplying the country with more than 50 million tons of oil annually for more than 27 years, Daqing failed to keep that record for the first time in 2003. The decline in production points to the evidence that the oil field has reached its peak. In fact, ever since 1997, as Figure 7 indicated, its production has been declining at an average speed of $2.6 \%$ per year. Although it still provides roughly one third of China's total oil supply, according to official estimates, its production will rapidly fall to 20 million tons per year by 2010. To fill the gap left by Daqing Oil Field, the country has focused on two potential areas for new discoveries, Xinjiang's Tarim Basin (Fig. 14) and offshore areas.

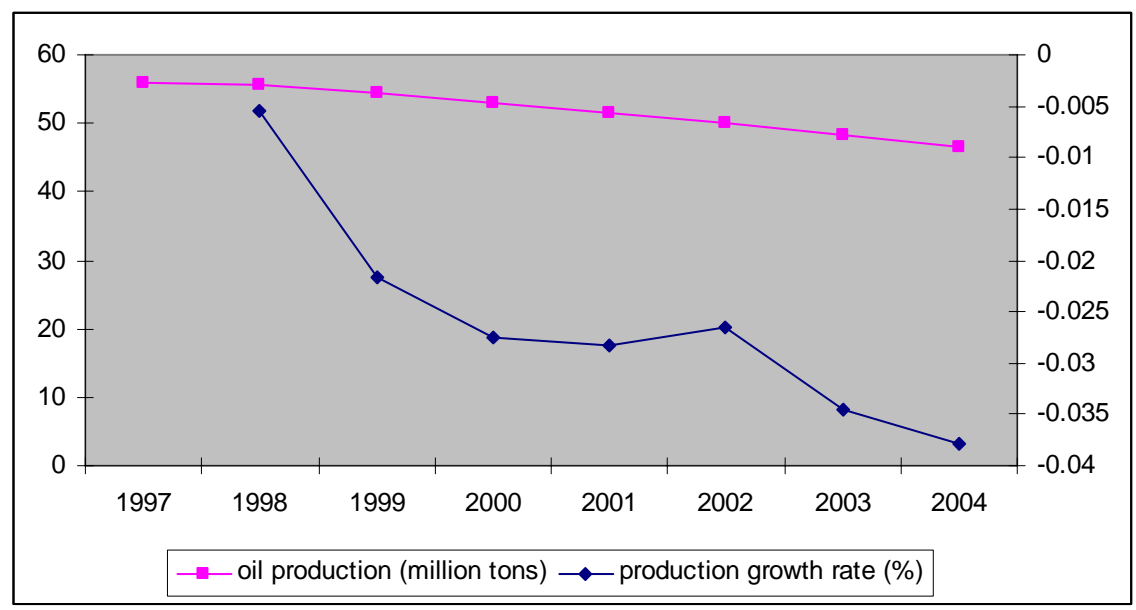

Figure 13. Daqing Oil Field’s Oil Production 1997-2004 ${ }^{119}$

\footnotetext{
117 “China to Invest 700 Billion Yuan for Improving Urban and Rural Environment,” People’s Daily, Online Edition, available at http://english.people.com.cn/200201/31/print20020131_89701.html, January 31 2002, accessed August 30, 2005.

118 Liu Lili, “Zhouguo shiyou fazhan zhanlue yanjiu” (Researching China’s Oil Development Strategy, Shiyou daxue хиеbao(Journal of the University of Petroleum), Social Sciences Edition, Vol. 20, No. 1, February 2004 , p.2. ${ }^{119}$ Wang Qingyi, “Zhongguo yu shijie nengyuan shuju” (“Data on China and the World's Energy”), Meitan jingji yanjiu (Journal of Coal Economics Study), Vol.2, 2004, p.75; 2003 Daqing City Economic and Social Development
} 


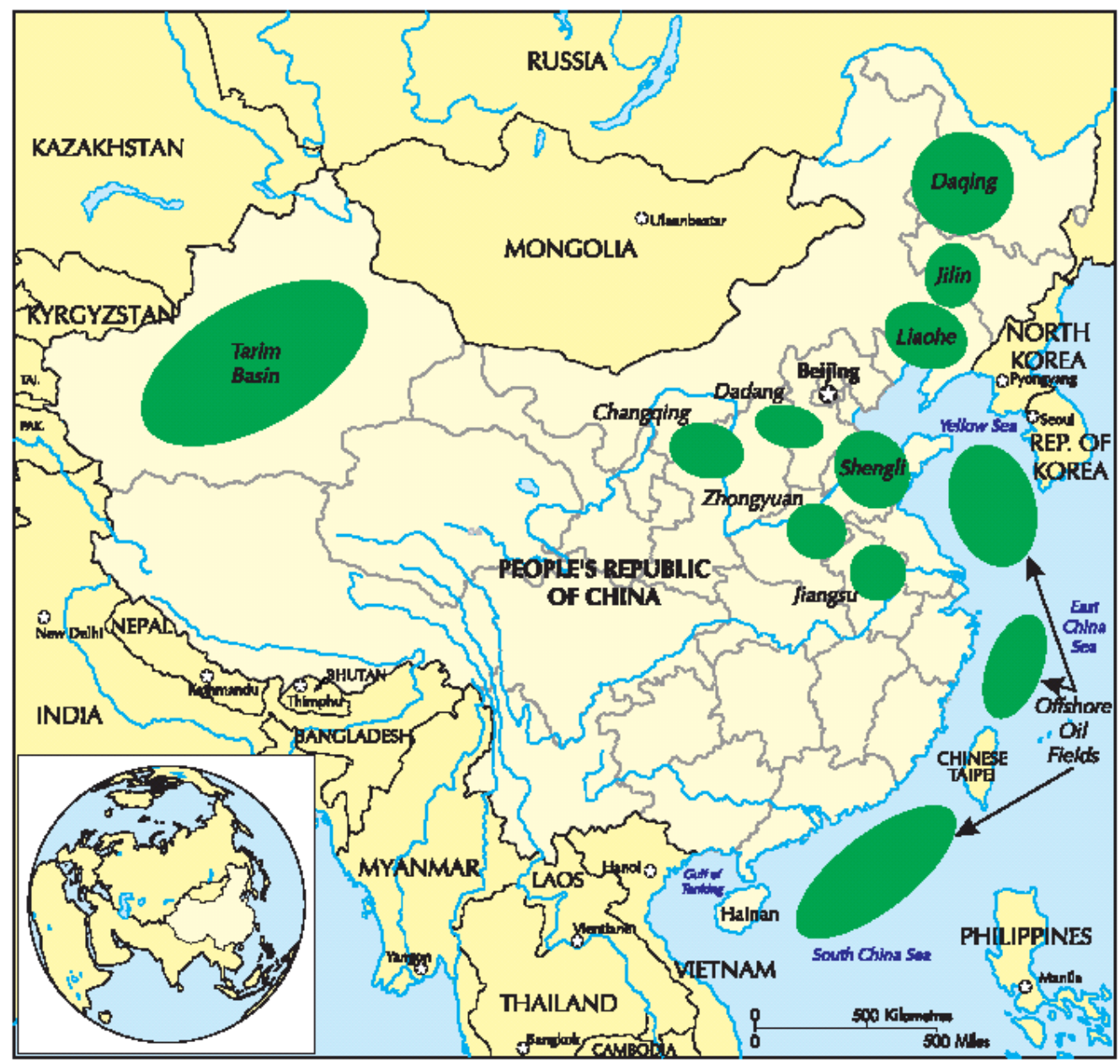

Source: China Oil, Gas\& Petrochemicals

Figure 14. China's oil fields

Both places are said to be rich in oil and gas. According to official data, in Xinjiang the Tarim Basin, Junggar Basin, and Turpan-Hami Basin all together boast 20.9 billion tons of oil and 10 trillion cubic meters of natural gas, accounting for $30 \%$ of the country's oil reserves and $34 \%$ of its gas reserves. ${ }^{120}$ As such, Xinjiang is nicknamed the "Sea of Hope." Currently, Xinjiang is China's third largest oil supplier, providing $12.7 \%$ of the country's total production. Trying to enhance its strategic importance and ride on the oil boom, local governments in Xinjiang are pushing oil production to 50 million tons per year by 2010. However, as Figure 15 indicates, the average growth rate of oil production in Xinjiang hangs around $4.6 \%$, calling into question the officially projected rate of production increase. Having said that, at the current growth rate, by 2010 Xinjiang can easily supply the country with 30 million tons of oil if not 50 million tons. Added to oil imports from Central Asia, Xinjiang will replace Daqing as China's most important energy base.

Statistical Communiqué, July 14, 2005, and 2004 Daqing City Economic and Social Development Statistical Communiqué, July 5 2005, published by Daqing Municipal Government, available at http://www.daqing.gov.cn/daqinggov/73754140479586304/index.shtml, accessed August 31, 2005

120 “Xinjiang Plans to Be China’s Top Oil Producer,” People’s Daily, Online Edition, available at http://english.people.com.cn/200506/14/eng20050614_190148.html, June 14 2005, accessed August 31, 2005. 


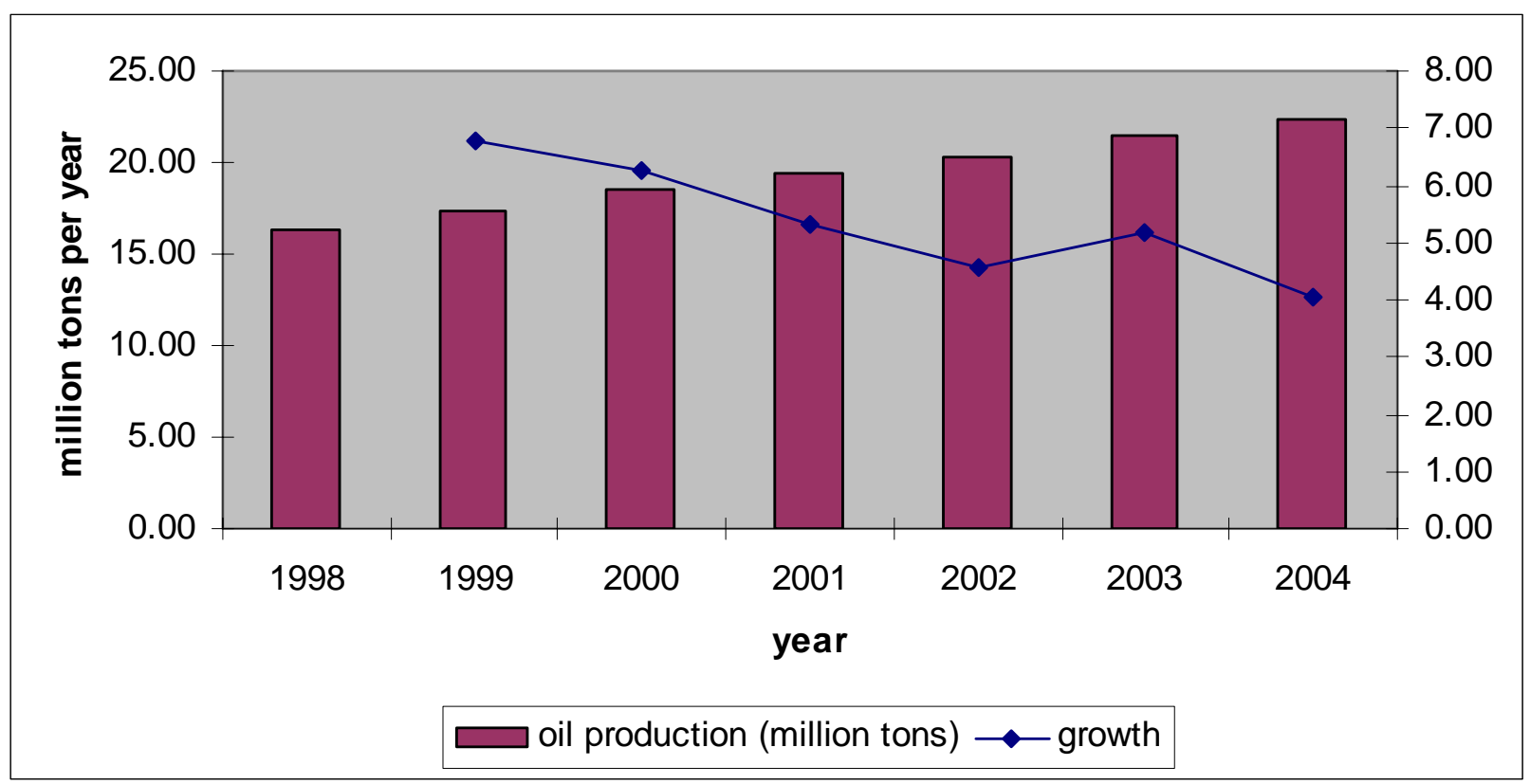

Figure 15. Xinjiang’s Oil Production, 1998-2004 ${ }^{121}$

Similarly, offshore production (Fig. 16) has been rekindling the government's hope to reduce dependence on foreign oil. As shown by Figure 17, offshore oil production has been growing at $15.3 \%$ per year on average, with production level reaching 28.4 million tons in the year of 2004 and accounting for 16.2\% of China's total domestic supply. The recent expansion of offshore production only marks the first step of China's new initiative to conduct more exploration and production in its offshore areas, which according to official statistics could produce 24 billion tons of oil and 14 trillion cubic meters of natural gas. ${ }^{122}$ To better coordinate the offshore energy development, on May 9, 2003, the Chinese government issued for the first time in history “Outlines of National Marine Economy Development Plan,” providing a regulatory framework and long-term guidance.

Meanwhile, the country exempts import duties on equipment or technology to be used in offshore oil exploration and production. As a result, for the first nine months this year Tianjin port saw imports of offshore oil production equipment worth 250 million US dollars, 76.8\% higher than the same time last year. Based on the growth in offshore production and tons of capital flowing into the sector, the Chinese government hopes to double the offshore oil production to 67 million tons by 2010, making it China's largest source of oil supply.

\footnotetext{
${ }^{121}$ Data obtained from various years of Statistical Communiqués published by Statistical Information Network of Xinjiang China, available at http://www.xj.stats.gov.cn/tjgb/tjgb.htm, accessed August 30, 2005.

${ }^{122}$ Quanguo haiyang jingjin fazhan guihua gangyao (Outlines of National Marine Economy Development Plan), State Oceanic Administration People's Republic of China, May 9 2003, available at http://www.soa.gov.cn/hyjj/index.html, accessed August 30, 2005.
} 


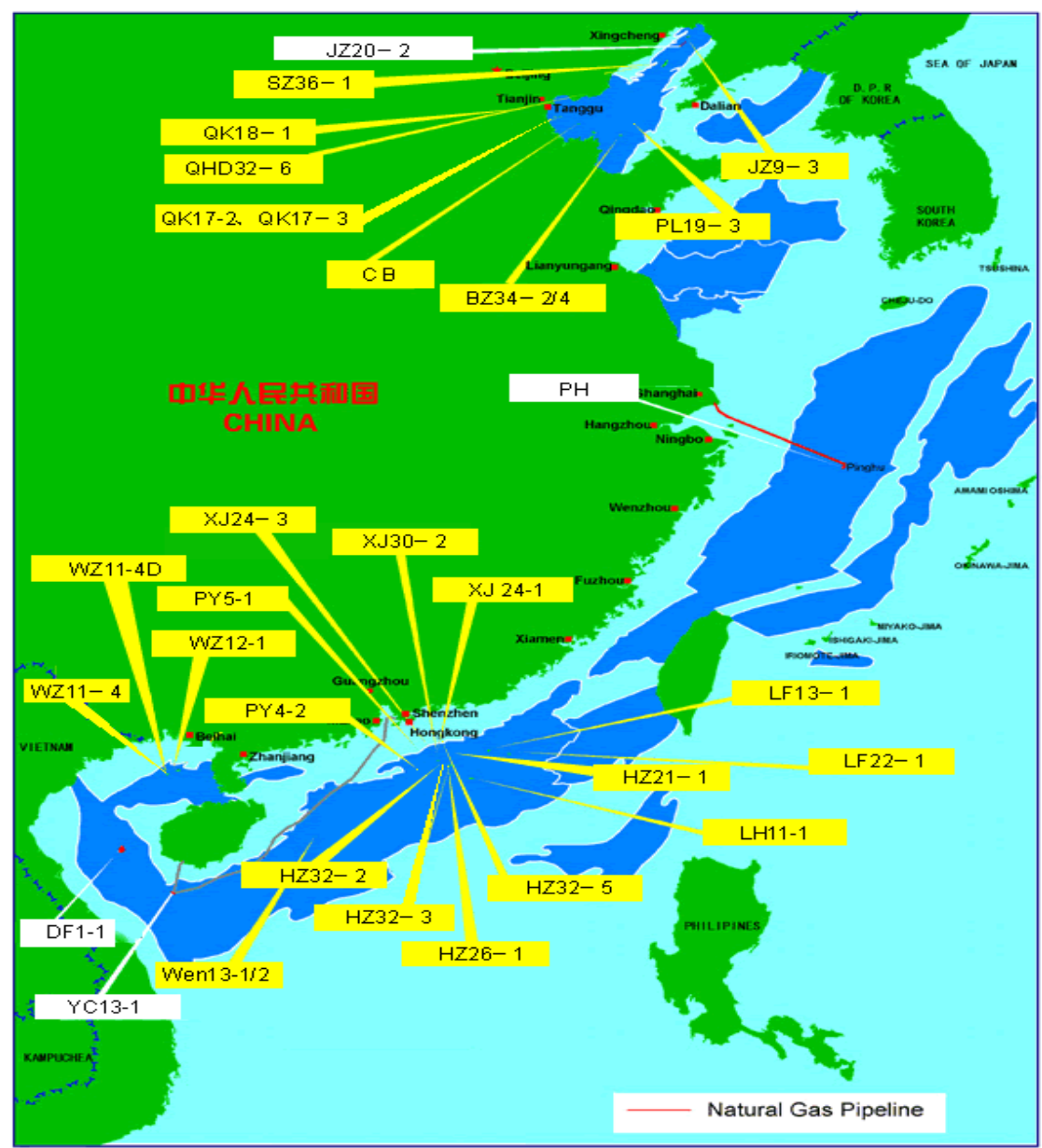

Source: CNOOC website

Figure 16. Map of China's off shore oil and gas fields

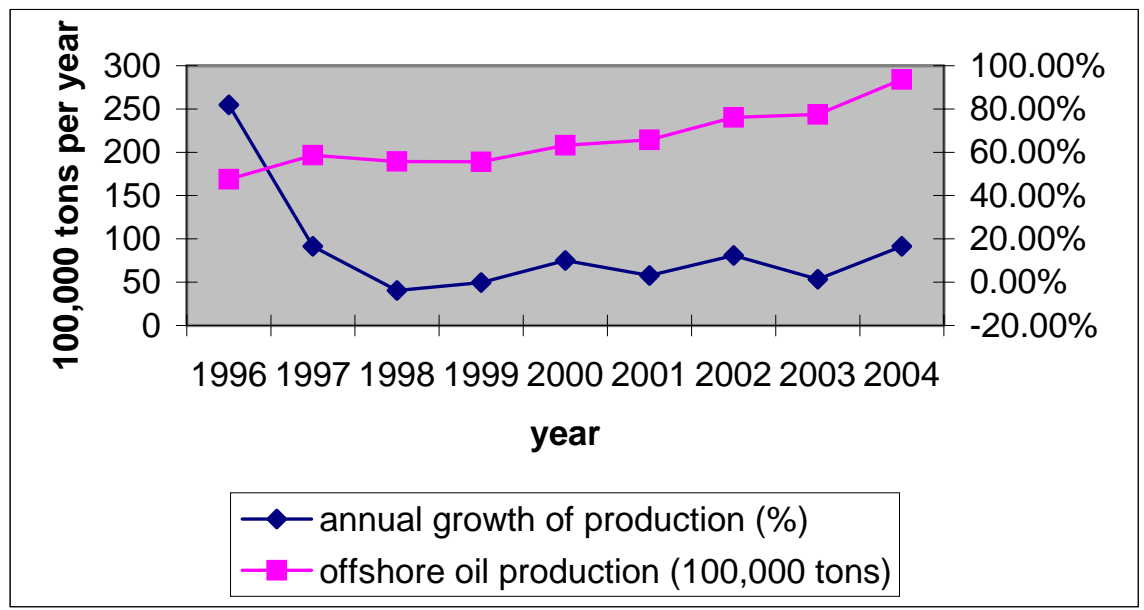

Figure 17. China's offshore oil production, $1996-2004^{123}$

${ }^{123}$ State Oceanic Administration People's Republic of China, 2003 nian zhongguo haiyang jingji tongji gongbao, 2004 Statistical Communiqué of China’s Marine Economy (2003 Statistical Communiqué of China’s Marine 
Other than conducting more exploration and production, the Chinese government also encourages alternatives to oil by not only promoting gas consumption but also boosting research in energy R\&D. On one hand, gas has been put on equal footing in China's energy development strategy. This is evidenced by the construction of the 4000-kilometer-long west-to-east gas pipeline that can bring 12 billion cubic meters of natural gas to the east coast and liquefied natural gas (LNG) terminals along the east coast. Two terminals are particularly worth mentioning. The first is located in Guangdong Province and receives 3 million tons of LNG annually for 25 years beginning this year from Australia, while the second sits in Fujian Province and will take delivery of 2.6 million tons of LNG annually from Indonesia starting in 2007 under a 25-year-long contract. Nonetheless, two is just the very beginning and more are coming along the coast. Jiangsu, Zhejiang, Liangning, Hebei, and Shangdong provinces, and Shanghai are all considering building LNG terminals and will have them soon.

On the other hand, China has been making strides in researching new technology that can offer substitutes to conventional oil. In particular, China has been taking the lead in coal liquefaction, hydrogen, and fuel cell research. Coal liquefaction started in China more than 20 years ago, but the costs involved to liquefy coal have prevent the sector from receiving large financial inflows, thus limiting its scale. However, growing dependence on foreign oil and high oil prices revived interest in coal liquefaction research. On August 25, 2004, the state-owned flagship company Shenhua Group started to build the world's first commercially oriented direct coal liquefaction project, costing 3.3 billion US dollars, in Inner Mongolia using Shell-licensed technology. According to the official report, this project is expected to begin operation in 2007, with the capacity to convert five million tons of coal to one million tons of oil products per annum. ${ }^{124}$ Meanwhile, two more liquefaction bases, with one in Shaanxi and the other one in Ningxia, are also conducting intensive research. With all the production potential realized, according to an official estimate, $10 \%$ of China's oil imports will have been replaced by coal-liquefied oil by $2013 .{ }^{125}$

Similarly, China has been making progress in hydrogen and fuel cells research as well. In fact, China has listed rational use of hydrogen in its energy development strategy and increased investment for research of automobiles powered by hydrogen cells. The Ministry of Science and Technology set aside over 400 billion yuan (about 48.2 million US dollars) for research on hydrogen cell-driven automobiles from 2001 to 2005. To coordinate the research, Shanghai and Beijing were assigned the task of developing hydrogen-powered sedan cars and buses respectively, and they have worked out the second-generation automobiles. For example, China has already developed fuel cell engines with a net output of 40 kilowatts for electric sedans and of 100 kilowatts for urban passenger cars, making China's fuel cell technology one of the most advanced in the world. ${ }^{126}$ The medium-term goal is that hydrogen-powered automobiles will be in service during the Beijing 2008 Olympic Games and the World Expo scheduled to be held in Shanghai in 2010. Needless to say, if hydrogen and fuel cells can be substituted for oil in transportation, the largest car market to be will be relieved of the ever increasing pressure to look for more oil to keep cars on the road.

Economy), 1996-2002 nian woguo haiyang jingji fazhan zongshu (Synopsis of China’s Marine Economic Development, 1996-2002), available at http://www.soa.gov.cn/hyjj/index.html, accessed August 30, 2005.

124 “China's First Coal Liquefaction Scheduled to Ease Import Burden,” People’s Daily, Online Edition, available at http://english.people.com.cn/200501/24/print20050124_171675.html, January 24, 2005, accessed August 292005.

125 “China's First Coal Liquefaction Scheduled to Ease Import Burden,” People’s Daily, Online Edition, available at http://english.people.com.cn/200501/24/print20050124_171675.html, January 24, 2005, accessed August 292005.

126 “China’s Fuel Cell Technology Advanced in the World,” People’s Daily, Online Edition, available at http://english.people.com.cn/200508/02/print20050802_199835.html, August 2, 2005, accessed August 292005. 
In addition to measures revolving around the supply side of the equation, China has also taken steps on the demand side to address the availability aspect of China's oil insecurity. One particular effort the Chinese government made to curb oil consumption was to impose high fuel efficiency standards on automakers, domestic and foreign, compelling them to produce cars that consume less oil and to introduce the latest hybrid engines and other technology in China. On July 1, 2005, China entered into Phase I of its fuel efficiency standard, during which Chinese passenger vehicles are required to meet the current level of Chinese-made passenger vehicles in terms of fuel consumption. In the second stage starting from January 1, 2008, vehicle's fuel consumption must drop by $10 \%$ from the first stage level. These new standards are based on a vehicle's weight - the lighter ones must go farthest on a gallon —and on the type of transmission, with small manual-shift cars going farther than those with less efficient automatic transmissions. Comparatively, the standards are more stringent than those in the United States. First, the Chinese standards, in general, will call for new cars to get up to two more miles a gallon of fuel than the average allowed in the Untied States; for sport utility vehicles, the Chinese minimums would be 1.7 to 2.7 miles per gallon higher than U.S. averages. ${ }^{127}$ Second, American standards are fleet averages whereas the Chinese standards are minimums for each vehicle. In other words, an American manufacturer can sell vehicles in the United States that are far below average in fuel efficiency it if has others in its product line that offset it by being above average. Under the Chinese rules, however, every vehicle of the same model has to meet the requirement after the standards take effect. By implementing these tough standards, the Chinese government hopes to reduce oil consumption by steering consumers toward more fuel efficient cars without having to make the painful decision to slow down the expansion of China's fast growing auto industry, which has been one of the engines of the Chinese economic growth in the past four years. According to an official estimate, if executed on schedule, these fuel efficiency standards would save $18 \%$ of total oil consumption by 2008 . $^{128}$

One more policy on the demand side under deliberation is a fuel tax. The Chinese government has been reluctant to push it through because of concerns about its implications for the rural population and taxi drivers. A fuel tax might hurt these two groups because the former might need gasoline and diesel for tractors and fishing boats while the latter is operating under a razor-thin profit margin as fuel prices stay high and more and more people buy their cars. However, the latest fuel shortages in Southern China have revived the debate again, and a fuel tax seems to be not far from reality.

\subsubsection{China's responses to lack of reliability of its oil imports}

As discussed earlier a country's reliability of oil imports has two dimensions—source reliability and transport reliability. To enhance both sides of the reliability of its oil imports, China relies primarily on the power at the disposal of the state and its national oil companies (NOCs). Perceiving oil as a scarce and strategic commodity and the oil market as manipulated by major international monopoly capital, the Chinese government believes that special relationships with energy producers will guarantee the country reliable access to oil imports. Guided by that philosophy, the Chinese government has been actively conducting "energy diplomacy” by establishing a series of special relationships with oil exporters or

\footnotetext{
${ }^{127}$ American regulators call for each automaker to produce a fleet of passenger cars within an average fuel economy of 27.5 miles a gallon under a combination of city and highway driving with no traffic. Light trucks, including mini vans, S.U.V.'s and pickups, are allowed an average of 20.7 miles a gallon without traffic.

128 “Ranliao xianzhi biaozhun luodi, yu gai chengshi youxi guize”("Fuel efficiency standards in place, rule of games will be changed in atuo markets”), Xinhua News, Online Edition, available at http://news.xinhuanet.com/auto/200410/24/content_2132253.htm, October 24 2004, accessed September 1, 2005.
} 
exporting regions. This energy diplomacy can take the form of building "strategic partnerships.” For example, as shown by Table 12, the country has established strategic partnerships with a group of major oil exporters including Saudi Arabia, Russia, Kazakhstan, Venezuela, Indonesia, Nigeria, etc. It can also take the form of negotiating free trade agreements (FTAs). For example, China has already signed a FTA with the Association of Southeast Asian (ASEAN) countries, and it is negotiating FTAs with Australia, Myanmar, and the Gulf-Cooperation Countries (GCC), which includes several major oil producing countries in the Persian Gulf-United Arab Emirates, Bahrain, Kuwait, Oman, Qatar and Saudi Arabia. Moreover, it can also take the form of providing economic assistance, such as debt relief. For example, between 2000 and 2002, China granted debt relief worth 1.26 billion US dollars (10.5 billion yuan) to 32 African countries; in 2003, the country cancelled debts of African countries to China worth 750 million US dollars. ${ }^{129}$ Furthermore, it can also take the form of assisting with infrastructure construction in energy rich countries, such as building railways in Nigeria, port facilities in Gabon, metro systems in Iran, and providing electricity to slums in Angola. Thanks to the country's energy diplomacy initiatives, its NOCs have been making strides in securing oil assets and large energy deals to quench the country's thirst.

Table 12. China's energy strategic partnerships

\begin{tabular}{|l|l|r|}
\hline Russia & Strategic partnership of cooperation oriented toward the 21st century & 1996 \\
\hline Saudi Arabia & Strategic oil partnership & 1999 \\
\hline ASEAN & $\begin{array}{l}\text { Strategic partnership of common progress between the two countries in } \\
\text { the new century }\end{array}$ & 2001 \\
\hline Argentina & Strategic Partnership for Peace and Prosperity & 2003 \\
\hline Brazil & Strategic partnership & Nov. 1, 2004 \\
\hline Nigeria & Strategic partnership & Nov. 1, 2004 \\
\hline Indonesia & Strategic partnership & April 1, 2005 \\
\hline Kazakhstan & Strategic energy partnership 1,2005 \\
\hline Canada & Strategic partnership & July 8, 2005 \\
\hline
\end{tabular}

Ever since the late 1990s China has been encouraging domestic companies to "go out" and invest abroad. After the $15^{\text {th }}$ Party Congress, the strategy figured more prominently and became an official strategy in 2000. As part of the go out strategy, China's four NOCs-CNPC, CNOOC, Sinopec, and Sinochemhave been investing overseas aggressively, partly to push forward their dream to become an international oil company (IOC) and partly to secure the country's oil imports at the very source. Though still minimal, their efforts have paid off handsomely.

${ }^{129}$ Data on China's debt relief to Africa between 2000 and 2002 is obtained from the official website of the Ministry of Commerce, PRC, available at http://caitec.mofcom.gov.cn/aarticle/a/200408/20040800263641.html, August 14, 2004, accessed September 10, 2005; For China’s cancellation of African debts in 2003, see “China Grants 750Million-US-Dollar-Debt Relief to Africa,” People’s Daily, Online Edition, available at http://english.people.com.cn/200309/06/eng20030906_123840.shtml, September 8, 2003, accessed September 10, 2005. 
Starting from a 1993 investment in 1800 abandoned oil wells of the Talara oil field in Peru that only led to 80 tons of additional oil output after millions of dollars, CNPC, China's largest NOC, has been on a fast learning curve. By the end of 2004, the company owns and operates 20 oil and gas exploration and production (E\&P) projects in 12 countries and has invested in more than 20 countries. Its overseas investment is mainly concentrated in Asia, Africa, North America, and South America. As illustrated by Table 13, in 2004 CNPC's overseas oil production topped 30 million tons and its equity oil production reached more than 16 million tons, with an increase of $20.2 \%$ and $27.5 \%$ respectively. Noticeably, its equity oil production has increased rapidly, almost doubling from 2001 to 2004.

Table 13. CNPC's overseas oil reserves and production, 2001-2204 ${ }^{130}$

\begin{tabular}{|c|c|c|c|c|}
\hline New reserves (million tons) & 30.02 & 80.08 & 405.6 & 55.87 \\
\hline Operation crude production (million tons) & 16.23 & 21.29 & 25.098 & 30.117 \\
\hline Equity crude production (million tons) & 8.31 & 10.15 & 12.884 & 16.423 \\
\hline
\end{tabular}

Similarly, Sinopec, China's second largest NOC, has also been actively pursuing the go out strategy. It has invested in more than 30 oil and gas projects in Iran, Saudi Arabia, Gabon, Kazakhstan, Yemen, and Ecuador, bringing its equity oil production to more than 200,000 tons. ${ }^{131}$ Most noticeable is the company's success in the world's top oil producers-Saudi Arabia and Iran. In March 2004, Sinopec became one of the first foreign businesses in three decades to be awarded a natural gas contract in Saudi Arabia, under which Sinopec will take over 40,000 square kilometers in the Rub Alkhali Basin. In the same year, Sinopec landed a gigantic 70 billion dollar deal with Iran, under which the company would get a 51\% stake over the Yadavaran oil field and in return Sinopec would agree to buy 250 million tons of LNG from Iran over 30 years.

Though primarily focusing on natural gas operations in Asia, CNOOC, China's third largest NOC, has also secured large overseas oil assets for the country. Through two separate purchases in 1993 and 1995, CNOOC bought from ARCO a 39.51\% stake in the Malacca oil field offshore of Indonesia. In addition, on January 18, 2002, CNOOC purchased from Spanish Repsol-YPF five oil assets in Indonesia for \$585 million US dollars. This purchase afforded CNOOC an equity oil production of 40 million barrels per year, making it the largest gas producer in Indonesia. ${ }^{132}$ These two contracts are only some examples of CNOOC's 167 oil contracts with 72 oil companies in 19 countries and regions it had concluded by the end of May 12005 . $^{133}$

Although traditionally a pure oil and chemical trading firm, Sinochem started to invest in overseas upstream businesses, and since 2003 it has made quite some progress. In early 2003, Sinochem made its first overseas acquisition by taking over Atlantis, a unit of the Norwegian oil field service group Petroleum Geo-Services, which has gas assets in the United Arab Emirates, and oil assets in Tunisia and

\footnotetext{
${ }^{130}$ Data obtained from CNPC’s website, available at http://www.cnpc.com.cn/zyyw/hwyw_hwyqyw.htm, accessed September 2, 2005.

${ }^{131}$ Data obtained from Sinopec website, available at http://www.sinopecgroup.com/business/30.shtml, accessed September 2, 2005.

${ }^{132}$ Data obtained from CNOOC's website, available at http://www.cnooc.com.cn/defaulten.asp, accessed September 2, 2005.

133 Ibid.
} 
Oman, for nearly \$105 million. Late that year, Sinochem paid \$100 million for a stake in an Ecuadorian oil field, thereby raising its annual production from equity oil to 31.4 million barrels. ${ }^{134}$

Thanks to the aggressive implementation of the go out strategy, currently China’s NOCs have invested \$7 billion in 65 oil and gas projects in more than 30 countries. In 2004, imports from equity oil reached 17.5 million tons, accounting for $14 \%$ of China's total imports in terms of quantity. ${ }^{135}$ The objective is to increase the share of equity oil imports to 70 million tons by 2020, accounting for one quarter of China's total imports. One more contribution to China's oil security from the NOC's active overseas investment is that China has rapidly diversified the sources of its oil imports, doubling from 15 suppliers in the early 1990s to more than 30 suppliers at present.

Other than improving source reliability, securing transport reliability of China's oil imports tops the central leadership's agenda. Although 93\% of the country's oil imports are shipped by sea and 80\% of its oil imports pass through the Malacca Strait, China perceives it has no control over either of them. Therefore, the country has no choice but to maintain good relationships with the countries that patrol the SLOCs running from the Persian Gulf to Malacca Strait and countries that sit on the Malacca Strait. Specifically, China has focused on maintaining good relationships with both the United States and ASEAN countries to guarantee the passage of its oil imports. China is worried about the possibility that United States would cut off China's oil imports through the Malacca Strait should the two countries enter into a conflict over Taiwan. It was reported that at a central economic conference in November 2003, Chinese President Hu Jintao urged that strategic importance be attached to resolving China's "Malacca dilemma."136

In order to reduce the reliance on the Malacca Strait, China has been constructing several oil pipelines. China started to conduct a feasibility study to build an oil pipeline from Angarsk in Russia's East Siberia to Daqing in Northeast China in the late 1990s and reached an agreement with Russia in 2001 (Fig. 18). But lured by Japan's offer of providing $\$ 7.5$ billion to finance building a longer pipeline from Angarsk to Nakhodka, the Russian government pit Chinese against Japanese to maximize benefits by exporting more energy to multiple buyers. Environmental concerns about potential damages to Lake Baikal done by the pipelines running from Angarsk also complicated the choice of the oil pipeline, creating ground for an even longer pipeline running from Taishet to Nakhodka bypassing the lake. Irritated by the uncertainties involved in the Russia-China pipeline, the Chinese government decided to put the once-sidelined KazakChina pipeline on the front burner. As a result, construction of the 1300-kilometer long pipeline from Atasu in Kazakhstan to Alashankou in Xinjiang was launched on September 28, 2004, and is expected to be completed by December 12, 2005. On completion, the Atasu-Alashankou pipeline will deliver 10 million tons of oil per year from Kazakhstan to China. Alarmed by the possibility of losing its oil market to Kazakhstan and frustrated by Japan's insistence that the pipeline issue be linked to the disputed Kurile Islands, Russian President Putin declared during the G-8 meeting this July (2005) that Russia will build the China section of the Taishet-Nakhodka pipeline first, thus winding up the long saga between China

${ }^{134}$ Official Sinochem Website, available at http://www.sinochem.com/cn/annual/petroleum.asp, accessed September 9, 2005.

135“'Zhouguo youqi qingxin haoyang shiyou, zhonghaiyou yutun younike” (China’s oil companies turn to offshore oil, and CNOOC wants to take over Unocal), Zhongguo jingji zhoukan (China Economic Weekly), available at http://www.zgjjzk.cn/more.asp?TN_NID=2005-07-03-1012, July 3 2005, accessed September 2, 2005.

136 "Zhongguo nengyuan anquan de qianzai weixie: guodu yilai maliujia haixia," (The Potential Threat to China's Energy Security: Overdependence on the Malacca Strait), China Internet Information Center, available at http://www.chinadaily.com.cn/gb/doc/2004-06/15/content_339458.htm, June 15 2004, accessed September 3, 2005. 
and Japan. According to a recent announcement, the pipeline will run from Taishet to Skovorodino, which is only 60 kilometers east of China's Manzhouli railway station. It will be built to ship 20 million tons of oil to China's Daqing per year and an additional 10 million tons will be sent on rail to Nakhodka. Construction of the first phase of the pipeline is expected to be completed by 2008. On completion, the Kazakh and Russian pipelines will provide 30 million tons of oil to China annually, thus reducing the country's dependence on the Middle East by at least $20 \%$.

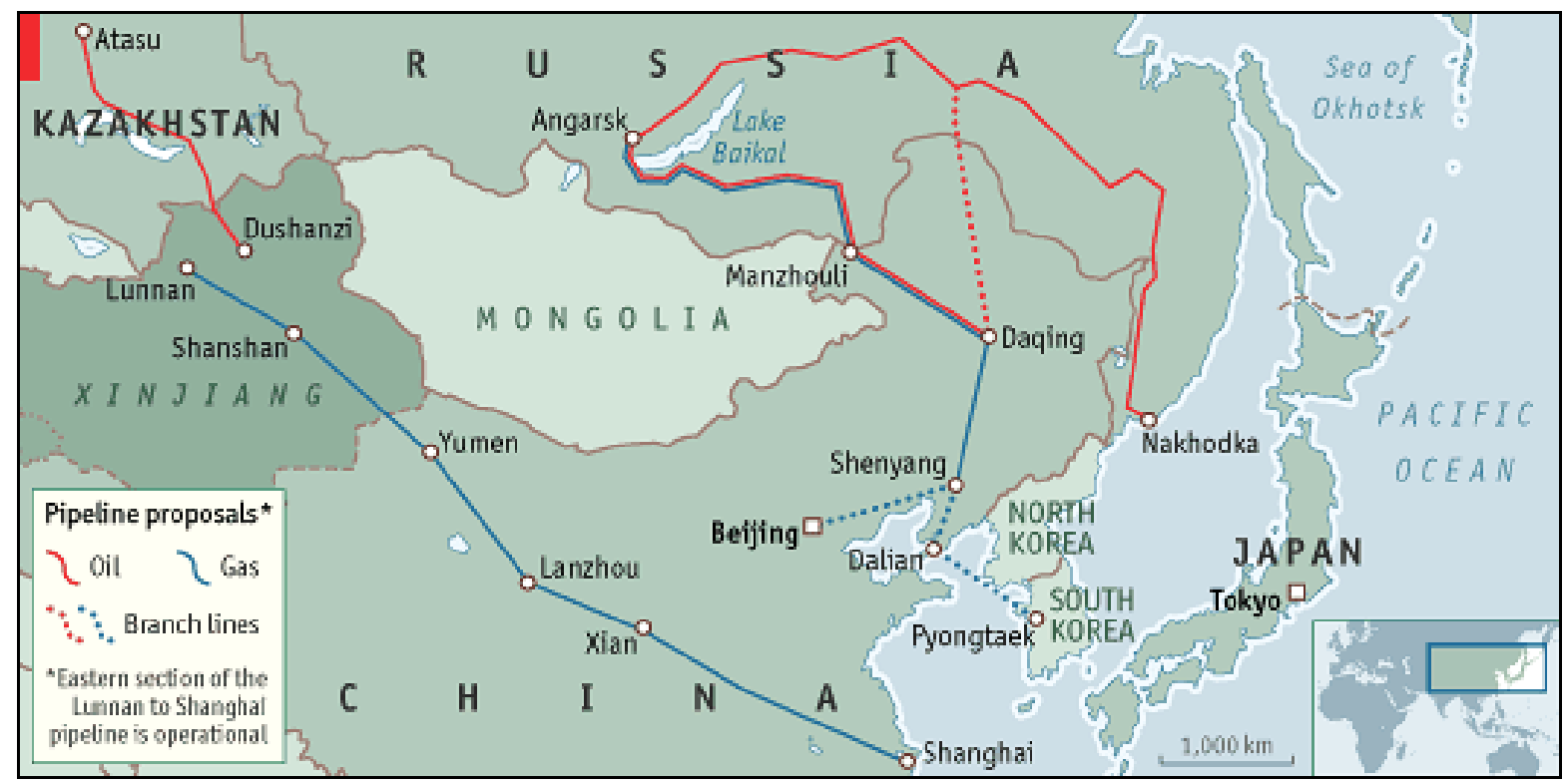

Source: Economists.com

Figure 18. Oil pipelines serving China

Other than the two already determined oil pipelines, China is also considering building new oil pipelines to diminish its reliance on the Malacca Strait. According to an official report, the NDRC commissioned a study looking into three more options: building an underwater oil pipeline that runs below the line that the Kra Canal would travel, constructing an inter-Asian rail system that can carry oil to China, or opening up the Kra Canal from Thailand across the Indian Ocean to China. ${ }^{137}$ The first two proposals were killed quickly because of their limited shipping capacity whereas the third one received a lot of attention. Opening up the Kra Canal would shorten the distance between the Pacific Ocean and the Indian Ocean by at least 700 miles and save crude tankers 2 to 5 days, reducing their cost by 300,000 US dollars.

However, a couple of factors work against the choice. First, it would take too long and cost too much. According to an estimate, the project would take 10 to 15 years and cost at least 20 billion US dollars. Second, it would complicate China's relationship with the three countries that sit on the Malacca Strait, Indonesia, Malaysia, and Singapore. As the completion of the canal would lessen the traffic of the Malacca Strait, the three littoral states' business interests would be negatively affected, particularly Singapore's. As such, China is concerned that its relationship with the three countries would be

\footnotetext{
137 “Zhongguo nengyuan anquan de qianzai weixie: guodu yilai maliujia haixia,” (The Potential Threat to China’s Energy Security: Overdependence on the Malacca Strait), China Internet Information Center, available at http://www.chinadaily.com.cn/gb/doc/2004-06/15/content_339458.htm, June 15 2004, accessed September 3, 2005.
} 
compromised if it supports the Kra Canal. ${ }^{138}$ Third, the Thai government does not have enough money to conduct the feasibility study or to launch the construction by itself. Finally, the proposed Kra Canal borders the five Muslim-majority provinces in Southern Thailand, which have seen increasing conflicts recently. As a consequence, the Kra Canal proposal appears pretty much dead on China's political agenda.

Meanwhile, the Yunnan University's Institute of Southeast Asia proposed another option: building a Myanmar-China pipeline. According to the proposal, the proposed pipeline will run from Kunming, Yunnan's capital, to the Indian Ocean port of Sittwe (Akyab), a straight-line distance of about 1,250 kilometers. Compared with the current oil route via the Malacca Strait, this means a savings of about 2,000 kilometers. It would cost only about 2 billion US dollars, much cheaper than the Kra Canal project. Although some scholars question the merit of the pipeline, as China's east coast instead of Yunnan is the country's economic center and consumes the majority of imported oil, the proposal has aroused enormous interest. According to People's Daily, the proposal won over the endorsement of Chengqing Municipality and Sinopec, China's largest refinery company; as a result, they have both submitted a report to the State council to convince the central government to put the proposed project into the country's $11^{\text {th }}$ Five Year Plan. ${ }^{139}$

In addition to pipelines, the Chinese government also ramped up efforts to expand the domestic crude tanker fleet to ship its oil imports and the navy fleet to protect its oil imports. According to an official report, in an attempt to improve the country's oil transport security the Chinese government will invest in a $\$ 10$ billion program to allow its domestic crude tanker fleet to ship 50 million tons of its crude imports, or half of the country's total imports. ${ }^{140}$ As imports grow, shipment by the domestic fleet will increase to 75 million tons by 2010 and to 130 million tons by 2020. Meanwhile, as part of China's military modernization drive, it is speeding up its navy upgrading as well. Although it still does not have the projected capacity yet, the long-term goal dictates that the military modernization will eventually allow China to protect the SLOCs through which its oil imports go through, by the Chinese navy.

\subsubsection{China's responses to the affordability its oil imports}

While the volatility of oil prices and the ever increasing volume of oil imports brought home to the Chinese leadership how the affordability of its oil imports can jeopardize the country's oil security, the war in Iraq precipitated an urgency to deal with the affordability issue. To beef up the country's ability to withstand the test of oil market fluctuations, the central leadership established the State Strategic Petroleum Reserves Office in May 2003 under the NDRC and charged it with the mission to set up China's SPRs system. Four locations-Zhenhai (Zhejiang Province), Daishan (Zhejiang Province), Huangdao (Shandong Province) and Dalian (Liaoning Province) — were selected to build SPRs with a total capacity of 50 million tons of oil. The first-stage of the program is now in full swing, and is expected to be completed before 2008. Upon completion, the four bases will altogether form a government strategic reserve capacity equivalent to the country's crude imports in 10 days. Adding the country's 21

\footnotetext{
138 Zhongguo nengyuan de qianzai weixie, guodu yilai maliujia haixia, (“The Potential Threat to China’s Energy Security-Overdependence on The Malacca Strait”), China Information Network, available at http://www.china.org.cn/chinese/junshi/586759.htm, June 15, 2004 accessed September 10, 2005.

139 "Chongqing lizheng zhongmian shiyou guandao ruyu” (Chongqing Fights for the Passage of the China-Burma Oil Pipeline), People’s Daily Online, available at http://finance.people.com.cn/GB/1038/3277783.html, accessed July 192005.

140 “China to Increase Oil-Supply Security,” People’s Daily, Online Edition, available at http://english.people.com.cn/200401/09/print20040109_132208.html, January 9 2004, accessed July 17, 2005.
} 
days of commercial oil reserves primarily held in the hands of its three NOCs, by 2008 China's overall oil reserve capacity will exceed 30 days of imports. Moreover, this is only the first step toward a long-term goal set by the government to achieve a SPR capacity of 90 days by 2015 .

Other than building SPRs, the government also resorted to a market mechanism to strengthen its affordability of oil imports, and to large extent its market power in determining oil prices in China. China imported 123 million tons of oil; 86\% of its imports are priced on the spot markets. However, without an oil futures market of its own it can barely hedge against market fluctuations, let alone use the market power derived from its importance as the second largest oil consumer in the world. Furthermore, China is Asia's largest consumer of fuel oil accounting for $8 \%$ of world's fuel oil use each year. It buys half of its total consumption from abroad, but the prices of its fuel oil products are largely determined at the Singapore market. As a result, China's oil importers often fall victims of volatile fluctuations in the Singapore market or elsewhere. Under the pressure from oil companies at home and in an attempt to hedge against market fluctuation and exercise its market power in determining oil prices, the central government decided to reopen an oil futures market, which was closed in 1995 after only two years of operation. Unlike last time when crude oil, gasoline, diesel and fuel oil were all allowed to trade on Beijing and Shanghai Futures Exchange markets, this time only fuel oil is allowed to trade on Shanghai Futures Exchange market. This limitation indicates the cautious approach the government takes and also reflects the reality that fuel oil is the most liberalized oil product in China with the least control by the government. Nevertheless, the debut of the fuel oil futures market will pave the way for other oil products such as gasoline, diesel and crude oil. The long term goal of the government is to build an oil futures market integrated with the rest of the world that will help the world's second largest oil consumer and Asia's largest fuel oil consumer not only hedge against oil prices but also exercise its impact on market price determination, thereby enhancing its oil insecurity.

\subsection{China's responses to its institutional insecurity}

While the government addresses the cyclical and structural aspect of its energy insecurity, it has also started to augment its institutional capacity to tackle the country's energy security in a systematic and comprehensive approach. As discussed earlier, China's energy policy making system is stymied by too many "cooks," lack of coordination, and vague division of labor. As a consequence, it is often unclear who makes the energy policy in China or who implements the energy policy after it is made. Another corollary of China's energy policy making structure is that its energy policy is often made in an ad-hoc fashion without a long-term strategy and often delineated and implemented along sector lines.

China’s energy experts have long called for improvements to its energy policy making system and institution of an overall policy making body to be in charge of energy policy. However, the fight among different interest groups from government agencies and the energy sector made the policy reforming process a treadmill. Once again the heightened sense of oil insecurity generated by the war in Iraq, as explained earlier, catalyzed the acceleration of energy policy restructuring process in China. In May 2005, the State Council issued No. 14 Document, according to which a State Energy Leading Small Group (LSG) was established, headed by Premier Wen Jiabao and assisted by two Vice Premiers-Huang Ju and Zeng Peiyan. In addition, the group members include 13 top leaders from the country's major ministries and administrations, including the Minister of NDRC Ma Kai, Minister of Commerce Bo Xilai, Minister of Foreign Affairs Li Zhaoxin, and Minister of State Commission of Science, Technology, and Industry for National Defense Zhang Yunchuan. This is the first time since 1993, when Ministry of Energy was dissolved, that a central body has been inaugurated to be in charge of China's overall energy policy. 
The leading group, however, does not meet on a routine basis. To support its routine work, the central government set up a 24-member State Energy Office on June 2, shortly after the creation of the State Energy LSG. The office was headed by Ma Kai, head of NDRC, aided by Ma Fucai, the former ministerial-level general manager of CNP and Xu Dianmin, director of Energy Bureau within NDRC. The State Energy Office will be an acting body of the State Energy LSG, backing its work and carrying out its decisions. Figure 19 summarizes the structure of the State Energy LSG and other agencies in China.

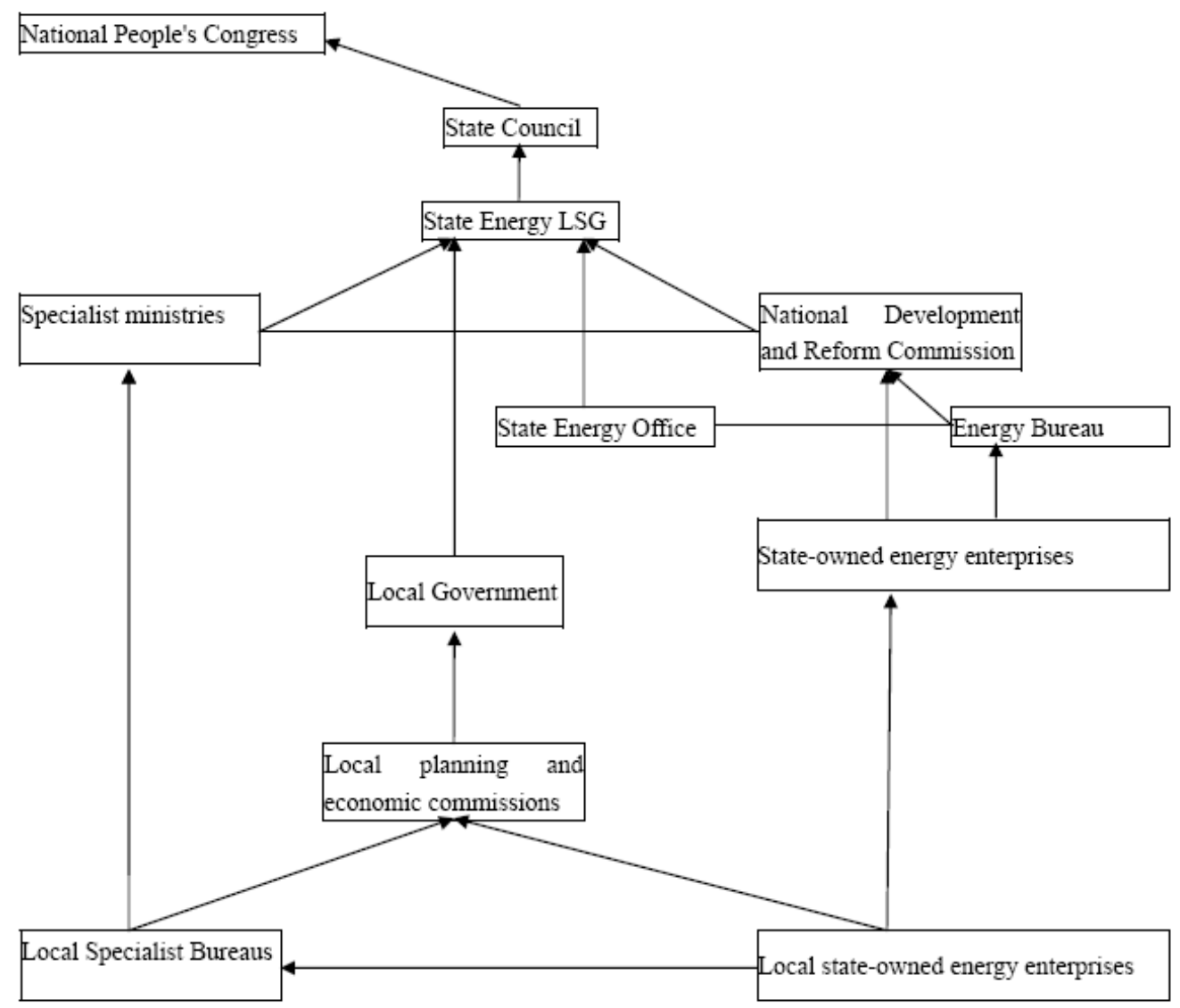

Figure 19. Summary of the regulatory structure of state energy enterprises in China, 2003 to the present ${ }^{141}$

In addition to restructuring the country's energy policy making system, the central government has also embarked on a journey to reform its energy industry. The demarcation between the country's NOCs used to be clear cut, with CNPC focusing onshore and CNOOC focusing on offshore exploration and production (E\&P), Sinopec on the refinery and marketing sector, and Sinochem on the international trading sector. In an effort to break up the sectoral monopoly enjoyed by the NOCs and to boost their ability to secure the country's energy security, just as with the telecom industry, the central government started to introduce competition among the four giants in China's oil sector. As a consequence, the lines

${ }^{141}$ Modified after Philip Andrews-Speed, “Energy Policy and Regulation in the People’s Republic of China,” (The Hague/London/New York: Kluwer Law International, 2004). 
between the four NOCs in China are increasingly blurred. After Sinochem, the traditional oil trader in China, received authority to invest in overseas upstream acquisitions in 2001, it has expanded its investment in overseas E\&P. In addition, in November 2004 the company announced its bid for Inchon Oil Refinery Corporation, the South Korean bankrupt oil refinery, marking its first step toward refinery business. Similarly, CNPC, the traditional onshore giant, received authorization in July 2004 from the Ministry of Land and Natural Resources to conduct E\&P in the South China Sea in addition to its E\&P business in East China Sea. The downstream giant Sinopec also acquired the right to conduct E\&P business in South China Sea in 2000 and is marching toward East China Sea E\&P business. Furthermore, both CNPC and Sinopec are starting to make their forays into the LNG business, which has been dominated by CNOOC. Confronted with the competition from its siblings, CNOOC, after years of fight, finally managed to obtain the right to import oil in May 2003, thereby ending the irony that CNOOC had to sell its equity oil on the international market because oil trading rights were exclusive prerogatives of CNPC, Sinopec and Sinochem. Moreover, CNOOC announced in July 2004 that it will invest more than 17 billion yuan (more than 2 billion US dollars) to build China's largest refinery in Southern Guangdong Province. To further integrate its businesses, CNOOC also signed a deal with the Inner Mongolia Autonomous Regional government to take over the Tianye Chemical Group and expressed interest in conducting E\&P businesses in the CNPC-controlled Changqing Oilfield located in the Ordos Basin, indicating its inroads into the downstream business as well.

In addition to injecting competition among the four NOCs, China also started to open its domestic energy market partly to honor its WTO obligations, but partly to increase the number of players in the energy market, thus allowing a larger number of oil companies to secure oil for the country. The opening up took place in three areas. First, the central government is increasingly relaxing import quotas for oil and oil products imposed on non-state owned oil companies. China granted its non-state oil companies import quotas to import oil and oil products for the first time in 2002, allowing them to import 8.28 million tons of oil and 4.6 million tons of oil products. As shown by Figure 20, ever since 2002 the import quotas allocated to non-state owned oil companies have been growing at $15 \%$ for both crude oil and oil products.

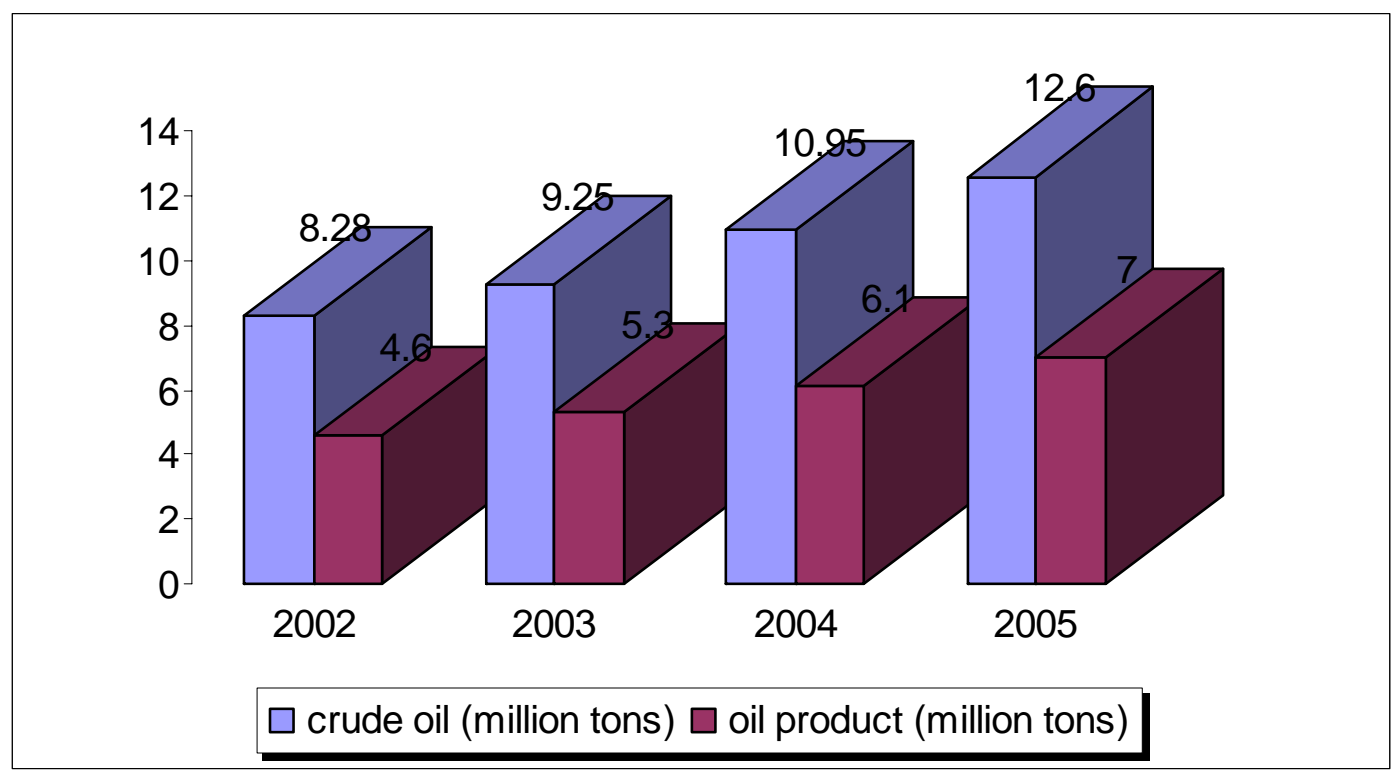

Figure 20. Imports of oil and oil product by non-state owned oil companies since 2002 in China ${ }^{142}$

142 Source: Based on data published by China’s Ministry of Commerce. 
Second, as part of its WTO commitments the central government opened the retail market of oil products, allowing foreign oil companies to open gas stations in China. As a result of that policy, international oil companies have flocked into China to set up gas stations, with the Royal Dutch/Shell group in the process of erecting 500 gas stations, BP 1000, and Exxon-Mobil 1100 in Southern China, while French Total SA is building 200 gas stations in Northern China with either Sinopec or CNPC.

Finally, the central government also decided to open the upstream business in the oil and gas sector to private investment. On February 24, 2005, the central government issued a policy document called "Opinions of the State Council on Encouraging, Supporting and Guiding the Development of Private and Other Non-Public Economic Sectors,” the Central Government's first document on promoting the development of private enterprises since the founding of the People's Republic of China in 1949. This policy document marks the first step toward rectifying the awkward situation in China where domestic capital was not allowed to be invested in areas where foreign capital was allowed. More important, it granted private capital the right to conduct oil E\&P and mining. To echo this new round of opening up in the energy sector, the Great Wall United Petroleum Company (GUPC), China's first independent oil giant, was formed on June 29 this year, representing more than 30 domestic privately-owned oil firms.

\subsection{An assessment of China's responses to energy insecurity}

Responding to the cyclical, structural and institutional dimensions of its energy insecurity, the Chinese government has adopted multi-pronged strategies focusing on both the supply side and the demand side of the energy equation. To be fair, the Chinese government deserves credit for its effort to bridge power shortages, reduce pollution, enhance the availability, reliability, and affordability of its oil imports, and improve its institutional capacity to make sound energy policies. Nonetheless, China still has a long way to go before it achieves energy security.

First, while the cyclical energy insecurity (power shortages) will be eased in 2006, China will be faced with power oversupply issues again starting in 2007 or 2008. Though not as painful as power shortages, the power glut also means a waste of economic resources, particularly when the power grid in China does not allow extra electricity to be exported on a large scale. Moreover, the power glut will again slow down investment in the power sector, at least at the local government level, thereby planting seeds for another round of cyclical power shortages. In that sense, the power glut creates as significant a challenge to the Chinese government as power shortages.

Second, while the Chinese government has invested millions of dollars to reduce pollution caused by too much coal consumption and established a green GDP system to calculate environmental externality in its GDP, coal will dominate China's total energy consumption in the foreseeable future. Currently, two thirds of the country's total energy comes from coal, with $80 \%$ of its electricity generated by coal and $75 \%$ of its power plants operating on coal. Moreover, $90 \%$ of the recently added power plants in response to power shortages are coal-fired. By 2020, coal will still be contributing about $60 \%$ of China's total energy consumption. However, only $21 \%$ of coal produced by China's large scale coal enterprises is washed. ${ }^{143}$

\footnotetext{
${ }^{143}$ China produced 1516.9 million tons of coal, but only 311.3 million tons were washed, accounting for only $21 \%$ of the total production. Source: 2004 Main Economic Indicators of Large Scale Coal Companies, Industry Statistics, published by China Coal Industry Network, available at http://www.chinacoal.gov.cn/tongjifenxi/200505/09/content_96055.htm, May 9 2005, accessed September 11, 2005.
} 
Therefore, environmental pollution caused by dirty coal consumption will still constitute a great threat to the country's environment security.

Third, China's multi-pronged strategies have not dramatically improved the country's oil security. In terms of the availability of oil, despite all efforts launched by its NOCs onshore and offshore, at home domestic production has been growing disappointingly at $1.67 \%$ per year on average since 1993 , whereas consumption has grown at 5.82\% per year. Similarly, although China has doubled the number of its oil suppliers from 15 to 30 countries, its top 10 suppliers provide more than $80 \%$ of its oil imports. Its energy diplomacy and go out strategy secured some assets abroad, but they are minimal by domestic and global standards. Equity oil only accounted for $14 \%$ of China's total oil imports and $6 \%$ of the country's total oil consumption in 2004. Even after prolonged global investment, by 2020 the import of equity oil will quadruple to 70 million tons but the country will only control less than $2 \%$ of global oil production. Moreover, as the setbacks China's NOCs suffered in acquiring assets in the Caspian Sea area and in acquiring Unocal proved, the expansion of China's NOCs and its global acquisitions are by no means going to see smooth sailing. More important, even if all goes well and Chinese NOCs can control about $2 \%$ of global oil output by 2020, China still lacks the capability to protect the SLOCs that range from the Persian Gulf to the Malacca Strait. When the Myanmar-China pipeline is constructed, China's reliance on the Malacca Strait will be reduced somewhat. Yet it still relies on the SLOCs which it does not yet have a powerful navy to protect. Similarly, the country's effort to build SPRs and oil product futures market are commendable, but those measures are still at their infancy. The current SPRs system is only designed at 30-day supply and will not be completed until 2008. Compared with the International Energy Agency requirement for 90 days of supply, China still has a long way to go. Similarly, although as a positive step forward, the current oil futures market only includes oil product, it remains to be seen when the Chinese government will allow crude oil to be traded on the futures market. It is likely that it will take years if not decades for China's futures market to have a decisive role in determining the world's oil prices. All in all, the country's efforts to search for oil security still face many obstacles.

Finally, at the institutional level, although the central government recently restructured both the energy policy making system and the energy market structure, neither move has tackled the real hurdles in place. To start with, the recently established State Energy LSG, although headed by Premier Wen Jiaobao and Vice Premier Zeng Peiyan, is neither a permanent institution nor a policy making body. For instance, the State Energy LSG includes 13 ministers from different government agencies, but it does not have staff. Nor does it have any official office or meet on a daily basis. In terms of authority, the LSG is responsible for research into major important issues involving the development blueprint, energy exploration and conservation, security and emergency systems as well as international cooperation within the energy sector. It will offer proposals for the State Council to make policies for sustainably driving the industry. It will, if necessary, invite other official leaders and industry experts from China's major energy companies and research institutes to join in the research work. ${ }^{144}$ Clearly, its mandate makes it more like a high-level research group or advisory council rather than a decision making body. Aware of the State Energy LSG's inability to meet on a routine basis, the central government set up the State Energy Office headed by Ma Kai to be its acting agency. However, the central government did not clarify the division of labor between the existing Energy Bureau under NDRC and the newly established State Energy Office. Therefore, neither the State Energy LSG nor the State Energy Office will help clarify who in China makes and

\footnotetext{
144 “Premier Wen Heads New Energy Group,” People’s Daily, Online Version, available at http://english.people.com.cn/200505/27/print20050527_187115.html, May 25, 2005, accessed August 31, 2005.
} 
implements energy policy. Furthermore, even if the State Energy Office is fully functional, it will only have 24 people. Adding the 15 people on the State Energy LSG, 24 people at the State Energy Office, and 30 people from Energy Bureau, only 69 people at the national level will be working to solve the energy challenges for the 1.3 billion plus people in China, which almost guarantees failure. More importantly, establishing a State Energy LSG instead of a Ministry of Energy indicates the fierce debate and lack of consensus among the government as to how to reform its energy policy making system. The State Energy LSG came into being as a result of a compromise among different agencies and interest groups.

Unfortunately, as long as the debate is not resolved, China will not have an energy policy making system capable enough to make and implement sound energy polices.

The lack of consensus in the central government directly affects its efforts to restructure the energy industry. Although the central government allows non-state-owned oil companies to engage in crude oil and oil products trade, they only get to import less than $10 \%$ of the country's crude imports and $14 \%$ of its oil products imports. As a result of the import quota, some non-state-owned oil companies are squeezed brutally by the country's four NOCs in the retail markets. Since most non-state oil companies in the retail market do not have their own crude oil or oil products, they have to rely on the four NOCs, thus strengthening the NOCs' monopoly over the oil markets. Moreover, oil prices in the country are still determined by the state rather than by the market. Together with this monopoly, price controls generate not only a huge amount of inefficiency but also perverse incentives that threaten the country's oil security. A typical case in point comes from the recent fuel shortages in Guangdong where non-state gasoline stations rely on NOCs for fuel supplies while the NOCs choose to export their refinery products abroad to take advantage of higher prices elsewhere. This anomaly occurs because gasoline prices in China are much lower than those in international markets. As a result, the NOCs have to pay higher prices for oil they import from international markets but sell their refinery products at lower prices in domestic markets. Hence, they incur losses, up to $\$ 125$ by some estimates, ${ }^{145}$ for every ton of gasoline they sell in China. This anomalous pattern in China's oil import and export is further echoed by the fact that despite the country's growing dependence on foreign oil, its oil exports leaped by $29.2 \%$ while its oil product jumped by $45.5 \%$. ${ }^{146}$ Consequently, accompanying China's growing exports of crude and oil products is its fuel shortages that brought thousands of cars to a standstill on the street and forced many others to wait in long lines to access rationed gasoline.

In short, China's energy insecurity occurs when the country, on its way to industrialization and urbanization, finds itself unable to meet the requirements for the availability, reliability, and affordability of its energy supply, together with the environmental compatibility of its energy consumption, driven by its galloping economy. Therefore, China's energy insecurity is both multi-dimensional and long term.

Enhancing the country's energy security requires a systematic approach rather than a sectoral approach as taken so far by the Chinese government in response to its cyclical, structural, and institutional dimensions of energy insecurity. It also requires some conceptual changes as to how the central government views the role of the market to increase its energy security. For either of the two to happen, the precondition is for China to establish an energy policy making system able to make and implement sound energy policies.

\footnotetext{
${ }^{145}$ Peter S. Goodman, “Oil Exports Leave China Grappling Fuel at Home,” Washington Post, September 28, 2005, D06.

${ }^{146}$ Data obtained from Customs General Administration People’s Republic of China, cited by Ministry of Commerce, available at http://gcs.mofcom.gov.cn/aarticle/Nocategory/200509/20050900341548.html, accessed October 10, 2005.
} 
Until that happens, the country will be still muddling through with little coordination or direction to solve the country's energy insecurity.

\subsection{Why is the United States concerned about China's search for energy security?}

Why are some in the United States concerned about China's search for energy security? The strategies China has taken to enhance its energy security have presented the United States with both opportunities and challenges. Opportunities come from two aspects. First, China's campaign to increase environment security by reducing pollution provides Americans firms with opportunities to sell their advanced technology and equipment, thus improving the trade balance and creating more jobs at home. Moreover, China's success in reducing pollution, particularly air pollution will lower the possibility that the Pacific Northwest of the United States will be negatively affected by China's pollution. Second, China's efforts to increase the institutional aspect of energy security by reforming its energy industry also provide US firms with opportunities to enter into China's energy market. In fact, ExxonMobil has already entered China's oil retail market and is in the process of building 1100 gasoline stations in the Guangdong and Fujian Provinces. As China further opens up its energy market, US companies stand a good chance of expanding their business in China.

While China's search for energy security offers the United States with desirable opportunities, it also mounts some daunting challenges. First, to ease its power shortages China is stepping up efforts to expand nuclear power plants and advance its nuclear technology. This poses a series of questions to the US government. Should the US government support the desire of US firms to tap the expanding nuclear market in China by selling their advanced technology to China, which has a mixed record of nuclear proliferation? Moreover, should the US government allow advanced US nuclear technology to be transferred to China to create a new commercial competitor in the global nuclear market? While these questions are reflections of valid concerns, the fact of the matter is there is little the United States could do to stop China from expanding its nuclear power plants and becoming a competitor in the world nuclear market. Unfortunately, banning the Export-Import Bank from proceeding with a potential \$5 billion combination of loans and loan guarantees to support the Westinghouse bid for Chinese nuclear reactors will only exclude US firms from the lucrative market. On the contrary, other than Westinghouse, French, Japanese, Korean, and Russian companies have already succeeded in selling their technology to China and are all in line to sell more. Moreover, China is taking the lead in developing the "pebble bed" nuclear reactor and may soon commercialize the technology.

The real questions, therefore, are whether China will take the opportunity to expand nuclear power plants, acquire the nuclear technology, and export its nuclear technology in conformity with international nonproliferation guidelines. As China reaches out to Australia to buy more uranium, many are concerned that China will enrich the uranium to build more nuclear weapons. In addition, as China becomes an exporter of nuclear technology many are concerned that a weak export control regime in China increases the possibility that nuclear technology from China might fall in the hands of regimes or groups that the United States does not like or that do not like the United States. The recent sales of two nuclear reactors by China to Pakistan caused concerns in the United States given Pakistan's track record in nuclear proliferation and its refusal to sign the Nuclear Nonproliferation Treaty (NPT). 
Second, to increase the availability of oil, China is intensifying its E\&P activities in both the East China Sea and the South China Sea. However, border disputes in both resource rich waters have not been sorted out. In addition to disputes over a group of islands which China calls Diaoyu and Japan calls Senkaku, the two countries do not agree on the demarcation between some of the natural gas fields scattered on the floor of the East China Sea. The particular gas field that has been fueling rivalry between the two countries since May 2005 is the Chunxiao Gas Field, which lies on the Chinese side of the line but Japan is concerned that by drilling in the area China may hit veins that extend east of the line and extract resources that belong to Japan (Fig. 21). The Chinese government never recognized the median line claimed by the Japanese government. Instead, Beijing holds the continental shelf extension theory, according to which China Exclusive Economic Zones stretch to a larger extent than that designated by Japan. After two rounds of failed bilateral consultations, the Japanese government granted drilling rights to Teikoku Oil Corporation in the East China Sea gas field and CNOOC announced it will start production sometime this fall. As a result, the competition for resources, among many other things, has been contributing to the tense relationship between the two big powers in East Asia.

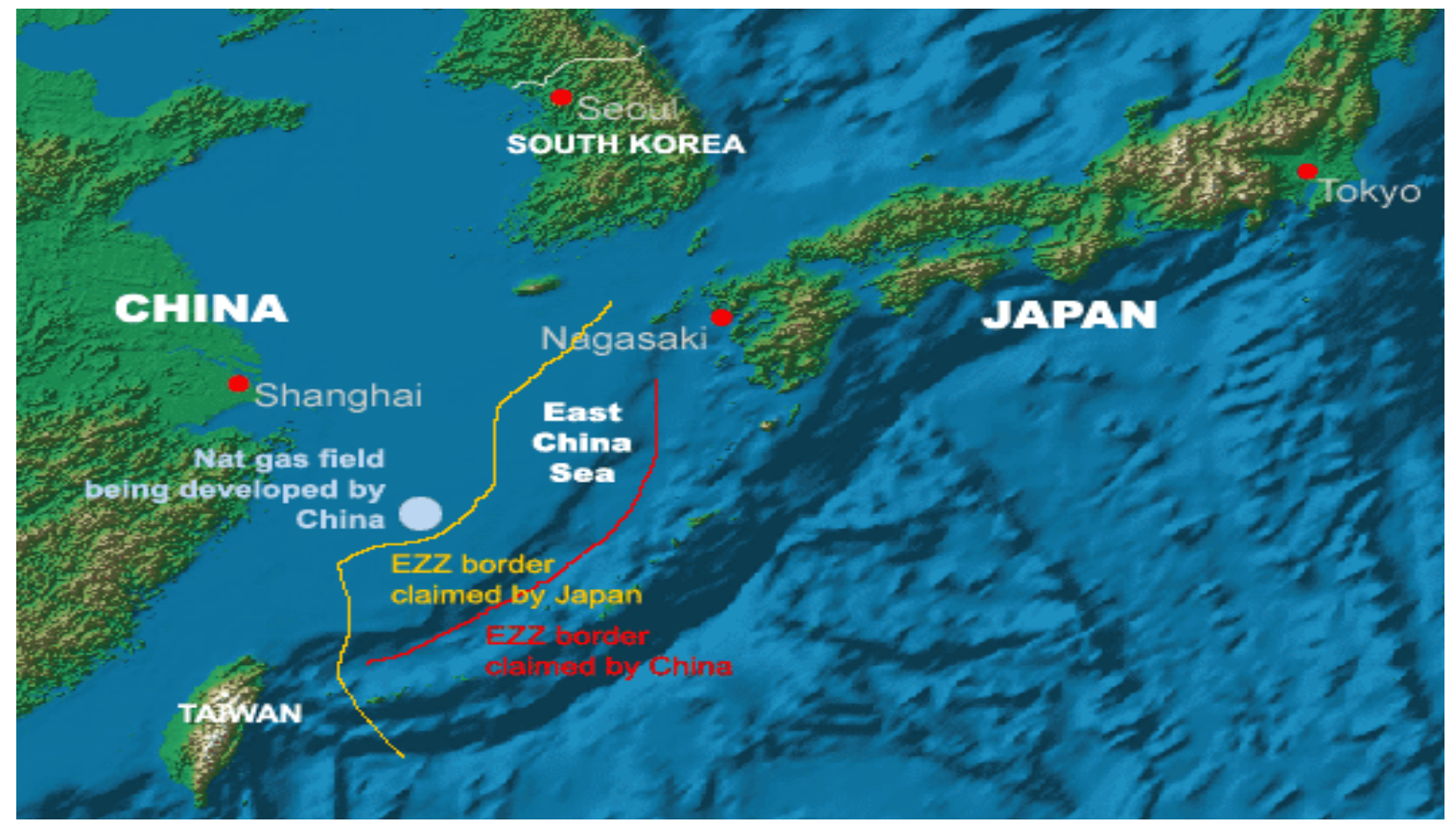

Figure 21. Gas field boundaries in the East China Sea (Source: www.rigzone.com )

For some, the scramble for resources in the East China Sea and the resultant deterioration between China and its neighbor, Japan, are precursors of what may happen when it comes to China's acceleration of E\&P activities in the South China Sea, which is claimed by Brunei, China, Indonesia, Malaysia, Philippines, Taiwan, and Vietnam. Despite the concerns, there are some good signs. Early this March, the three major claimants China, Philippines and Vietnam signed an accord, agreeing to conduct a joint marine seismic survey in certain areas in the South China Sea, where they have overlapping territorial claims. The accord, called the "Tripartite Agreement for the Joint Marine Seismic Undertaking in the Agreement Area in the South China Sea," covers 142,886 square kilometers of agreed-upon areas and will run for three years. Reassuring as it is, many argue it is too early to tell whether this joint development model will succeed 
particularly when other claimants are left out. Moreover, many suspect that once oil and gas assets are discovered dispute and rivalry will emerge again.

Third, to secure oil imports abroad China has been scavenging around every corner of the globe. What particularly worries some in the US government is that China turns to some pariah states such as Iran, blacklisted as one of the "axis of evil” and "outpost of tyranny," Myanmar, Zimbabwe, and Sudan, notorious for allowing ethnic genocide to occur under the government watch. The concern is that China's oil interests in these places will trump its concerns about the larger interests of the international community or prompt Beijing to be an obstructionist of US foreign polices. Critics point to China's reluctance to refer Iran to the United Nations Security Council or impose sanctions on Iran if it does not dissolve its nuclear program and drop its nuclear weapons ambition. Similarly, critics also point to Beijing's willingness to veto UN trade sanctions on Sudan for the government sponsored ethnic atrocities. Furthermore, they hold that China's oil trade with the repressive regime in Myanmar is undermining US sanctions and US policy to isolate the regime. More broadly, however, the US concern is that the oil trade between China and the Middle East oil producers will undercut US efforts to promote democracy in that part of the world as China's economic success provides those oil producers with a different political model.

Fourth, to ensure sufficient and reliable long-term oil supply, China's NOCs have been aggressively conducting a go out strategy, locking up long-term oil assets. Many in the oil industry and the US government as well are concerned that China is attempting to redirect the course of international oil flows. Some in the United States even went further to suggest that China is hoarding oil or trying to take oil off the international market to satisfy its consumption only, thus threatening the US national interest. The saga over CNOOC's bid for Unocal really shed light on how alarmed the US Congress became by a Chinese NOC wishing to acquire US oil assets. Similarly, many in the US government are also worried that China is "stealing” oil from US major oil suppliers, particularly Venezuela and Canada. In the case of Venezuela, it announced in late-August 2005 during a visit to China by the Venezuelan Minister of Energy and Petroleum and the president of its state oil company Petroleos de Venezuela SA (PDVSA) that it expects to export 300,000 barrels of oil per day to China by 2012 from the current level of 68,800 barrels per day. To achieve the goal, PDVSA set up an office in Beijing to expand its business in China. If the target materializes, Venezuela would become one of China's top three oil exporters and help China reduce its dependence on the Middle East oil. Similarly, during Canadian Prime Minister Paul Martin's visit to China early this year, the two countries signed a series of agreements on energy cooperation, including in the area of tar sands, and established the Canada-China Joint Working Group on Energy Cooperation. In addition, CNOOC paid 150 million Canadian dollars for a 16.69\% stake in the MEG Energy Corporation, which is a purely oil sands company based in Calgary, Canada, and owns $100 \%$ working interest in oil sand leases of 52 contiguous sections (32,900 acres) in Alberta. Meanwhile Chinese oil companies are also working with their Canadian counterparts to build a pipeline from Alberta to the coast of British Columbia to ship oil to China. China's inroads into North America and Latin America are very alarming to some because these two areas are traditionally deemed America's backyard. Moreover, for quite a while the United States has been taking oil imports from Canada, its largest oil supplier, and Venezuela, its third largest oil supplier, for granted, but now these assumptions seem to be questioned as China joins the game.

Finally, accompanying China's growing overseas energy investment is the country's growing political influence, which has been very noticeable in Southeast Asia, West Africa, Central Asia, and increasingly in the Middle East and Latin America. Many in the US government are concerned that China might use 
its growing power derived from its expanding energy investment at cross purposes to the US and weaken US influences in corresponding areas. In Southeast Asia for example, China's expanding energy investment and growing economic clout have started to affect how countries, particularly some US allies such as Australia, look at their relationships with China vis-à-vis their relationships with the United States. Specifically, Australia has made it clear it will not necessarily take the side of the US government should a confrontation erupt across the Taiwanese straits. Some US analysts took this as an indicator of the future trend and went further to suggest China is pursuing a deliberate strategy to drive the United States out of Asia. Similarly, others echo this trend in Central Asia as evidenced by the recent demand jointly made by the Shanghai Cooperation Organization, asking the United States to withdraw from its military bases in some member countries in Central Asia.

While all concerns voiced by energy analysts or US officials are understandable, not all concerns are valid or well justified. Take the concern about the possible nuclear proliferation from China's expanding nuclear programs for example; these worries are largely exaggerated. It is true that China exported two nuclear reactors to Pakistan, but that happened before China joined the Nuclear Supplier Group (NSG) in May 2003. Once a member, China is not allowed to export any nuclear technology or material unless it can guarantee the peaceful use and safe maintenance of its technology in the buyer country. In fact, according to an official report, China will stop its nuclear cooperation with Pakistan as the country attaches more importance to its international image and its trade relationship with developed countries. ${ }^{147}$ Similarly, the concern that China might take advantage of its imported uranium to increase the stock of its nuclear weapons can be easily dismissed since China itself, according the IAEA estimate, has national uranium reserves of 64,000 tons.

Concerns about nuclear proliferation are both legitimate and valid, but they are only half of the story. The risks of proliferation do not come from the central government's lack of willingness and determination to abide by international rules. Rather they come from the fact that China's export control regime is not rigorous enough to tighten control of export of nuclear technology, parts, or materials. Moreover, as the central government delegates more and more power to local governments and companies in the course of its economic opening up, the real question is whether Beijing has the ability to implement its export control policies effectively even if it builds an export control regime. In other words, the institutional capacity rather China's intentions will be a key to determine its performance in curtailing nuclear or arms proliferation as it pursues nuclear power as well as foreign oil and natural gas.

Admittedly, in its search for more oil, China has been moving closer to some pariah states such as Iran, Myanmar and Sudan and its NOCs have been locking up international oil aggressively. However, as explained earlier China's energy diplomacy has largely been driven by its perceptions that the United States has every intention to contain China's rise using oil as an instrument, its suspicions that the international oil market has been manipulated by western oil firms and western capital, and its fear that the United States might cut off its oil supply should the Taiwan contingency occur. Furthermore, the go out strategy also reflects part of the trend in China for domestically competitive companies to go global and become multinational corporations. This process happened both in Japan and Korea as they industrialized their economy. Those who claim that under the conspiracy theory, Chinese NOCs are going

\footnotetext{
147 "Zhongguo jiaru hegong jituan lichu duo, jiang zhanting yu bajisitan he hezuo” ("Benefits of China’s accession into the Nuclear Suppliers Group Abound, and China Will Stop Nuclear Cooperation with Pakistan”), Xinhua News Agency, Online Edition, available at http://news.xinhuanet.com/herald/2004-05/24/content_1481221.htm, May 24 2004, accessed September 9, 2005.
} 
to take oil off the international market utterly overestimate the coordination and long-term planning of China's energy policy makers. In fact, as China's NOCs are listed on foreign stock markets and increasingly globalized, just as multinational oil companies in the United States, it is not exactly clear whether they still represent only China's national interests.

Similarly, China's closer relationship with major US oil suppliers, such as Canada, Venezuela and Saudi Arabia, partly reflects China's deliberate attempt to court big oil producers and partly reflects the fact that these oil producing countries want to diversify their international markets as well. One can even argue that if China does not make a special effort to court these oil producing countries they will probably turn to China for alternative investment, particularly during a time when their relationship with the United States is in bad shape. For instance, the softwood lumber trade dispute, the follow-up to the September 11 attacks, and other political disputes have soured the US relationship with its three big oil suppliers respectively, Canada, Saudi Arabia, and Venezuela. Therefore, the closer relationship between China and these three countries is to a large extent a derivative of both these oil producers' economic calculus and their reaction to US foreign policies.

China's increased economic activities in Latin American countries, Canada, the Middle East, and elsewhere do not detract from US interests. If trade with China and investments flowing into these countries from China can help these countries to boost their standards of living, they can afford to buy more products from America, thus supporting the US economy and creating more jobs. Moreover, if China invests in oil and energy resources in Latin America when others are not prepared to do so, the PRC is contributing to a larger global pool of available energy. ${ }^{148}$ More importantly, the international oil market is an integrated market, and Chinese oil companies also sell oil on the market. Therefore, Latin American, Canadian, or Middle East oil brought to the surface by Chinese interests probably will end up in the United States the same way that Asian oil brought to the surface by American interests probably will end up in Japan or China. ${ }^{149}$

Finally, the argument that China is trying to use its growing power from expanding overseas energy investment to drive US influence out of certain parts of the world such as Southeast Asia is both speculative and dangerous. First, the support for that claim is based on three assumptions: China's expansion will continue without interruption, the Chinese government has the intention to seek regional hegemony, and countries in Southeast Asia accept China's supremacy. However, none of the three assumptions holds much water. Domestic problems ranging from a fragile banking sector to the yawning income gap, from millions of laid-off workers with no pension plans to millions of rural migrants marching into cities looking for jobs, from power shortages to environmental pollution make China's continuous economic expansion and political rise uncertain at best. Each of these domestic challenges, if not handled properly, could derail China’s economic expansion. Similarly, China's neighboring countries do not like to see Chinese hegemony, and regional integration seems to be a tall order today in East Asia. In fact, regional integration and China's active participation seem to point to another trend that is neglected, which is that China's rise is part of the rise of Asia as a whole. Second, the concern that China is trying to drive out America's influence in certain parts of the world is risky because it can be very misleading for US policy makers. Instead of focusing US policy makers' attention on how the United

\footnotetext{
${ }^{148}$ David Lampton, Testimony at the hearing on "The Role of China in Latin America” in front of Senate Foreign Relations Committee on Western Hemisphere, Peace Corps and Narcotics Affairs, September 20, 2005, 2:30pm, Dirsken Senate Office Building, Room 419.

${ }^{149}$ Ibid.
} 
States should engage with Asia and help many countries there to sort out their problems, that characterization could further isolate the United States from the region and push China to become a US self-induced enemy. Fundamentally, to borrow Professor Lampton's phrase when talking about China's growing investment in Latin America, China is not out principally to weaken the Untied States, it is out to meet the needs of its people. ${ }^{150}$ Nevertheless, in order to avoid inviting suspicion of its intentions, Beijing needs to pay more attention to the international consequences of its active pursuit of energy security through energy diplomacy or overseas investments. In other words, while searching for energy security, Beijing needs to be attentive to the international community's concerns about human rights, democracy, and nonproliferation. Table 14 summarizes China's likely responses to energy insecurity issues and the implications for the United States.

Table 14. Summary of China's responses to its energy insecurity

\begin{tabular}{|c|c|c|}
\hline $\begin{array}{l}\text { Source of China's } \\
\text { energy insecurity }\end{array}$ & China's policies & Implications for the United States \\
\hline Power shortages & $\begin{array}{l}\text { Add new power plants; Energy conservation } \\
\text { campaign; Pass Renewable Energy Law to } \\
\text { expand alternative energy; Expand nuclear } \\
\text { power plants; }\end{array}$ & $\begin{array}{l}\text { Power shortages offer US power } \\
\text { companies some business opportunities; } \\
\text { China might not be able to keep its } \\
\text { nuclear technology and materials safe. }\end{array}$ \\
\hline Environment insecurity & $\begin{array}{l}\text { Promote oil and gas consumption; Expand clean } \\
\text { coal use; Invest in environmental protection; } \\
\text { Establish a Green GDP accounting system }\end{array}$ & $\begin{array}{l}\text { Pollution control in China creates } \\
\text { opportunities for US businesses. }\end{array}$ \\
\hline \multirow[t]{2}{*}{ Oil insecurity } & $\begin{array}{l}\text { To improve availability: Increasing oil } \\
\text { production in the west and offshore; coal } \\
\text { gasification, hydrogen and fuel cell research; } \\
\text { Implemented fuel economy standard; Fuel tax } \\
\text { under consideration } \\
\text { To improve source reliability: Strategic } \\
\text { partnerships with oil exporters; "go out strategy" } \\
\text { (overseas investment); supply diversification } \\
\text { To improve transport reliability: Building a } \\
\text { Sino-Kazakh oil pipeline; To build a Sino- } \\
\text { Russian oil pipeline and a Sino-Myanmar oil } \\
\text { pipeline; Expanding domestic crude tanker fleet; } \\
\text { Building up Chinese navy; Energy diplomacy }\end{array}$ & \multirow[t]{2}{*}{$\begin{array}{l}\text { China's E\&P in East China Sea and South } \\
\text { China Sea might lead to conflict with its } \\
\text { neighboring countries. } \\
\text { China's closer relationships with pariah } \\
\text { states might obstruct US foreign policies } \\
\text { China might engage in arms proliferation } \\
\text { to obtain oil. } \\
\text { China might attempt to use its growing } \\
\text { influence derived from energy investment } \\
\text { to diminish American influence in some } \\
\text { parts of the world } \\
\text { China might take oil off the international } \\
\text { market }\end{array}$} \\
\hline & $\begin{array}{l}\text { To improve affordability: Building four SPRs } \\
\text { bases; Opened oil product futures market; } \\
\text { Increase equity oil and long-term contract } \\
\text { abroad }\end{array}$ & \\
\hline Institutional insecurity & $\begin{array}{l}\text { Established an State Energy LSG and set up a } \\
\text { State Energy Office; Established a SPR office in } \\
\text { charge of building petroleum reserves; To build } \\
\text { an early warning system; } \\
\text { Drafted long term strategy }\end{array}$ & $\begin{array}{l}\text { China's energy market reform provides } \\
\text { US companies with business } \\
\text { opportunities. }\end{array}$ \\
\hline
\end{tabular}

${ }^{150}$ David Lampton, Testimony at the hearing on "The Role of China in Latin America” in front of Senate Foreign Relations Committee on Western Hemisphere, Peace Corps and Narcotics Affairs, September 20, 2005, 2:30pm, Dirsken Senate Office Building, Room 419. 


\subsection{Conclusion}

China's energy insecurity largely originates from the constrained availability, questionable reliability, and uncertain affordability of its oil supplies, and the poor environmental compatibility of its energy consumption. During this time of the country's fast industrialization and urbanization a lot of energy is required but China still consumes energy both intensively and inefficiently. China's risk aversion and poor energy policy making system further magnifies its perceptions of the low availability, reliability and affordability of oil imports, which further compounds its sense of energy insecurity. Distrustful of the market, and suspicious of other major energy players in the international market, the Chinese leadership relies on the state-centered approach, or economic nationalism, rather than a market approach to enhance its energy security. The country lacks not only an energy policy making system that can make and implement sound energy policies, but also an energy market that relies on market prices to allocate energy resources efficiently. As a result of this domestic failure, China has pushed its national flagship energy companies to undertake a global scavenger hunt for energy while muddling along a messy road of energy reform at home. Unfortunately, as a late comer in the international oil market, its experiences so far, particularly those in dealing with asset acquisition in the Caspian Sea region and its attempt to buy Unocal, have only further vindicated the Chinese leadership's belief that the international oil market is not free and China's access to international oil is not guaranteed through the market. Moreover, China's leadership is further convinced that China should focus on areas where western capital is not heavily concentrated or where western influences are weak. With the recent revaluation of Chinese currency and growing economy, China has both the wherewithal and appetite to acquire more oil assets abroad.

However, locking up resources abroad will not provide China with energy security. First, China will not be able to lock up enough oil to meet growing domestic demand. Even after persistent painstaking efforts, by 2020 China will only control about $2 \%$ of global oil production, and it will be consuming $10 \%$ of world's oil. Second, China will find it increasingly difficult to acquire equity oil as it expands its overseas energy investment. More than $77 \%$ of the world's 1.2 trillion barrels in proven oil reserves are controlled by governments that significantly restrict access to international companies. Thus, the political inaccessibility will make China's ambition to control more resources an uphill battle. Finally, in the event of an oil supply shock resulting from conflicts or natural disasters in supplier countries or disruption of SLOCs , it is not clear what the Chinese ownership of resources far from home market can bring China energy security. The reality is that China's oil security is increasingly dependent upon a transparent and well-functioning international oil market, a political accessible environment that encourages international investment to bring more oil onto the international market, and a safe and open passage of SLOCs. All these require cooperation between China and other consumers, and not the least, cooperation with and from the United States.

Both China and the United States stand at a critical juncture of history where China's rise depends on reliable energy supplies which it increasingly imports from abroad and where the growing wealth of the United States is increasingly dependent upon China's success. The Untied States has the ability to shape the way and the outcome of China's search for energy security. Needless to say, if China does not have energy security, the world will not have energy security since there is just too much at stake in China's failure to fuel 1.3 billion people. Therefore, the world, particularly the United States has much at stake in helping China achieve energy security. 
The US help with China's energy security can be conceptualized in the three dimensions we have already discussed, availability, reliability, and affordability. First, the United States can help China improve the availability of its energy by providing technology that can help China use less energy more efficiently and in a more environmentally friendly fashion. Clean coal technology is one example, and US nuclear technology is another one. Second, the US can induce China to adopt a market approach to improve energy security by supporting China's unimpeded access to international oil markets and encouraging liberalization of domestic energy markets. Moreover, the US can also assist China with enhancing its energy policy making capacity. Third, the US can help integrate China into a multilateral energy security system by promoting China's membership in the IEA, encouraging a regional energy emergency system in Asia, facilitating the dispute between China and Japan over the East China Sea gas field, and encouraging China's contribution to stabilizing the Middle East. Any help the United States can offer will improve not only China's energy security, but also the US energy security. After all, energy security is increasingly interdependent and no country can achieve absolute energy security without other countries feeling secure. 


\section{Distribution}

No. of

Copies

\section{ONSITE}

Pacific Northwest National Laboratory
Carol Kessler (40)
BSRC

Dist. 1 



\section{PNWCGS Mission}

Our mission is to address the full range of global security issues by probing the impact of economic, social, institutional and environmental conditions that affect regional stability and global security. We emphasize non-proliferation due to its consequence for global security.

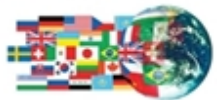

\section{Pacific Northwest Center for Global Security}

For more information, contact:

Carol Kessler, Director

Pacific Northwest Center for Global Security

Pacific Northwest National Laboratory

1100 Dexter Avenue North, Suite 400

Seattle, WA 98109

Phone: 206-528-3222

Fax: 206-528-3225 